\title{
La poliglòssia en la predicació de Vicent Ferrer
}

\author{
Polyglossia in Vicent Ferrer's preaching
}

\author{
Antoni Ferrando Francés \\ antoni.ferrando@uv.es \\ ORCID: 0000-0003-1865-1345
}

Universitat de València

\begin{abstract}
Resum: Un bon nombre dels sermons de Vicent Ferrer ens ha arribat gràcies a les còpies de les reportationes que en feien els estenògrafs que l'acompanyaven en els seus viatges missionals per diversos països de l'Europa occidental (1399-1419). No són, per tant, reproduccions fidels de l'oralitat vicentina, però en reflecteixen els trets bàsics. L'anàlisi crítica d'aquests trets i de les declaracions dels testimonis del procés de canonització de Vicent Ferrer (1453-1454) posen de manifest que el dominic valencià, que en la seua predicació sempre tractà d'aproximar-se lingüísticament als oients, adoptà les parles romànics dels països que va recórrer, ja que sabem que, a més del llatí i de la llengua materna -el català o valencià-, coneixia bé l’aragonés, el castellà, el francés, l’occità i l’italià.
\end{abstract}

Paraules clau: Vicent Ferrer, predicació, segle XV, usos lingüístics, transmissió oral i textual

\begin{abstract}
Many of Vicent Ferrer's sermons have come down to us thanks to copies of the reportationes made by the stenographers who accompanied him on his missionary travels through various countries in Western Europe (1399-1419). They are not, therefore, faithful reproductions of Ferrerian orality, but they do reflect its basic features. The textual examination of these features and the critical analysis of the statements made by the witnesses of the process of canonization of Vicent Ferrer (14531454) show that the Valencian Dominican, who in his preaching always tried to approach his listeners linguistically, adopted the Romance languages of the countries he visited, as we know that, in addition to Latin and to his mother tongue -Catalan or Valencian-, he was fluent in Aragonese, Castilian, French, Occitan and Italian.
\end{abstract}

Keywords: Vicent Ferrer, preaching, 15th century, linguistic uses, oral and textual transmission 


\section{Estat de la qüestió. Objectius}

Ha passat quasi un quart de segle des que vaig abordar el tema del do de llengües de sant Vicent Ferrer en el congrés Sant Vicent Ferrer i el seu temps (1996), organitzat per la Facultat de Teologia Sant Vicent Ferrer, l'Institut de Filologia Valenciana i l'Editorial Saó. El títol de la ponència, «Sant Vicent Ferrer, predicador políglota de l'Europa occidental», prou que reflecteix la tesi que defensava. La vaig sintetitzar en la cloenda de l'article: «fra Vicent Ferrer dominava amb més o menys facilitat les llengües romàniques dels països on predicà, és a dir, el català o valencià, el castellà, l'aragonés, l'occità, el francés i l'italià, i [...] s'adaptava lingüísticament als seus auditoris. No és descartable que, fora del seu país, suplís els seus possibles dèficits lingüístics amb recursos de la llengua pròpia o d'altres» (Ferrando 1997: 94).

Ben mirat, són unes conclusions que han assumit diversos investigadors de l'obra vicentina, però no tots. Em limitaré a adduir els punts de vista de tres dels investigadors que més s'hi han ocupat. Després d'acceptar les conclusions del meu treball de 1996, Josep Perarnau (1999g: 1030) va insistir en els altres factors que facilitaven la comprensió de la predicació vicentina: «Crec que a les consideracions [de Ferrando] relatives a la llengua, calia afegir-hi la didàctica consistent a fer repetir l'esquema bàsic pels assistents i la mímica; tots els sumands, i no sols la dicció del predicador, asseguraven la comprensió de la prèdica». Era una precisió interessant, que superava els objectius del meu treball, limitat a l'estudi de les llengües usades per fra Vicent Ferrer. El segon investigador a considerar és Tomàs Martínez Romero (2002: 116-117), que va constatar que els arguments que jo hi aportava «són suficientment convincents per a creure que sant Vicent degué conèixer poc o molt l'occità, l'aragonès, el castellà, el francès i l'italià, i que faria servir aquestes llengües durant la seua predicació en aquelles terres», bé que en nota a peu de pàgina no deixava d'advertir que els arguments sobre el coneixement de l'italià eren «els més dèbils». Observació pertinent i debilitat argumental explicables, d'una banda, per la pèrdua de la part del procés de canonització de fra Vicent referida a Avinyó, on podrien aparéixer les declaracions dels testimonis procedents del nord d'Itàlia (Esponera 2018: 13), i, d'altra, per l'absència de sermonaris de mestre Vicent específicament consagrats a la seua predicació en terres italianes, tret, en part, del manuscrit de Perúgia. Finalment, el tercer investigador escollit és Philip Daileader, autor de Saint Vincent Ferrer. His world and life (2016), recentment traduit al català com a La vida i el món de sant Vicent Ferrer (2019). Després d'invocar les opinions de Brettle i de Schib en favor de l'ús del valencià en la predicació de fra Vicent i de discutir les conclusions de Pedro Manuel Cátedra i les meues en favor del poliglotisme ferrerià, Daileader afirma: «No puc oferir cap resposta definitiva sobre la qüestió de en quina o quines llengües parlava Vicent quan predicava. Això no obstant, crec que, al final, és probable que Vicent usara preferentment el dialecte valencià del català per tot arreu, i que hi afegira paraules o expressions de la llengua vernacla local, sobretot quan imitava diàlegs». Són punts de vista que mereixen ser considerats atentament.

SCRIPTA, Revista internacional de literatura i cultura medieval i moderna, núm. 16 / desembre 2020 / pp. 71-130 ISSN: 2340-4841 · doi:10.7203/SCRIPTA.16.19213 
En el meu treball de 1996 em vaig poder beneficiar de les darreres aportacions de Pedro Manuel Cátedra (1984; 1994) sobre la predicació castellana de mestre Vicent, les de Josep Perarnau (1985) sobre els sermons del Ms. 477 de la Biblioteca de Catalunya, les de Francisco Gimeno (1992) sobre la possible autografia del nostre dominic (1992) i les d'Adolfo Robles (1995) sobre el sermonari llatí d'Aiora. Ara comptem amb l'edició d'uns quants sermonaris ferrerians inèdits, gràcies, entre altres, al laudatori esforç de Josep Perarnau, Francisco Gimeno, María Luz Mandingorra i Franco Morenzoni, i tenim fàcilment a l'abast l'edició i la traducció castellana de les actes de procés de canonització de mestre Vicent, a cura d'Alfonso Esponera (2018). I, pel que fa a l'estudi concret de la llengua ferreriana, comptarem molt pròximament amb una eina de consulta fonamental: La llengua dels sermons valencians de sant Vicent Ferrer, obra de Jordi Colomina, amb una primera part dedicada a l'estudi gramatical i una segona part, al vocabulari, que completa les aportacions anteriors de Sanchis Guarner (1973), Gret Schib (1977) i Emili Casanova (2008). El meu objectiu ara $i$ ací és doble: per una banda, explotar les dades que ens ofereixen les noves recerques i edicions dels sermons del sant, i, per altra, revisar críticament, a la llum de coneixements nous, la meua aportació de 1996 sobre el tema.

Els arguments sobre el poliglotisme de mestre Vicent Ferrer que vaig adduir llavors es basaven en l'experiència plurilingüe del nostre dominic, en la documentació de l'època, en les dades lingüístiques dels sermonaris vicentins més antics i en els testimonis del procés de canonització. En el llibre Sant Vicent Ferrer en la historiografia, la literatura, l'hagiografia i l'espiritualitat al segle XV (2013b), vaig ampliar el camp d'observació als testimoniatges literaris i cronístics coetanis, bé en llatí, bé en vulgar (català, castellà, francés), del segle XV. Ara em centraré en aquells aspectes dels sermonaris més antics $\mathrm{i}$ de les actes del procés de canonització de mestre Vicent que ens puguen ajudar a confirmar o relativitzar el poliglotisme el nostre predicador. I ho faré combinant la informació que, sobre la llengua de la seua predicació, ens aporten els testimonis de les tres enquestes del procés de canonització que ens han arribat (1453-1454), realitzades a Nàpols, Tolosa i Gwened (Vannes), amb la informació que, sobre la concurrència de llengües, ens forneixen els textos dels sermons localitzats o localitzables en cada una de les respectives àrees geogràfiques. No cal dir que, en la valoració de les declaracions dels testimonis, caldrà adoptar les precaucions metodològiques que, ja el 1924, exigia Mathieu-Maxime Gorce ${ }^{1}$ i que, en la valoració de les dades lingüístiques dels sermons, caldrà relativitzar-ne la fiabilitat absoluta quant a la paternitat vicentina.

\section{Una qüestió prèvia: l'experiència plurilingüe i la praxi lingüística de mestre Vicent}

Per tal d'avaluar adequadament les llengües utilitzades en la predicació vicentina, convindrà recordar, ni que siga esquemàticament, l'experiència plurilingüe del dominic valencià. Vicent Ferrer (ca. 1350-

1 Concretament, Gorce (1924: 25) feia notar que el procés de canonització, tot i ser «une source historique de toute première importance, [...] demande d'être critiquée ligne par ligne dans l'emploi qu'on en fait», car responia a la mentalitat de l’època $i$ al fet que hom pretenia confirmar una tradició hagiogràfica ja formada.

SCRIPTA, Revista internacional de literatura i cultura medieval i moderna, núm. 16 / desembre 2020 / pp. 71-130 ISSN: 2340-4841 · doi:10.7203/SCRIPTA.16.19213 
1419), de família originària de terres gironines, es crià a València, però passà la major part de la seua vida fora de València, allotjat en convents dominicans i en cases de notables, on tenia l'ocasió d'immergir-se en el parlar, els costums i els problemes de cada lloc. Convivint constantment entre membres del seu orde en diversos països de l'Europa occidental amb llengües diferents, degué arribar a tenir una notable competència activa i passiva d'aqueixes llengües, bé que en grau divers. Mirem-ne ara, a grans trets, les principals etapes d'aquest itinerari biogràfic.

Entre els 18 i 26 anys, Vicent Ferrer es formà teològicament a Barcelona i Lleida (1368-1376). Hi degué familiaritzar-se amb el matís oriental del català -que ja devia conéixer perquè el pare era de Palamós (Baix Empordà)-, pogué constatar que la varietat occidental del català era quasi idèntica a la del català de València, perfeccionà el llatí i s'ensinistrà en hebreu. Sembla que completà la formació teològica a Tolosa, probablement entre 1376 i 1378 (Riquer 1964b: 201). Si fos així, allí ja hauria tingut l'oportunitat de familiaritzar-se amb l'occità de la població en general i possiblement amb el francés de les elits dominants.

El 1381, acompanyà el cardenal aragonés Pedro Martínez de Luna en la seua missió diplomàtica per Castella i Aragó en favor de la causa avinyonesa. Ho tornarà a fer el 1390. Degué acostumarse així al castellà i a l'aragonés. Probablement ja comprenia l'aragonés des dels anys d'infantesa i adolescència a València a causa d'un constant flux immigratori procedent d'Aragó. ${ }^{2}$

La possible coneixença del francés per part de fra Vicent podria haver influir en el fet que la infanta francòfona Violant de Bar, esposa de l'infant Joan i futura reina de la Corona d'Aragó, escollís fra Vicent com a confessor. Aquest nomenament fou vigent entre 1382 i 1385 (Riera 2013: 407408). En canvi, no està documentat que fra Vicent fos confessor també de l'aragonesòfona Maria de Luna, senyora de Sogorb, esposa de l'infant Martí (1372), el futur rei Martí l'Humà. Tots dos s'adreçaven en aragonés a la ciutat de Sogorb (Tomás 2020: 184). En tot cas, sabem que, a petició dels infants Martí i Maria de Luna, fra Vicent predicà a Sogorb la quaresma de 1386. Probablement ho va fer en aragonés. Si a això afegim el fet que fra Vicent fou conseller i almoiner del rei Martí, ens podem explicar millor els seus contactes freqüents amb la cort reial, on es manejaven tant el català com l'aragonés. Un moment singular dels contactes de mestre Vicent amb l'aragonés fou arran de les sessions del Compromís de Casp (1412), on hagué de conviure més de tres mesos amb els compromissaris aragonesos. El nostre predicador havia acudit a Casp després de més de catorze mesos de contacte permanent amb el castellà en terres del regne de Castella.

\footnotetext{
2 Cal recordar que l'aragonés era també la llengua majoritària d'una dotzena de poblacions cristianes de l'interior del regne de València, com ara Sogorb i, per tant, una llengua en contacte freqüent amb el català de València. Llavors la llengua aragonesa conservava la seua fesomia pròpia i la condició de llengua oficial del regne d'Aragó i de llengua cooficial en l'àmbit de l'administració reial de la Corona d'Aragó. Tots els secretaris de la Cancelleria reial devien conéixer el llatí, el català i l'aragonés. Francho Nagore (Giralt \& Nagore 2000: 69-123) ens acaba d'oferir una bona descripció de l'aragonés medieval en textos no literaris i un mapa (p. 73) de la distribució geogràfica dels dialectes aragonesos medievals, entre els quals l’«aragonés de las Serranías Ibéricas» o parlar serrà.
} 
El 1395, mestre Vicent és cridat a Avinyó pel papa Benet XIII. Hi passà quatre anys com a confessor del papa, penitenciari apostòlic i mestre del Sacre Palau (1395-1399). Els tres primers anys, convisqué amb els curials pontificis, però des del 1398 residí permanentment en el convent dominicà de la ciutat, en un context occitanòfon. En la cúria papal predominaven els occitans i francesos, però també n’hi havia d'italians, ja que Sicília, Sardenya, Nàpols i moltes ciutats del nord d'Itàlia eren d'obediència avinyonesa. ${ }^{3}$ Un dels testimonis en l'enquesta napolitana del procés de canonització de mestre Vicent, Joan Soler, fa referència a la presència de curials de moltes llengües en la cort de Benet XIII a Gènova (Esponera 2018: 598). A la cort papal d'Avinyó, Vicent Ferrer degué millorar els seus coneixements de francés, es familiaritzà amb els matisos orientals de l'occità, pogué entrar en contacte amb el francoprovençal o arpità de Savoia i dels països veïns ${ }^{4}$ i tingué una excel lent oportunitat per a ensinistrar-se en l'italià. $\mathrm{Al}$ convent dominicà d'Avinyó, on degué viure una situació d'immersió lingüística provençal, conegué el seu gran col laborador i futur reportador i compilador dels seus sermons, fra Antoni Anglada.

És amb tot aquest bagatge plurilingüe que fra Vicent inicià, el 1399, la seua dedicació sistemàtica a la predicació itinerant per diversos països de l'Europa occidental, com a legat a latere Christi, sense penetrar en terres de llengua no romànica. Així, a Bretanya a penes ultrapassà les regions bilingües franco-bretones, ja que devia ser conscient que era inviable de fer-se comprendre des del punt de vista de la comunicació verbal.

Abans d'entrar en cada ciutat on anava, fra Vicent procurava informar-se de les circumstàncies socials i religioses amb què s'hi havia de trobar. Sempre es va fer acompanyar de col laboradors de molts diversos indrets, que el devien introduir en els parlars respectius. Així, a més del ja esmentat Anglada, fra Vicent comptà, entre altres, amb els valencians Joan Gilabert Jofre, Joan d'Alcoi i Pere de Moya (aquests dos probablement de llengua castellana o aragonesa), amb els catalans Jofre de Blanes, Pere Cerdà, Antoni Fuster i Pere de Queralt, amb els aragonesos Juan García i Fernando Ximén de Urrea, amb l'alvernés Blasi d'Alvèrnia, amb l'italià Antonio D'Auria, amb el francoprovençal Joan Placentis i amb mestre Philippus (potser francés?), el seu capellà secret (Diago 1600; García Martínez 2006: 204-207).

Dit això, convé adoptar una precaució metodològica quan parlem de les sis llengües romàniques que Vicent Ferrer devia dominar: el català, el castellà, l'aragonés, l'occità, l'italià i el francés. Aquestes

3 Entre els eclesiàstics italians presents a Avinyó de rang més elevat hi havia els cardenals napolitans Leonardo Rossi de Giffone, superior general de l'orde franciscà, Tomàs d'Amanatis, arquebisbe de Nàpols, i Bonifaci d'Amanatis, notari apostòlic, i el llombard Joan de Placentinis (Eubel 1913: 28-30).

4 Francoprovençal i arpità són denominacions recents d'una llengua romànica pròpia de la Savoia, el Lionés i d’algunes regions limítrofes del Franc-Comtat i del Delfinat, que comparteix trets semblants al francés i d'altres a l'occità. És una llengua que no ha gaudit mai d'un estatus consolidat de llengua administrativa i cortesana. De fet, la cort del ducat de Savoia ja adoptà el francés des de la darreria del segle XIV (Stich 2005: 173-191). 
denominacions corresponen al concepte actual de què entenem per llengua, però si ens retrotraiem a l'època medieval cadascuna d'aquestes llengües recobria una varietat de manifestacions diatòpiques molt pronunciades fins al punt que algunes d'elles eren considerades llengües (com ara el llombard). Sota el nom actual d'occità es comprenien parlars molt diferents (llenguadocià, provençal, gascó, llemosí, alvernés), que, contràriament a l'arpità o francoprovençal, compartien una rica tradició literària i administrativa. La llengua catalana solia rebre popularment el nom de valencià al regne de València des del primer terç del segle XIV. Tots dos noms hi eren usats entre els valencians fins als anys seixanta del segle XV (Ferrando 1980; Ferrando \& Nicolás 2011: 103-105; Ferrando 2013b). No hi havia pràcticament cap diferència entre el català de la Catalunya occidental i el català de València (parlars filològicament coneguts com a català occidental). El mateix fra Vicent ho reconeix indirectament quan proclama en un sermó predicat a Lleida el 15 de març de 1414, que Lleida, capital de la Catalunya occidental, «mater est Valencie» (Robles 1995: 250), sens dubte en referència al fet que la capital del Segre hauria fornit el contingent més nombrós dels repobladors de la ciutat de València al segle XIII i, en conseqüència, hauria exportat a València la seua parla (Ferrando 1989). ${ }^{5}$ Les diferències entre el català de la Catalunya oriental i el de Mallorca (parlars filològicament coneguts com a català oriental) eren escasses.

Després de conéixer l'experiència plurilingüe de fra Vicent, podem avançar algunes hipòtesis sobre les seues competències lingüístiques, sempre dins de la provisionalitat que imposa l'escassa documentació de què disposem. El parlar matern de fra Vicent era el valencià, però el nostre dominic també devia conéixer i dominar prou bé els principals trets del parlar oriental i del parlar occidental de Catalunya, on residí uns quants anys. En canvi, devia conéixer poc el parlar de Mallorca, illa on sojornà menys de cinc mesos. En conseqüència, fra Vicent es podia adaptar perfectament tant a la modalitat occidental com a la modalitat oriental de la llengua catalana. Si jutgem per la presència de petges aragoneses en els sermonaris vicentins en llatí $i$ fins i tot en els sermonaris castellans, hem de concloure que el nostre predicador devia tenir un bon domini de la llengua aragonesa, prou millor que no de la castellana. Tanmateix, l'autor anònim de la Relación a Fernando de Antequera no observà cap estranyesa en el castellà en què predicava fra Vicent a Castella.

Gràcies a la llarga estada a Avinyó, fra Vicent devia dominar bé el provençal. En canvi, devia conéixer poc el parlar occità de l'Alvèrnia, on només sojornà durant un curt període de temps. En tot cas, tots els parlars occitans eren molt pròxims al català. No sabem fins a quin punt mestre Vicent arribà a conéixer l'arpità a Avinyó, ciutat pròxima a la Savoia. En tot cas, hi estigué en contacte en una primera missió en terres arpitanes entre el 1402 i el 1404, centrada a l'antic ducat de Savoia, i en una segona el 1418, centrada a Lió i regions dels voltants.

$5 \mathrm{El}$ testimoniatge de fra Vicent s’afegeix així a les nombroses manifestacions d'una llegenda històrica, de base real, àmpliament difosa a totes les terres de la Corona d'Aragó, inclòs Nàpols, des de començament del segle XV, que analitze en un article dedicat expressament a l'estudi de la formació històrica del català de València (Ferrando 1989 [1986]). 
Sembla que fra Vicent dominava l'italià culte, però aquest italià només li podia servir parcialment quan predicava a Gènova o a la Llombardia, ja que havia de modular-lo si volia aproximar-se als parlars de la Itàlia septentrional, pròxims a l'occità i prou diferents del toscà, base de l'italià culte.

Encara que la major part dels sermons vicentins ens han arribat en llatí, la presència de petges romàniques i les referències a situacions locals suggereixen la voluntat del nostre predicador d'aproximar-se a la seua audiència i, doncs, l'ús del vulgar en la major part de les ocasions. Franco Morenzoni (2008: 516) ha recordat que fra Bernardí de Siena mirava d'aprendre elements del parlar de la regió on volia predicar abans d'anar-hi. Com tindrem ocasió de comentar més endavant, aquesta fou també l'actitud de fra Vicent: només cal recordar els seus comentaris lingüístics a propòsit de la parla dels sarraïns en un sermó que predicà a Múrcia el gener de 1411 o els que feu a propòsit de la parla dels serrans aragonesos en un altre sermó predicat en aquelles terres el setembre de 1412. Fra Vicent era ben conscient de la diversitat lingüística i nacional de la Romània. Recordem aquella coneguda frase seua: «Digau: ¿en què coneix hom una persona de qual terra és? En lo lenguatge, car si vós parlau ab hom estrany, en la lengua conexereu de qual terra és: si parle català, oo, català és; si francés, francés, etc., car la lengua done a conéixer la persona de qual terra és» (Schib 1984: 178). I sovint evocava els noms dels països on era o havia estat: Aragó, Catalunya, Regne de València, Savoia, Llombardia, Gènova, Monferrat, etc.

Tot i amb això, els oients dels sermons de fra Vicent de fora de l'àmbit lingüístic català devien percebre que la llengua del predicador no era ben bé la seua, per molts coneixements lingüístics que aquest tingués de la llengua de cada territori i per moltes adaptacions dialectals que en fes en les seues predicacions. Aquesta percepció és la que expressaren de diferent manera alguns testimonis del procés de canonització i la que degueren explotar els enquestadors del procés per a justificar el miracle que fra Vicent parlava en la seua llengua materna i que, tanmateix, era comprés per tothom. De tota manera, no hem d'oblidar que en els sermons medievals pesava molt més la comunicació gestual que no la verbal, i els de fra Vicent no en són l'excepció.

En els sermons vicentins predicats més enllà de l'àmbit lingüístic català s'observen paraules i expressions alienes a la llengua del país: aragonesismes sobretot en la predicació castellana, tal com ha demostrat Pedro Manuel Cátedra (1994), però també en la predicació llenguadociana, algun catalanisme en la predicació occitana i francesa, i molts catalanismes, castellanismes i occitanismes en les versions llatines. La presència d'aquests al loglotismes s'ha explicat sovint com a expressió de l'espontaneïtat de la situació comunicativa o com un deliberat recurs oratori de mestre Vicent. Però generalment són petges del procés de col lació de dos o més antígrafs, que els copistes més antics van deixar.

El manteniment de mots romànics en català, occità, francés, castellà o aragonés en els anuncis de la divisio thematis dels sermons vicentins és un indici prou segur que foren predicats en una d'aquestes llengües, sobretot quan aquests mateixos al loglotismes són reiterats en l'exposició dels subtemes. En tot cas, el plurilingüisme reflectit en els sermonaris vicentins més primitius revela que mestre Vicent Ferrer s'adaptava als diferents escenaris lingüístics. 
Una altra qüestió a tenir present a l'hora d'estudiar la llengua «catalana o valenciana» dels sermons vicentins és que la que ens ha arribat ja va ser objecte de selecció, regularització i ordenació per part de redactors o copistes professionals, en un grau de fidelitat lingüística a les reportacions originals difícil de precisar. Així, Sanchis Guarner (1973, I: 31) constatà que els sermonaris valencians de l'Arxiu de la Catedral de València (ACV) presenten alguns trets dialectals del Maestrat, Baix Aragó i regió de Lleida que no es poden atribuir a fra Vicent. Tomàs Martínez (2019) i Francisco Gimeno (2019) han estudiat el procés de transformació de l'estadi lingüístic dels reportadors a l'estadi lingüístic dels redactors i copistes. Martínez ho ha fet a propòsit del manuscrit de la Quaresma valenciana de 1413; Gimeno, a propòsit del Ms. 610 de la Bibliothèque Municipale d'Avinyó. Les precaucions metodològiques per a distingir en la mesura del possible entre un estadi i l'altre, una qüestió complexa, són requisits indispensables per a acostar-nos a la llengua de mestre Vicent. Ara bé, els interrogants que susciten els problemes de transmissió no invaliden la imatge autèntica de la mena de llengua que es desprén dels sermonaris vicentins, que se situa entre el registre col loquial d'un gran comunicador de masses i el registre acurat propi d'una persona amb molt bona formació teològica, com fou al mateix temps mestre Vicent Ferrer.

\section{Els sermonaris com a font per a determinar la llengua de la predicació vicentina}

Els sermons de mestre Vicent que coneixem són fruit de la tasca dels reportadors, que recollien en vulgar o en llatí els aspectes bàsics de la seua predicació. Els sermonaris més antics en llengua catalana i en llengua castellana de fra Vicent ens acosten a la llengua en què foren predicats. Els reportadors que passen a net les notes preses directament dels sermons o els amanuenses que en copien les transcripcions sempre n’alteren, deliberadament o no, alguns trets lingüístics i en redueixen la informació, però no fins al punt de desfigurar la llengua del predicador. Gràcies a les còpies de les reportacions tenim un coneixement imperfecte, però fidedigne, de la llengua del nostre predicador. L'acumulació, la convergència i la coherència de les solucions lingüístiques dels sermonaris ferrerians més primitius confirmen l'autenticitat bàsica de la llengua de mestre Vicent tant en català com en castellà. En canvi, els sermons que es tradueixen al llatí per fixar-ne l'estructura, dotar-los de formalitat i fer-los assequibles a predicadors d'altres llengües perden una bona part de l'espontaneïtat i de l'expressivitat característiques del discurs oral. Ja s'han estudiat molts aspectes textuals i estilístics dels sermons de fra Vicent en català i en castellà. ${ }^{6}$ Ara ens interessen les petges romàniques presents en les traduccions llatines dels seus sermons que ens puguen il luminar sobre la llengua o les llengües usades per fra Vicent en els seus sermons.

6 Per a l'estudi de l'estructura textual dels sermons vicentins són imprescindibles tots els treballs de Perarnau sobre els sermons del nostre predicador que figuren en la bibliografia final d'aquest article. Per als problemes de la transformació de l'oralitat en escriptura i de la transmissió textual dels sermonaris vicentins convé consultar Cátedra (1994), García Martínez (2006), Gimeno (2019) i Martínez Romero (2019). Per a l'estudi de l'estructura literària, són ben útils les introduccions de Chabàs (1903), Fuster (1955) i Martínez Romero (2002). Daileader (2019: 297-310) consagra un capítol als problemes que presenta l'estudi dels sermons de fra Vicent. 
Ben sovint, els sermons vicentins s'inicien, una vegada explicitat el tema, amb l'anunci de la divisio thematis, generalment expressada en forma rimada com a recurs mnemotècnic. Ja s'ha dit que els traductors dels sermons al llatí conserven a vegades la divisio thematis en vulgar, si aquesta era la llengua de la redacció original, sobretot quan l'enunciat adopta unes formulacions llatinitzants pròximes al llatí, que fan innecessària la traducció. Heus ací com presenta l'anunci de la divisio thematis el sermó núm. 103 del Ms. 477 del Convent dominicà de Perúgia (o Perusa, en la tradició onomàstica catalana), que cite segons l'edició de Gimeno i de Mandingorra (2006):

\author{
Obediència general \\ Penitència sacramental \\ Paciència virtual \\ Benivolència cordial \\ Benificència liberal \\ Diligencia spiritual \\ Perseverància final
}

Altres vegades, els traductors mantenen la divisio thematis en vulgar per la dificultat de preservar bé en llatí els conceptes o la rima original. Així es podria explicar, per exemple, la conservació del vulgar en la divisio en el sermó núm. 419 de l’esmentat manuscrit de Perúgia:

\footnotetext{
Menysprehar est setgle terrenal

Escapar del greuge general

Empetrar lo regne celestial
}

Les raons mnemotècniques són les que ajuden a explicar els casos d'enginyeria lingüística en la divisio thematis que observem, per exemple, en el sermó núm. 306 d'aquest mateix manuscrit, on les riqueses del món es presenten com:
Maculose brutalment
Enganose falsament
Infructuose certament
Periculose grandament

En alguna ocasió, els traductors al llatí dels anuncis de la divisio thematis en vulgar han afegit al marge del text traduït les formulacions originals de mestre Vicent Ferrer o d'un altre antígraf. Aquestes informacions dels copistes ens permeten constatar la dificultat de mantenir en llatí la rima de la versió original.

Gràcies a la reiteració literal de les paraules romàniques de la divisio thematis a l'inici de l'explicació en llatí de cada un dels subtemes, podem deduir, amb un alt grau de probabilitat, la llengua en què foren concebuts, i molt probablement predicats, els sermons. Encara són més determinants en aquest sentit les paraules o les expressions preservades en vulgar al si de l'exposició dels subtemes. 
Generalment, es conserven en vulgar els termes usats per fra Vicent, quan resulta complicat de traduir-los en llatí o quan es vol preservar els conceptes i l'estil directe de les expressions i les exclamacions del nostre predicador. Així, si el traductor del manuscrit de l'Arxiu Parroquial d'Aiora conserva en vulgar el sintagma «a les Maries» en la frase «apparauit a les Maries» (Robles 1995: 372), deu ser perquè li resultava difícil traslladar-lo al llatí sense perdre'n l'expressivitat de la llengua col loquial o simplement perquè volia reflectir amb precisió l'oralitat vicentina.

Una informació molt rica en aquest aspecte ens l'ofereix el manuscrit 610 de la Bibliothèque Municipale d'Avinyó, amb 130 sermons de fra Vicent redactats en llatí, que ara coneixem gràcies a l'edició de Francisco Gimeno i María Luz Mandingorra (2019). Sabem que aquest manuscrit, compilat entre 1414 i 1415, recull, entre altres sermons de mestre Vicent, la seua predicació mallorquina entre setembre de 1413 i gener de 1414, generalment amb indicació del lloc de la predicació i de la celebració litúrgica corresponent (sermons 33 a 85), i així mateix sabem que el propietari i el compilador del manuscrit fou el provençal fra Antoni Anglada, que també en degué ser el reportador, almenys de la majoria dels sermons. ${ }^{7}$ No se'n coneix ni la cronologia ni la ubicació dels altres sermons, llevat del sermó núm. 23, predicat «in orto Barchinone», i del sermó núm. 430, predicat a Alcanyís. Però tots són sermons molt pròxims a la predicació directa de fra Vicent, que presenten catalanismes, occitanismes, aragonesismes i castellanismes.

Amb tots aquests ingredients ja podem explicar-nos millor alguns hibridismes lingüístics en els anuncis de la divisio thematis $i$ la presència de termes $i$ expressions catalanes, occitanes $i$ aragoneses o castellanes en els resums dels sermons. Així, al sermó 74 observem l'ús del llatí, del català i de l'occità en el breu anunci de la divisio thematis:

Primo, lo luoc en què stam,

Secundo, los enemics dels quals nos gardam,

Tertio, lo salari o loguier que speram.

No cal dir que, en un sermó predicat a Mallorca, com és el cas, els occitanismes són poc explicables, si no els atribuïm al reportador. Ara bé, en el sermonari apareixen nombroses paraules o expressions en català com «gara de vento temptationis», «entre dos platells de argento», «plenum de serpens grapans», «quando trona lo ventre», «tant per tant», «semetipsum exinanivit, id est se desfrassà», "procuratorem seu piquaplat》, «loqui a tort et través», «cor enviscat», «prostrando se totum bocaterrosa», «dolorem stomachi, dolors e torsons», «aquam coctam cum sucra rosat», «vendebat plus per espera», etc., que reflecteixen les paraules originals de fra Vicent. Aquesta fidelitat a la llengua del predicador es manifesta més

7 Antoni Anglada, que havia conviscut amb el nostre predicador al convent dominicà d'Avinyó, formà part del seu seguici i recorregué amb ell no sols Mallorca, sinó també Catalunya, València i Aragó. Així, ens consta que fra Vicent i fra Antoni eren junts a Saragossa l'1 de juliol de 1415, abans d'emprendre viatge a Perpinyà (Gimeno \& Mandingorra 2019: 15). En la missió mallorquina, potser induïda pel rei Ferran I, també acompanyaren fra Vicent el dominicà aragonés Juan García i el cartoixà francoprovençal Joan Placentis, ambdós testimonis del procés de canonització de mestre Vicent (Rosselló 2018). 
clarament quan s'hi reprodueixen algunes preferències lèxiques valencianes, ${ }^{8}$ com «cana de adacza» (sermó núm. 109) o «entropessam in inferno» (núm. 128), en lloc dels sinònims més generals panís i ensopegam, respectivament, que difícilment podríem imputar a fra Antoni Anglada. Aquestes preferències lexicals valencianes, que suggereixen la ubicació valenciana dels sermons núms. 109 i 128, són, però, excepcionals. La norma és l'ús del català general, amb mots com ara encepegar/ ensopegar, esfondrar, allenegar, gelós, que en el català de València de l'època coexistien amb les formes més locals entropessar, afonar, esvarar, zelós, respectivament. La reproducció de frases més llargues en català, com «flama quasi de foc de solpre escur» (núm. 6) o com «ni obrir obradors, ni ferrar, ni barbejar, etc., ni fareu causes» (núm. 10), apunta més aïna a la dificultat de trobar, en el moment de l'escripturació, una solució traductològica satisfactòria.

La presència, al llarg de tot el sermonari, d'occitanismes gràfics i morfològics com prenhat, abellha, gargantiera, langotiers, deniers, paüc a paüc, etc., i fins i tot de frases com «ni baysar-se a far pas» (núm. 5), «camp claus de batalha» (núm. 15), «de belas cambas» (núm. 107), és més freqüent del que hom esperaria d'un reportador familiaritzat ja amb el català de fra Vicent. És dificil de dilucidar si són fruit directe del seu treball de reportador o si són més aïna fruit del seu treball de compiladortraductor, que hauria tingut al davant un text vicentí predicat uns anys abans en occità. Sabem que Anglada havia acompanyat fra Vicent en les seues predicacions per terres occitanes. És poc explicable que pose en occità uns termes molt semblants al català, si no té davant un antígraf en occità. Ho suggereix si més no la presència de frases en occità. Anglada mateix confessa que ha examinat un «libro qui incipit 'Ecce rex tuus', ubi sunt reportationes magistri Vincentii» (Gimeno \& Mandingorra 2019: 8). I sabem que la principal preocupació dels compiladors era oferir una seqüenciació litúrgica dels sermons, que habitualment només es podia aconseguir recorrent a diverses fonts.

Que Anglada potser ha consultat més d'un antígraf ho suggereix el fet que, des del començament fins al final del manuscrit, trobem exemples de castellanismes o aragonesismes, com ara «metahls fundidos» (núm. 2) o «doctrina que de part de Dios» (núm. 86). Com que Anglada també acompanyà fra Vicent en terres aragoneses, sembla lògic deduir que devia conservar materials procedents d'aquesta predicació i, doncs, que en guardava les reportacions.

En conseqüència, els sermons del manuscrit d'Avinyó - no debades guardat a la ciutat d'Avinyó- no semblen meres traduccions de les reportacions originals d'Anglada, sinó reelaboracions fetes per ell a la vista de diversos antígrafs. Així i tot, l'examen del manuscrit permet constatar que som davant un text primitiu i poc treballat, que, malgrat la traducció al llatí, preserva prou bé l'expressivitat

8 Entenem per preferències lèxiques valencianes aquells mots (lexemes i variants formals) de la llengua catalana que, almenys des de principi del segle XV, començaren a ser-hi preferides davant d'altres opcions sinonímiques, també usades però generalment amb menor freqüència. Moltes de les preferències lèxiques valencianes no es poden considerar encara dialectalismes, ja que es poden documentar coetàniament en altres territoris de l'àmbit lingüístic català i eren a València mots literaris, que veiem usats en les grans obres literàries del segle XV, com el Curial e Güelfa, atribuïda a Enyego d'Àvalos, el Tirant lo Blanc, de Joanot Martorell, o l'Espill, de Jaume Roig. Vegeu nota 40. 
espontània de la predicació vicentina, gràcies al fet que el traductor i copista en fou també el reportador.

Aquest és també el cas d'un altre manuscrit llatí, guardat al Reial Col legi del Corpus Christi, de València, més conegut com a manuscrit del Patriarca, que recull la predicació castellana de fra Vicent. Però ací les petges romàniques són en català i en un castellà amb aragonesismes. El manuscrit podria ser de 1411-1412 i el copista principal fou fra Joan d'Alcoi, col laborador del nostre dominic, que podria ser «aragonès o de la zona castellana del País Valencià», ja que «escriu frases en castellà, però sempre amb grafia catalana, per exemple, usant sempre la 'ny' quan ha de grafiar el so corresponent a aquesta lletra» (Perarnau 1999d: 401). En donar compte dels deixebles de fra Vicent i sens dubte després de consultar el manuscrit del Patriarca, Francisco Diago (1600: 247) va fer notar que, quan el dominicà valencià missionava a Chinchilla, el 1411, delegà en dos dels seus acompanyants, els també dominicans Joan d'Alcoi i Pere de Moya, que s'ocupessen de fer-hi els sermons vespertins. Òbviament, fra Joan i fra Pere, que ben bé podrien ser de llengua materna castellana o aragonesa, hi van predicar en castellà. Fra Joan i fra Pere no sols van compartir amb fra Vicent la predicació en moltes poblacions castellanes, sinó que degueren ser els seus assessors lingüístics en castellà. Ben probablement, fra Pere també fou reportador dels sermons de fra Vicent. Independent de l'ús esporàdic d'algun terme o d'alguna expressió en català que en pogués fer fra Vicent -no hi ha constància documental que això hagués ocorregut mai-, la presència d'aquests catalanismes en el manuscrit del Patriarca pot tenir a veure amb els materials previs que manejaven tots tres per a preparar la predicació.

Ja hem dit que els manuscrits d'Avinyó i del Patriarca són interessants des del punt de vista lingüístic, perquè són coetanis del nostre predicador, van ser confegits per col laboradors seus i reflecteixen molts trets directes de l'oralitat vicentina. No passa el mateix amb la major part dels manuscrits pòstums, en què els copistes ja no són els reportadors. Concretament, en el cas dels manuscrits llatins pòstums, les petges romàniques semblen fruit mecànic del treball de còpia. En una situació intermèdia es troben els quatre volums de les Reportationes sermonum Reverendissimi Magistri Vincentii Ferrarii, predicatoris finis mundi, de l'ACV, en llengua catalana, datables ca. 1428. Com veurem després, el compilador degué basar-se en antígrafs molt pròxims a les reportacions directes dels sermons.

Un dels sermonaris ferrerians pòstums en llatí que ofereix més interés des del punt de vista de la preservació de romancismes i de la visibilització del treball d'aplec de diversos antígrafs és el manuscrit d'Aiora, de 1435 (Robles 1995), que copia sermons de diversa procedència geogràfica i de diversa naturalesa lingüística, com són els vint-i-un sermons corresponents a la quaresma de 1414 predicada a Lleida (Robles 1995: 157-329), o els set corresponents a la quaresma valenciana de 1413 (Robles 1995: 333-394). Els sermons lleidatans en llatí del manuscrit d'Aiora, predicats en català, a penes presenten petges de la llengua original. En canvi, els sermons de la quaresma valenciana i dels altres temps litúrgics que s'hi arrepleguen mostren un bon nombre de petges romàniques, tant en català com en castellà o aragonés. És un indici que el compilador del manuscrit 
degué comptar amb almenys un antígraf castellà o aragonés, a més d'un de català, i que és a aquest antígraf castellà o aragonés que hauríem d'imputar la preservació dels castellanismes o aragonesismes, i no al copista.

L'interés lingüístic del manuscrit d'Aiora s'acreix quan observem que arreplega versions llatines de sermons en català copiats al Ms. 273 de l'ACV, actualment titulat Sermons de Sant Vicent Ferrer. Quaresma de 1413 (Sanchis Sivera 1927; Sanchis Guarner 1973: I i II), datable cap a 1458. La col lació textual entre ambdós manuscrits permet deduir que el text llatí del manuscrit d'Aiora no és una traducció de la versió catalana reproduïda en l'esmentat Ms. 273, sinó d'una altra versió en llengua catalana lleugerament diferent. Les discrepàncies no són sols de detall, sinó també de fons. Així, mentre al començament de la versió llatina del sermó de Dijous Sant de 1413, predicat el 20 d'abril, llegim que Jesús, en celebrar la Cena, «voluit accipere cum Discipulis suis, et hoc per bon comiat» (Robles 1995: 333), en la versió catalana del mateix sermó del Ms. 273 llegim únicament que Jesús la «volc fer ab los seus sants deixebles» (Sanchis Guarner 1973: II, 163). En canvi, el fragment llatí del mateix sermó dedicat a considerar l'«oblacionem perpetualem» (Robles 1995: 339-340) no solament conté una informació superior al 30\% respecte del fragment català corresponent del Ms. 273 (Sanchis Guarner 1973: II, 167-168), sinó que inclou una frase en castellà («quia antiquitus sutzio era el sacrifficio»), absent en el text català. La qual cosa confirma que el copista de la versió del manuscrit d'Aiora, a més d'un antígraf en castellà o aragonés, devia comptar amb una versió catalana diferent de la de l'esmentat Ms. 273. ${ }^{\text {' }}$

A mesura que transcorre el temps, els sermonaris vicentins, ja convertits en fonts llatines per a ús dels predicadors en general, eliminen els aspectes més relacionables amb l'oralitat i, doncs, amb la llengua pròpia del nostre dominicà, $i$ també tota aquesta mena d'incrustacions romàniques, que remeten als estadis més pròxims a la gènesi de les primeres redaccions de les reportacions dels sermons ferrerians.

L'examen crític de les paraules i frases que apareixen en un determinat tipus de romanç en els sermonaris llatins de fra Vicent i la col lació entre manuscrits que porten sermons amb el mateix tema ens ajuden no sols a determinar, hipotèticament, en quina llengua foren predicats, sinó també

9 El sermonari d'Aiora presenta molts exemples de paraules i expressions bé en català («caldera plenam plumbi regalat», p. 386), bé en castellà («murciélagos o muçuelos», p. 390) o bé en un llenguatge híbrid en la divisio thematis («obrando almoynas fraternals», p. 378). Aquests mateixos exemples es troben íntegrament en català en la versió del mateix sermó que recull el manuscrit de la Quaresma valenciana de 1413 (Sanchis Sivera 1927): «paella gran plena de plom regalat» (p. 321), «muçols o rates penades» (p. 325) i «obrant almoynes fraternals» (p. 315). La conclusió que n’extraiem és que el copista devia ser un castellanoparlant que no sempre entenia bé el català que copiava. Podem explicar-nos que deixés en català alguns refranys, sobretot si eren rimats («a hòmens folls / no ls cal campanetes al coll», p. 381), però és difícil explicar que traduís «poble menut» per «los menudos» («Et populus, los menudos, volebant Iesum», p. 352), o que anunciés en castellà o aragonés el pla de divisió del sermó del Divendres Sant («Los seys punctos son aquestos», p. 344) i que hi barregés petges en català i en castellà. Potser no és cap casualitat que el manuscrit haja estat conservat en l'arxiu parroquial de la capital d'una comarca històricament castellanoparlant, ara coneguda com la Vall de Cofrents.

SCRIPTA, Revista internacional de literatura i cultura medieval i moderna, núm. 16 / desembre 2020 / pp. 71-130 ISSN: 2340-4841 ·doi:10.7203/SCRIPTA.16.19213 
a discernir, sempre aproximadament, entre l'oralitat vicentina i les aportacions pròpies dels copistes. Amb tot, caldrà tenir en compte que fins els manuscrits més primitius del sermons vicentins son reelaboracions fetes a partir d'unes reportacions que no ens han arribat. Com ja va advertir Chabàs (1903: 1) a propòsit dels sermonaris vicentins de la Seu de València, aquestes redaccions no són de l'autor, però són «notas auténticas» dels sermons que realment predicà. Molt probablement, mestre Vicent va vigilar moltes de les transcripcions que feien els seus estenògrafs. Aquest podria ser el cas de la predicació mallorquina continguda en el manuscrit d'Avinyó (Gimeno \& Mandingorra 2019: 15-20).

Per a l'estudi de la llengua els sermons de fra Vicent cal tenir en compte, si és possible, la localització i la cronologia de cada un d'ells. Desgraciadament, les informacions que en posseïm són escasses i, sovint, problemàtiques, ja que els compiladors dels sermons vicentins procuraven elaborar uns sermonaris d'acord amb l'any litúrgic i, quan calia o els interessava, extreien textos de diversos antígrafs per a completar-ne les mancances. En conseqüència, només s'ha pogut determinar hipotèticament i amb les precaucions escaients la localització i la cronologia d'algunes seccions dels sermonaris quan s'ha posat a contribució un conjunt de dades internes (citacions, remissions, datacions, lèxic, onomàstica, etc.) i externes (calendari litúrgic dels anys de la predicació, documents, itineraris, etc.) que permeten produir una argumentació sòlida, tal com han fet, entre altres, sobretot Perarnau i Riquer. En aquest estudi, crec que he pogut fer també alguna aportació en aquest sentit.

\section{4. Àrees geogràfiques i adscripció lingüística en les enquestes del procés de canonització}

Una de les finalitats de tot procés de canonització és aconseguir el reconeixement de la santedat de la persona que es vol elevar als altars mitjançant proves testificals sobre els miracles i les virtuts extraordinàries que se li atribueixen. En el cas de mestre Vicent, es va optar per concentrar les enquestes en quatre ciutats, però amb testimonis de les respectives àrees d'influència: Nàpols, que a mitjan segle XV era la capital de facto de la Corona d'Aragó, amb testimonis de les terres hispàniques de la Corona i, per tant, amb testimonis de llengua catalana i aragonesa; Tolosa, principal ciutat de l'Occitània sud-occidental, on predicà en Setmana Santa i Pasqua de 1416, amb testimonis de llengua occitana, alguns dels quals coneixedors del francés; Gwened, ciutat situada entre la zona francòfona i la bretonòfona del ducat de Bretanya, darrera residència de fra Vicent, amb testimonis d'una o altra llengua i bilingües; i Avinyó, important ciutat de l'Occitània oriental, seu pontifícia durant gran part del segle XIV i durant el Cisma d'Occident i lloc de residència i de predicació de fra Vicent, estretament connectada amb el nord d'Itàlia i la Suïssa romànica i, per tant, amb testimonis previsiblement de llengua occitana, arpitana, francesa, llombarda i italiana, que no coneixem, perquè no ens n'han arribat les actes corresponents.

No sabem si les actes d'Avinyó, perdudes al segle XVI, contenien respostes sobre l'opció de fra Vicent pel papa Luna incòmodes per a Roma. Les còpies de les actes del procés que es feren a

SCRIPTA, Revista internacional de literatura i cultura medieval i moderna, núm. 16 / desembre 2020 / pp. 71-130 ISSN: 2340-4841 · doi:10.7203/SCRIPTA.16.19213 
València al segle XVI procedeixen del convent dominicà de Palerm, i ja no contenen les enquestes d'Avinyó. No es van fer enquestes a les terres hispàniques de la Corona d'Aragó i a Castella. És una situació estranya si tenim en compte que, a banda del duc de Bretanya i, òbviament, dels dominicans, els més interessats en la declaració de la santedat de fra Vicent eren el rei d'Aragó, Alfons el Magnànim, i el de Castella, Joan II, agraïts com estaven al nostre predicador pel seu paper fonamental en el Compromís de Casp a favor dels Trastàmara. Potser eren enquestes que, sobretot en el cas de Castella, no convenien si qüestionaven el suposat miracle de mestre Vicent d'haver aconseguit ser entés per qualsevol parlant de llengües diferents de la seua llengua materna sense que el nostre predicador deixés d'usar la seua. D’aquest miracle, se n'ha dit do de llengües. Un do de llengües que es volia assimilar al dels apòstols després de la Pentecosta, però que casava malament amb la concepció del do de llengües que llegim als Fets dels Apòstols (2.4), que comportà que els deixebles de Jesús adquirissen la facultat de parlar diverses llengües: «Tots van quedar plens de l'Esperit Sant i començaren a parlar en diverses llengües, tal com l'Esperit els concedia d'expressar-se». ${ }^{10}$

Entre les preguntes que es feien als testimonis enquestats en el procés de canonització de fra Vicent, ens interessa, per als nostres objectius concrets, la que es referia al do de llengües del nostre predicador. En el formulari de l'enquesta de Nàpols, que és l'únic que ens ha arribat sencer, correspon concretament a la pregunta dissetena, en la qual es demanava als testimonis de confirmar si fra Vicent «també, per do de Déu, va resplendir amb tanta gràcia en el parlar que, trobant-se presents en la seua predicació milers de cristians de diferents idiomes, tots el sentien proclamar les grandeses de Déu en la seua pròpia llengua» (Esponera 2018: 574). La pregunta, almenys en el qüestionari de Nàpols, només fa referència a la «gràcia en el parlar» $i$ al fet de ser comprés per tothom. És exactament la mateixa formulació que va utilitzar Melcior Miralles (2011: 159), l'autor de la Crònica i dietari del capellà d'Alfons el Magnànim: «los seus sermons heren de tanta gràcia que totes generacions de gents l'entenien». No era una qüestió de llengua, sinó de comunicació. Per això, en algun escrit meu (Ferrando 2012) he preferit parlar del do de gents de Vicent Ferrer. No sabem si la pregunta es formulava de la mateixa manera en les enquestes de Tolosa i de Gwened. Certament, en les actes de Tolosa se'ns dona una breu llista de les preguntes principals, però entre aquestes no figura la que ens interessa (Esponera 2018: 410) i, tanmateix, aquesta qüestió fou una de les més explicitades en les declaracions dels testimonis.

10 L'hagiografia vicentina ha elaborat diverses explicacions per a intentar superar la contradicció entre el relat dels Fets dels apòstols i el do que hauria posseï mestre Vicent Ferrer de ser entés per tothom a pesar d'usar exclusivament la llengua materna (Ferrando 2019: 185-188). Francesc Almela i Vives (1927), Jesús Ernest Martínez Ferrando (1952), Joan Fuster $(1955)$ i Sanchis Guarner $(1973 ; 1974)$ han aportat explicacions racionals alternatives a la visió hagiogràfica del do de llengües de fra Vicent Ferrer (Ferrando 2019: 229-230).

SCRIPTA, Revista internacional de literatura i cultura medieval i moderna, núm. 16 / desembre 2020 / pp. 71-130 ISSN: 2340-4841 · doi:10.7203/SCRIPTA.16.19213 


\section{Sermons i enquestes a Nàpols}

No s'han conservat a Nàpols sermonaris ferrerians anteriors a la canonització de fra Vicent. No és estrany, perquè el predicador valencià s'havia posicionat a favor dels Trastàmara aragonesos, rivals dels Anjou napolitans i, doncs, no gaudia, del favor reial. La causa de la canonització de mestre Vicent no pogué avançar fins que la pau de Terracina (1443) consagrà el reconeixement papal d'Alfons el Magnànim com a rei de Nàpols. Després de l'ocupació de la ciutat de Nàpols (1442), els Trastàmara, ara també monarques napolitans, s'encarregaren de difondre-hi la devoció i el llegat de sant Vicent i volgueren ser soterrats en el convent de Sant Domènec, de la ciutat de Nàpols. Qui s'encarregà de redactar la primera biografia oficial de mestre Vicent Ferrer ja sant, en llengua llatina i a la vista de totes les actes del procés de canonització, fou el dominicà i filohumanista sicilià Pietro Ranzano, cortesà del Magnànim, que s'hi deixà endur per les declaracions d'alguns testimonis del procés, que atribuïen a mestre Vicent el do de parlar en la seua «lingua materna valentina» i ser comprés per tothom.

La tria dels tres membres de la Comissió eclesiàstica encarregada de la enquesta del procés a Nàpols (1454), el català Arnau Roger de Pallars, bisbe d’Urgell, el napolità Rinaldo Piscicello, arquebisbe de Nàpols, i el dominic aragonés Juan García, bisbe de Mallorca, responia a la voluntat de representar el conjunt de la Corona d'Aragó. Els testimonis escollits foren catalans, valencians, aragonesos, mallorquins i estrangers que havien residit en alguna d'aquestes terres en temps de mestre Vicent i que havien assistit a algun dels seus sermons o n'havien sentit a parlar. En les actes napolitanes es fa constar que fra Vicent Ferrer era conegut vulgarment com «fra Vicent de València» («de Valentia vulgariter nuncupato») (Esponera 2018: 572), se’l fa natural de València, ciutat del «regne de València», s'esmenta i es distingeix sempre entre Aragó, Catalunya, València i Mallorca, s'addueix el sintagma «ciutat i regne de València»-denominació habitual en la documentació pública de la ciutat de València- i, en cas de designar la llengua del nostre predicador, se li dona el nom de «llengua catalana», tal com es feia sempre des de la Cancelleria reial en les missives adreçades simultàniament a Catalunya, València i Mallorca (Ferrando \& Nicolàs 2011: 167). S’hi nota, doncs, l'orientació ideològica de la cort reial de la Corona d'Aragó. De fet, una gran part dels testimonis són cortesans o persones estretament relacionades amb la cort d'Alfons el Magnànim.

La majoria dels vint-i-quatre testimonis del procés de Nàpols que responen a la pregunta dissetena, exactament quinze, es limiten a manifestar que tothom entenia fra Vicent i només alguns, que declaren haver-lo sentit predicar en terres catalanòfones, remarquen que ho feia en la seua «llengua materna», excepcionalment denominada «llengua catalana». D'aquests quinze testimonis, n'hi ha un de llengua castellana, dos de llengua occitana, dos de llengua aragonesa i deu de llengua catalana (sis catalans i quatre valencians). Entre els que no es pronuncien sobre la pregunta dissetena, o no s'hi fa constar (potser perquè no convenia), hi ha un notari genovés, Antonio Curulus, que afirmà haver vist fra Vicent i haver-lo sentit predicar a la ciutat de Gènova.

SCRIPTA, Revista internacional de literatura i cultura medieval i moderna, núm. 16 / desembre 2020 / pp. 71-130 ISSN: 2340-4841 · doi:10.7203/SCRIPTA.16.19213 
Tampoc no consta la resposta de l'aragonés Bartolomé Peirilta (Peiralta?), que havia sentit fra Vicent predicar a Tortosa.

El rei Alfons el Magnànim, de llengua castellana, que havia sentit fra Vicent predicar a Saragossa, quan encara era infant d'Aragó, declarà que

in sermonibus prefati fratris Vincentii intervenerunt magna hominum turba diversarum linguarum, et publice dicebatur quod omnes intelligebant, et omnes contentabantur, et omnes admirabantur. ${ }^{11}$

Els dos testimonis occitans són Sanç de la Maurella, cavaller, originari del ducat de Guiena, i Pere, abat del monestir cistercenc de Fontfreda (diòcesi de Narbona).

Sanç de la Maurella declarà que, el 1416, va sentir sermons de fra Vicent a Aragó i Catalunya. Però en la qüestió de la llengua de la predicació remet a l'opinió i a la fama general que hi havia tant a Catalunya i Aragó com a França. Concretament, ho fa en els termes següents:

\begin{abstract}
Interrogatuts super XVII ${ }^{\circ}$ articulo (...), dixit quod omnes qui audiebant predicationes ipsius, licet essent variarum linguarum, dicebant se esse contentos sua predicatione, et ipsum intellexisse secundum propriam linguam; et ita erat communis opinio et communis fama in partibus Catalonie, Aragonie, sic etiam testis ipse in partibus Francie dixit communis est opinio. ${ }^{12}$
\end{abstract}

L'abat Pere, que a Barcelona i poblacions dels voltants sentí sermons de mestre Vicent Ferrer, «natione catalanum, de civitate Valentina» ('de nació catalana, de la ciutat de València'), declarà que fra Vicent «era entés per tots els que procedien de diversos llocs, com si parlés en la llengua de cadascú d'ells», però que això ho sabia perquè ho havia sentit per boca d'«homes molts notables de la ciutat de Mâcon l'any 1442», mentre es trobava en el capítol general de l'orde del Cistell, celebrat en aquesta població del ducat de Borgonya (Esponera 2018: 584).

Els dos testimonis aragonesos que es pronuncien sobre la llengua de fra Vicent són Juan García, bisbe de Mallorca (1446-1459) i confessor del Magnànim, i «Ferdinandus, episcopus Tholosensis» (sic), que havia estat capellà reial. El 1454, els dos bisbes residien a Nàpols.

11 Traducció: «en les predicacions de l'esmentat fra Vicent hi havia una gran multitud de persones de diverses llengües, $i$ tots deien obertament que l'entenien; i tots n'estaven contents i admirats» (Esponera 2018: 601). Aquesta referència al llibre d'Esponera i totes les que done d'ara endavant remeten a la seua traducció castellana (2018), que indica la foliació corresponent a l'edició llatina del procés de canonització (Ms. 690, de la Biblioteca Històrica de la Universitat de València), reproduïda en un CD-Rom.

12 Traducció: «Interrogat sobre l'article disseté [...], digué que tots els qui sentien les seues predicacions, encara que fossen de llengües diferents, deien que estaven contents de la seua predicació i d'haver-lo entés segons la llengua de cada u; i això era opinió general i fama general en terres de Catalunya i d'Aragó, i també el mateix testimoni digué que era opinió general en terres de França» (Esponera 2018: 582). 
La declaració de Juan García -un dels tres membres de la Comissió eclesiàstica napolitana del procés de canonització- és un dels testimoniatges més clarificadors sobre el suposat do de llengües del nostre predicador, no sols pel rang eclesiàstic i cortesà de què gaudia llavors, sinó perquè havia estat membre del seguici de fra Vicent i perquè prové d'un aragonés que manifestà haver-lo sentit predicar a Saragossa, Osca, Daroca, Alcanyís i Calataiud. Juan García atribuí a la fama pública que fra Vicent fos entés per parlants de les més diverses llengües i eludí pronunciar-se sobre la llengua que utilitzava a Aragó:

Interrogatus super $\mathrm{XVII}^{\circ}$, dixit vera esse ut communiter reputabatur et percipiebatur et intelligebatur ab omnibus diversarum linguarum. Interrogatus de causa scientie, dixit quod ita audivit, publica fama referente. ${ }^{13}$

«Ferdinandus, episcopus Tholosensis» fou, en realitat, Fernando Ximén de Urrea, natural de Calataiud, bisbe de la diòcesi siciliana de Telese (1453-1458), i no de Tolosa. ${ }^{14}$ L'acta del procés de canonització fa constar que el bisbe Fernando era un deixeble de fra Vicent Ferrer, que durant molts anys el seguí «en les seues predicacions i escoltà les seues ensenyances a Aragó, Catalunya, València, Mallorca, regne de Castella i després en el regne de França fins al ducat de Bretanya» (Esponera 2018: 588). En la seua deposició, explicà que el sentí predicar en poblacions tan diverses com Daroca, Alcanyís, Segòvia, Nantes, Tolosa, Dijon, Vilallonga (Catalunya) i Sant Martí de Conflent. Quant a l'article disseté, declarà que «unusquisque audiebat eum in sua lingua predicantem» ('cadascú el sentia predicar en la seua pròpia llengua') i que ho comprovà per primera vegada a Tolosa i per segona vegada a Dijon, a la Borgonya (Esponera 2018: 590). ${ }^{15}$

13 Traducció: «Interrogat sobre l’article disseté, va dir que era cert, segons opinió generalitzada, i que el sentien i l'entenien tots els de diverses llengües. Preguntat sobre com ho sap, digué que així ho va sentir dir i que ho confirmava la fama pública» (Esponera 2018: 606).

14 M’ha posat en la pista de la identificació Mateu Rodrigo. Cfr. Giovanni Rossi, Catalogo de’ vescovi di Telese, Nàpols, Stamperia de la Società Tipografica, 1827, pp. 101-103 i 252, que llegeix «Gemel de Gurrea». Fernando Ximén o Ximénez de Urrea pertanyia a un noble família aragonesa, que posseïa a València la Tinença d'Alcalatén. Rossi destaca com un mèrit el fet que el prelat aragonés, un «nobile spagnolo», residís a la seu epsicopal entre el 1455 i el 1458, en què morí. El nom llatí de Telese era Telesia (Telesensis), forma que facilitava la confusió amb Tolosa (Tolosensis), ja constatada a Diago (1600).

15 L'experiència viscuda a Tolosa per Fernando Ximén de Urrea succeí durant el sermó del Divendres Sant de 1416. És una anècdota reportada per altres testimonis del procés de canonització, segons veurem en ocupar-nos de la predicació tolosana. En canvi, desconeixem l'experiència de Dijon, que devia ser per una anècdota semblant. Així doncs, per al seu fidel seguidor i futur bisbe Ximén de Urrea, l'experiència de la comprensió d’unes paraules en català només l'hauria constatada en dues ocasions. Una i altra anècdota formen part del repertori d'estratègies comunicatives dels predicadors de l'època, com ho eren també les al lusions directes a l'aspecte físic o al comportament de persones concretes assistents als sermons i les insinuacions sobre els pecats que haurien comés. Els sermons de mestre Vicent Ferrer il lustren a bastament aquestes estratègies comunicatives.

SCRIPTA, Revista internacional de literatura i cultura medieval i moderna, núm. 16 / desembre 2020 / pp. 71-130 ISSN: 2340-4841 · doi:10.7203/SCRIPTA.16.19213 


\section{Antoni Ferrando Francés. La poliglòssia en la predicació de Vicent Ferrer}

Els sis testimonis catalans corresponen a Jaume Quintà, protometge d'Alfons el Magnànim; $;^{16}$ Bernat Català, natural de Prats; Lluís de Queralt, ${ }^{17}$ natural de Barcelona; Joan de Soler, de la diòcesi de Barcelona, penitenciari del papa Nicolau V; un català anònim -anonimat imputable a la pèrdua del foli de les actes amb què començava la seua deposició-, probablement originari de terres lleidatanes, i Miquel Arbiol (o Albiol), doctor en lleis.

Jaume Quintà, que havia sentit fra Vicent predicar a Lleida, declarà que

ad predicationes Magistri Vincentii plures homines et mulieres diversarum linguarum seu idiomatum confluebant, et omnes eum intelligebant ac si eorum proprio idiomate loqueretur, cum tamen materna lingua semper loqueretur. ${ }^{18}$

Bernat Català, que també havia sentit fra Vicent predicar a Lleida en presència del rei Ferran I, es limità a confessar que

ipse audivit et vidit stantes in predicatione dicti Magistri Vincentii multas gentes in idiomate differentes, et omnes qui cum teste ipso loquebantur, licet essent in idiomate differentes, dicebant illum audivisse loquentem sua lingua magnalia Dei. ${ }^{19}$

Lluís de Queralt, que havia sentit fra Vicent predicar a Barcelona i Perpinyà, manifestà

hoc scire quod omnes qui erant de longinquo audiebant sicut illi qui erant vicini, et illi qui erant theutonici, francigene et aliarum linguarum audiebant ipsum loquentem lingua cathalana et ipsum intelligebant, si eorum lingua vel aliter testis ipse ignorat. ${ }^{20}$

16 Una carta, de 31 d'agost de 1453, de la reina Maria de Castella, llavors lloctinent de Catalunya, fa referència al «novell canceller e físich del senyor rey Jacme Quintà». El «protofísich» reial morí el 1457, sent canceller de l’Estudi d'Arts i Medicina de Barcelona (M Riera 2007: 49).

17 Al manuscrit llatí llegim Cataldo, que sembla una mala trannscripció de Caralt, és a dir, Queralt.

18 Traducció: «als sermons de Mestre Vicent acudien homes i dones de diverses llengües o idiomes, i tots l'entenien com si els hagués parlat en llur llengua, tot i que sempre usava la seua llengua materna» (Esponera 2018: 577).

19 Traducció: «va sentir i va veure en la predicació de mestre Vicent molta gent de diferents idiomes i que tots aquells que parlaven amb ell, encara que fossen de llengües diferents, deien que l'havien sentit en llur llengua parlar de les grandeses de Déu» (Esponera 2018: 587).

20 Traducció: «saber que tots els qui es trobaven prop com els qui es trobaven lluny el sentien, i els alemanys, francesos i d'altres llengües el sentien parlant llengua catalana i l'entenien; si era en la seua llengua o en una altra ho ignora» (Esponera 2018: 593). L'al lusió als «alemanys, francesos i d'altres llengües» deu fer referència a part dels assistents a la conferència de Perpinyà (1416). L'al lusió al debat sobre com es produïa la comprensió univeral de la llengua usada per fra Vicent reflecteix el procés de construcció ideològica del miracle del do de llengües i, doncs, el conflicte entre realitat i mitificació. 


\section{Antoni Ferrando Francés. La poliglòssia en la predicació de Vicent Ferrer}

Ara bé, havent-li demanat «qui eren els que li ho havien dit, diu que no ho recorda, però que això era opinió general entre els qui escoltaven les predicacions de fra Vicent i que era fama pública» (Esponera 2018: 593).

Joan de Soler, que de xiquet, en braços de sa mare, havia sentit fra Vicent Ferrer predicar a Caldes de Montbui, adduí el testimoniatge d'una carta de Nicolau de Clamanges (que analitzaré més avall):

Interrogatus super XVII ${ }^{\circ}$ articulo, (...), dixit quod legit quandam epistolam missam a Magistro Nicolao de Clemengiis de Jauna Parisius, qui erat vir preclarus atque famosissimus, qui in sua epistola dicit et asserit quod dicto Magistro predicante Vincentio Janue, ubi erat diversarum linguarum multitudo maxima, propter Romane Curie concurrentiam que tunc apud Januam secundum obedientiam Domini Benedicti de Luna assentabatur, omnes diversorum ydiomatum eum in continua predicatione audientes, ita intelligebant eum ac si illius cuiusque nationis lingua loqueretur. ${ }^{21}$

El testimoni català anònim que declarà haver sentit fra Vicent predicar a Balaguer (1413), Lleida (1414) i Perpinyà (1416), manifestà

[se] vidisse in sermonibus dicti fratris Vincentii multos francigenas, theotonicos, hispanos et homines alios diversorum linguarum et ydiomatum, descendentes a predicationibus dicti fratris Vincentii contentos ac si unusquisque audivisset ipsum in sua lingua; (...) et quod publice dicebatur ipsum fratrum Vincentium habuisse gratiam Apostolorum, et omnes eum audirent sua lingua magnalia Dei loquentem. ${ }^{22}$

Finalment, Miquel Arbiol, membre del seguici de fra Vicent per terres de Catalunya i de València, va declarar

plures reperit secum hominibus variarum linguarum in predicationibus dicti fratris Vincentii, et unusquisque ex illis dicebat quod dictus frater Vincentius predicabat secundum linguam patrie ipsius loquentis, et alii dicebant quod non, et quod lingua eorum loquebatur, in tantum quod unusquisque dicebat ipsum fratrum Vincentium fuisse locutum in sermonibus propria lingua uniuscuiusque audientis. ${ }^{23}$

21 Traducció: «Interrogat sobre l'article disseté, (...), digué que llegí una carta, tramesa de Gènova a París, per mestre Nicolau de Clamanges, que era home preclar i famosíssim, on diu i afirma que, estant predicant mestre Vicent a Gènova, on hi havia molta gent de diverses llengües, ja que llavors hi residia la cúria romana de l'obediència de don Benet de Luna, tots els dels diferents idiomes sentien constantment la seua predicació i l'entenien com si els parlés en la llengua de la seua respectiva nació» (Esponera 2018: 598).

22 Traducció: «haver vist en els sermons de fra Vicent que molts francesos, alemanys, espanyols i altra gent de llengües i idiomes diferents se'n tornaven contents com si cadascú l'hagués sentit en la seua pròpia llengua (...); i que solia comentar-se que fra Vicent mateix tenia la gràcia dels apòstols i que tots el sentien en llur llengua parlar de les magnificències de Déu» (Esponera 2018: 612).

23 Traducció: «haver vist en les predicacions de fra Vicent molts homes de diverses llengües, i uns deien que fra Vicent havia predicat en la llengua pròpia de la seua regió i altres que no, que havia parlat en llur llengua, de manera

SCRIPTA, Revista internacional de literatura i cultura medieval i moderna, núm. 16 / desembre 2020 / pp. 71-130 
Els quatre testimonis valencians corresponen a Innocenci de Cubells, de la casa del rei, natural de la ciutat de València; Pere Juli, mercader de València, llavors establit a Nàpols; Joan Alvar, de València, prior del monestir de la Vall de Jesús, de canonges regulars de sant Agustí, situat a Puçol (Horta de València), i València, rei d'armes («rex armorum nuncupatus de Valentia»), oriünd segurament de la ciutat de València, ja que en la seua deposició testifical declara que coneixia la mare i els germans de fra Vicent Ferrer i que havia sentit fra Vicent predicar en el convent de Predicadors de València (Esponera 2018: 615).

Innocenci de Cubells declarà haver sentit fra Vicent en «terres d'Espanya» i que va veure «molts francesos, espanyols, sarraïns i jueus, i d'altres llengües, que deien: 'Verdaderament és un apòstol; cadascú entén la seua llengua quan parla de les grandeses de Déu’» (Esponera 2018: 580). Pere Juli, que havia sentit fra Vicent predicar a Barcelona i València, declarà que, entre la gent de diverses llengües, «la seua predicació tenia tanta força i brillava amb tanta gràcia en els seus llavis que era entés per tots perfectament» (Esponera 2018: 600). Finalment, València, rei d'armes, ${ }^{24}$ reconeix que

non obstante quod in predicationibus eius erant diverse nationes diversarum linguarum, tam christiani, pagani et judei, omnes aperte intelligebant predicationes ipsius ac si in lingua uniuscuiusque ipsorum predicasset, cum ipse frater Vincentius predicabat post latinum in lingua cathalana. ${ }^{25}$

L’objectiu explícit de l'article disseté de l'enquesta era confirmar que era fama pública que mestre Vicent era entés per tots els qui l'escoltaven i que cadascú el sentia en la seua pròpia llengua. Els dos bisbes aragonesos, que seguiren de prop la tasca missionera de fra Vicent per països de llengües diferents, es limitaren a confirmar la literalitat de la pregunta. No fan cap esment de l'ús de l’aragonés. La resta de testimonis, incloent-hi el rei Magnànim i els dos occitans, se centren en

que cadascú deia que fra Vicent en els sermons havia parlat en la llengua pròpia de cadascú» (Esponera 2018: 621). Aquesta nova al lusió al debat sobre la llengua usada per fra Vicent reflecteix una vegada més el procés de construcció ideològica del miracle del do de llengües.

24 València és el nom d'un famós rei d'armes, que intervingué en el conflicte cavalleresc entre Bernat de Vilarig i Gómez de Figueroa (1447-1448) i que, segons la seua declaració en el procés de canonització de fra Vicent, va constatar que mestre Vicent Ferrer havia aconseguit posar fi a les multiseculars baralles entre els Maça de Liçana i els Centelles. Es deia Antoni Bonet i, abans de ser nomenat rei d'armes (1444), havia estat herald (1439) en la cort napolitana de Magnànim. En el moment de l'enquesta sobre la santedat de fra Vicent Ferrer, el nostre rei d'armes es trobava a Nàpols. En la seua deposició aporta nombroses informacions sobre la percepció que es tenia a València del seu compatriota. L'ús de la denominació «llengua catalana» en un valencià com ell i en aquella època s'explica pel context cortesà i napolità en què es produí l'enquesta. Cfr. A. Ferrando (1980).

25 Traducció: «malgrat la presència en les seues predicacions de gent de diferents nacions i llengües, tant cristians com pagans i jueus, tots entenien clarament les seues predicacions tal com si els prediqués en la llengua de cadascú, tot i que fra Vicent predicava, després del llatí, en llengua catalana» (Esponera 2018: 615). El rei d’armes València distingeix clarament entre mite i realitat. Ben mirat, els testimonis napolitans són els menys influïts per la pressió ideològica del clericalisme medievalitzant que veiem a Tolosa i a Gwened. 
la comprensió universal de les predicacions de fra Vicent i només alguns d'ells reconeixen que s'adreçava als laics en la seua llengua materna, excepcionalment denominada català. Els enquestats són majoritàriament eclesiàstics, nobles, juristes i mercaders, en bona part vinculats a la cort de Magnànim. Les seues respostes, en general ponderades, s'ajusten a les orientacions ideològiques de la cort.

\section{Sermons a la Gàl lia oriental i enquestes a Avinyó}

Encara que s'han perdut les actes d'Avinyó, es conserven tres sermonaris coetanis de sant Vicent i diversos documents que ens il lustren sobre la predicació ferreriana, entre 1399 i 1408, per l'Occitània oriental, el Lionés, el Delfinat, la Savoia, l'oest romànic de Suïssa i el nord d'Itàlia (Gènova, Monferrat, Llombardia), probables llocs de provinença dels hipotètics testimonis avinyonesos (Esponera 2018: 13). Els tres sermonaris al ludits són el Ms. 62 del Couvent des Cordeliers, de Friburg (Suïssa), el Ms. G 756 de la Bibliothèque Cantonale Universitaire, de Lausanne (Suïssa) i el Ms. 477 del Convent dominicà de Perúgia (Itàlia). Encara hi ha el Ms. nouv. acqu. lat. 72, de la Bibliothèque Nationale de França (París), que conserva l'esquema d'un sermó, anònim, predicat l'any 1404 a la catedral de Belley, població situada entre Ginebra i Lió, que ha estat atribuït al nostre predicador. Una bona mostra de la intensa activitat missional de fra Vicent a les dues bandes dels Alps és la carta que aquest adreçà, el 17 de desembre de 1403, des de Ginebra, a Jean de Puynoix, Mestre general dels Predicadors, donant-li'n compte. ${ }^{26}$

El Ms. 62 del Couvent des Cordeliers, de 1406, reprodueix setze sermons predicats la quaresma de 1404 a Friburg i a altres localitats de l'actual Suïssa francòfona, llavors part del ducat de Savoia, de llengua arpitana, confinant amb terres de llengua alemanya (Perarnau 1999a). Els sermons, editats per Gimeno i per Mandingorra (2009), van ser compilats pel franciscà Friedrich von Amberg (ca. 1384-1432). El frare suís, que devia ser de llengua alemanya, tal com suggereix l'ús d'algunes convencions gràfiques d'aquesta llengua en el seu llatí, declarà que els havia recollits «de ore suo [de fra Vicent], meliori modo quo potuit». La frase pot al ludir a la dificultat de comprensió de la llengua emprada davant els auditoris laics per fra Vicent, que, com després veurem, potser intentà d'aproximar-se a l'arpità i al francés. Tots els sermons reproduïts en el manuscrit són en llatí, no porten la divisio thematis i a penes conserven cap mot o expressió en vulgar, si no és algun francesisme llatinitzat, com ribaldus. En tot cas, la llengua emprada per fra Vicent no devia diferir gaire de la que tot seguidament observarem en el sermó que poc després predicà a Belley, ciutat de llengua arpitana.

26 Els sermons atribuïts a fra Vicent de què parla Daileader (2019: 297-298, nota 18) poden estar relacionats amb la predicació ferreraria per terres del nord d'Itàlia i de la Gàl lia oriental. Entre les raons que reforcen la hipòtesi que el sermó anònim predicat a Belley és de mestre Vicent hi ha la declaració feta pel cartoixà francoprovençal, fra Joan Placentis, en el procés de canonització de mestre Vicent, segons la qual el dominicà valencià va sojornar tres dies en el santuari cartoixà de Nostra Dona de Pierre Châtel, de la diòcesi de Belley, a la Savoia, on ell el va sentir. Segons la mateixa declaració, fra Joan Placentis acompanyà mestre Vicent en les seues predicacions per la Corona d'Aragó i coincidí amb el dominicà valencià quan aquest era a la Bretanya (Esponera 2018: 364-366). 
En efecte, encara que el pla del sermó predicat a Belley sobre el tema Humiliamini (1Petr, V, 6) és en llatí, el resum que ens n'ha pervingut conté nombrosos fragments en vulgar. El seu editor, Clovis Brunel (1924), l'atribuí a fra Vicent perquè considerà que tenia molts catalanismes. Francesc Gimeno (1992: 91) també li l'atribuí, però per raons paleogràfiques, en considerar-lo autògraf. En canvi, a Perarnau (1999f: 58) no el van convéncer cap dels dos arguments, pel fet que l'esquema del sermó no s'ajusta a l'estructura característica que presenta el mateix tema en els sermons vicentins. En tot cas, sabem que, el setembre de 1404, mestre Vicent arribava a Lió, des de Ginebra, i que en el camí es troba Belley, de llengua arpitana. És inversemblant un sermó amb catalanismes predicat llavors a Belley si no era de mestre Vicent. Ara bé, com ja vaig assenyalar (Ferrando 1997: 8081), la majoria dels mots en vulgar no són catalans, sinó occitans o arpitans, com ara yeu, escuresit, Pal, gen, nosautres, plasentr, gasardó, abondós, aut, gardar, vesem, senses, anma, glesya, desya, paubretat, repaus, malaut, i això podria ser un reflex de la llengua que hauria fet servir fra Vicent, adaptada a grans trets a l'audiència arpitana. La presència d'alguns mots en català, com trobe, Déu, aquest, sembla confirmar l'autoria d'un catalanoparlant. Possiblement, els sermons predicats en terres de llengua arpitana foren els únics en què mestre Vicent hagué de recórrer a un cert hibridisme lingüístic, de base probablement occitana, ja que la seua competència en arpità, per al qual degué comptar amb l'assessoranent de fra Joan Placentis, devia ser relativa.

El ms. G 756 de la Bibliothèque Cantonale Universitaire, de Lausanne, recull cinc sermons de mestre Vicent, predicats a Montpeller el 1408, que ara podem llegir en l'edició de Franco Morenzoni (2004). Els copià, als anys vint del segle XV, un prevere de la diòcesi de Ginebra, Claude Pirusset, que degué conéixer fra Vicent quan aquest hi predicà el 1403 o el 1408 i on el dominicà valencià va deixar un record memorable. Morenzoni (2004: 230) remarca que les reportacions de Montpeller, que reiteren alguns dels temes predicats a Friburg, «ont préservé le ton vivant et attrayant avec lequel le célèbre prédicateur s'adressait à son public. Les reportations, beaucoup plus longues que celles notées en 1404, comportent de nombreuses expressions en langue vernaculaire, langue dont on perçoit la présence également derrière la plupart des passages rédigés en latin». Més encara, «en faisant regulièrement dialoguer le Christ, la Vierge, les saints, les damnés ou les élus avec de mots simples, ceux de la vie de tous les jours, Vincent Ferrier confère à ses sermons un ton à la fois réaliste et familier qui rapelle bien entendu celui du théâtre religieux». Encara afegiria jo que fra Vicent degué reeixir a atraure l'atenció de l'audiència quan contava amb gran vivesa situacions concretes que havia vist o viscut, com ara les que observà en les seues recents predicacions per la Llombardia i pel Monferrat (Morenzoni 2004: 265-266). ${ }^{27}$ Una mena de registre col loquial com aquest exigia l'ús de l'occità. Ara bé, el copista ginebrí només preservà en vulgar algunes expressions pronunciades per mestre Vicent en francés i occità. Així, en el sermó predicat a Montpeller el 4 de desembre de 1408, fra Vicent va condemnar, citant-les en vulgar, algunes expressions blasfemes. Heus-les ací en context:

27 Morenzoni transcriu Monserrat. El topònim no té res a veure amb Montis Serrati (Montserrat), com suggereix Perarnau (1999c: 360).

SCRIPTA, Revista internacional de literatura i cultura medieval i moderna, núm. 16 / desembre 2020 / pp. 71-130 ISSN: 2340-4841 · doi:10.7203/SCRIPTA.16.19213 


\begin{abstract}
Nam unus dicit: 'Je regnoye'. Et alter dicit: 'Per le ventre et per lo fege'. Et alter: 'Per le sanc'. Alter: 'Magra n'ayet aquel Dieus' (...). Et etiam vides quod unus miser puer qui nondum habebit X annos incontinenti dicet: 'Je regnoye Dieu o la Vierge Marie'. Deberet istud tollerari per istos malos dominos temporales? Nonne tu vides quod si unus homo huius mundi diceret: 'Je regnoye le roy', vel diceret: 'En despit du roy', istud fiet? ${ }^{28}$
\end{abstract}

És evident que el copista intentà reproduir unes paraules de mestre Vicent en vulgar. La major part de les paraules romàniques d'aquest fragment són exclusivament franceses (je regnoye, ayet, Dieu, Vierge, roy). D'altres poden ser tan franceses com occitanes i catalanes (ventre, fege, sanc, despit), però en un context de contacte franco-occità caldria excloure interpretar-les com a catalanes. L'exclamació «Magra n'ayet aquel Dieus» sembla deturpada. Pot ser occitana o arpitana. ${ }^{29}$ Gràcies a la preservació dels elements més realistes i alhora anecdòtics dels sermons predicats a Montpeller, el copista deixa entendre que fra Vicent utilitzà l'occità amb alguna expressió en francés, llengua que llavors només hi coneixien les elits. Però és més probable que el prevere ginebrí hagués utilitzat materials de la predicació de fra Vicent en terres ginebrines per tal d'arredonir la versió que ens ha arribat gràcies al Petit Thalamus, de Montpeller.

L'únic sermonari contemporani de fra Vicent que es conserva a Itàlia és el ja esmentat Ms. 477 del Convento dei Dominicani, de Perúgia, en forma d'esquemes, començat a copiar, segons Perarnau (1999c: 162), cap a 1414. El manuscrit conté els esquemes de quatre-cents setanta-set sermons, encapçalats per l'explicitació de la celebració litúrgica i el thema corresponent. La finalitat del recull era disposar d'un inventari molt exhaustiu de sermons predicats per fra Vicent, amb resum dels punts bàsics i ordenat d'acord amb el calendari litúrgic dominicà. ${ }^{30}$ En el preàmbul del manuscrit se'ns diu que fra Vicent els començà a replegar a partir de 1407, quan ell era a Itàlia. A la Biblioteca Apostolica Vaticana es guarden dos sermonaris ferrerians, el Vat. lat. 4375 i el Vat. lat. 7730, datables unes quantes dècades després. Segons Perarnau, tots tres deriven d'una font comuna.

Efectivament, el manuscrit de Perúgia presenta indicis que arreplega molts dels sermons predicats per mestre Vicent Ferrer al nord d'Itàlia, sobretot de l'any litúrgic que comença el diumenge XXII «post Trinitatem» de 1407 fins al mateix diumenge de l'any següent (núms. 1 a 350). De fet, hi ha una seqüencia litúrgica prou consistent fins al sermó 350, que hauria estat predicat el 22 d'octubre de 1408. Aquesta seqüència es podria allargar tres sermons més, fins al sermó 353: el de sants Simó

28 Traducció: «Un diu: 'Jo renegue'. I altre diu: 'Pel ventre i pel fetge'. I altre: 'Per la sang'. I altre: 'Pel ventre i pel fetge'. I altre: 'Maleït siga Déu' (...). I també veus que un xiquet miserable que no tindrà encara deu anys dirà de sobte: 'Renegue de Déu, o de la Verge Maria'. ¿Açò hauria de ser consentit per aquests mals senyors temporals? ¿'Tu trobes que si un sol home d'aquest món digués: 'Renegue del rei', o bé: 'En despit del rei', passaria el mateix?».

29 És una blasfèmia contra Déu. L’expressió té el seu paral lel en francés. Cfr. el Dictionnaire du Moyen Français (13301500) (s. v. maugréer). Dec la informació a Josep Martines Peres.

30 La presència d'aquell manuscrit a Perúgia es deu a un regal fet per «Leonardus de Mansuetis, de Perusio, generalis magister Ordinis Predicatorum» al convent dominicà de la seua ciutat d'origen, el 1479 (Perarnau 1999c: 160).

SCRIPTA, Revista internacional de literatura i cultura medieval i moderna, núm. 16 / desembre 2020 / pp. 71-130 ISSN: 2340-4841 · doi:10.7203/SCRIPTA.16.19213 
i Judes (28 d'octubre), el de Tots Sants i el del dia de Difunts (Perarnau 1999e: 460). Com que sabem, si són correctes les dades de Riera (2013: 419), que fra Vicent, el 26 de setembre de 1408, era a Avigliana (Piemont), el 23 d'octubre a Ais de Provença i el 29 de novembre a Montpeller, encara podríem precisar hipotèticament que el manuscrit de Perúgia hauria recollit la predicació italiana de fra Vicent fins al sermó 330 aproximadament i que del 330 al 353 n’hauria recollit l'última predicació provençal. Ara bé, els resums dels sermons d'aquesta vintena llarga de sermons no deixen entreveure el canvi d'escenari lingüístic. En l'anunci de la divisio thematis del sermó 340, l'adjectiu «maravellosa» (rimant amb «scandalosa» i «periculosa») és l'única concessió al vulgar.

Pel que fa als sermons anteriors al 330 aproximadament, no hi ha cap altra indicació topogràfica italiana ni hi ha cap sermó que porte la divisio thematis en italià. Tampoc en els resums dels sermons es perceben calcs lèxics clars de l'italià, que en tot cas caldria estudiar bé. Així i tot, són ben útils les poques notícies que duu el manuscrit sobre la predicació italiana de fra Vicent. En concret, els sermons núms. 158 i 159 s'ubiquen a Savona, on sabem que fra Vicent predicà el primer diumenge després de Pasqua de 1408 (Morenzoni 2004: 225). En quatre sermons, els núms. 97, 157, 195 i 222, es fa referència als enfrontaments entre les ciutats güelfes i les gibel lines d’Itàlia. El núm. 115 esmenta l'«argumentum Valdesium», reflex de les confrontacions doctrinals amb els valdesos al nord d'Itàlia. El núm. 256 al ludeix als «florenos de Florentia». Els adverbis en -ment («liberalment», «plenament», etc. ) de la divisio thematis del núm. 243 o la interjecció «la mort» del núm. 306 podrien reflectir formes dels parlars septentrionals d'Itàlia. En tot cas, són excepcions al criteri d'adoptar sempre el llatí, fins i tot en els anuncis de la divisio thematis. Els pocs casos en què els mots no presenten formes estrictament llatines són cultismes («clemència paternal / potència divinal / providència supernal», núm. 247) o semblen catalanitzacions adoptades pel copista a partir d'un antígraf en català, ja que el copista en ocasions afegeix al marge la divisio thematis en català.

La cronologia i la ubicació dels sermons posteriors al 353 sembla impossible, a excepció del 430, datat a Alcanyís el 27 de juliol de 1412. En tot cas, els sermons que van del 431 al 477 semblen posteriors al 27 de juliol de 1412. A partir del núm. 431, ja apareixen uns quants exemples de la divisio thematis clarament en català, com ara el núm. 441, que fa: «Com se pararen aptament, / com caminaren fermament, / com encercaren estretament, / com adoraren dignament». En el núm. 420, el copista ha afegit al marge inferior la divisio thematis següent: «Expectación de la virgen María; / Santa María de la Esperança; / Santa María de la O», que suggereix el recurs a un antígraf en castellà o aragonés. Els pocs exemples de mots romànics en català dins dels resums dels sermons es concentren a partir de l'esquema de sermó núm. 416: «Ja són dats los albarans» (416), ${ }^{31}$ «cochs de hòsties» (435), «del primsenyor» (442). El núm. 407 deixa constància de l'episodi «de heremita ad me venientem in Chavas Montisferrati sunt quinque anni elapsì: és una al lusió a la seua predicació

31 L’expressió «ja són dats los albarans» 'ja se n’ha decidit la sort', la retrobem sota la variant «ja són donats los albarans» en el sermó predicat a València el 24 de juliol de 1410 i en el sermó predicat a Tortosa el 4 de juliol de 1413 (Perarnau 1985: 266). Detectar aquesta mena de paral lelismes lèxics podria ajudar a identificar la procedència, la datació i les concomitàncies d'alguns sermons. 


\title{
Antoni Ferrando Francés. La poliglòssia en la predicació de Vicent Ferrer
}

monferratesa, que també hem vist reflectida en un dels sermons predicats a Montpeller, el 1408 (Morenzoni 2004: 266), i en un dels sermons llatins del manuscrit del Patriarca predicats a Castella el 1412, on parla que el «quartum argumentum est de marquesat de Monferat, in vila de Java» (Gimeno \& Mandingorra 2002: 521). ${ }^{32}$

Aquestes constatacions sobre el manuscrit de Perúgia podrien avalar dues conclusions provisionals. La primera és que les referències topogràfiques i culturals a Itàlia i el silenci pràcticament absolut del català en la divisio thematis fins al sermó núm. 353 suggereixen que aquesta primera secció correspon a sermons predicats per mestre Vicent al nord d'Itàlia (1407-1408), segurament en un italià progressivament amerat de septentrionalismes llombards, genovesos i arpitans, o en un italià més o menys culte, tal com va fer en el sermó que predicà a Gènova, el 1405, davant el papa Benet XIII. ${ }^{33}$ Només aproximadament la vintena final de sermons d'aquesta secció hauria recollit la darrera predicació provençal de fra Vicent. La segona conclusió és que el compilador del manuscrit, a partir del núm. 354, va recollir sermons predicats a la Península Ibèrica en català i, en uns pocs casos, en castellà o aragonés (1409?-1414?).

El silenci sobre l'ús de l'italià en aquest manuscrit de Perúgia contrasta amb l'eloqüència d'altres documents que en confirmen l'ús en la predicació vicentina pel nord d'Itàlia. Ja m’he referit a la carta, datada a Gènova el 1405, que Nicolau de Clamanges, ex-rector de la Universitat de París i secretari del papa Benet XIII, adreçà a Reginaldo Fortanini. La carta presenta mestre Vicent en aquests termes:

\begin{abstract}
Nascut a Aragó, es va traslladar a Itàlia; en arribar-hi, va començar a predicar en italià amb tanta facilitat, competència i claredat que se'l podria considerar italià de naixement. I els italians admeten que no s'entenen millor entre ells mateixos i que fins i tot l'entenien les jovenetes. Potser em direu que no és sorprenent que, parlant italià, els italians l'entenguen. D’acord, però haureu d'admetre que sorprén que, només arribar, ja dominés l'idioma. En tot cas, allò que és encara més colpidor és que parla tan bé l'italià que no solament els italians l'entenen, sinó també persones que no tenen el més mínim coneixement d'aqueixa llengua. Un alemany em va dir que havia entés totes les seues paraules com si ell hagués parlat en alemany. I jo, que entenc l'italià només a mitges, afirme que l'entenia tan bé com us entenc a vós mateix. ${ }^{34}$
\end{abstract}

32 «Chavas» o «Javas», és a dir, Civass en piemontés (Chivasso en italià), pertanyia llavors al marquesat de Monferrat.

33 No sabem quin paper pogué tenir en la predicació italiana de fra Vicent un dels col laboradors més íntims, l'italià fra Antonio d'Auria, que l'assistí personalment a Gwened en els últims moments de la seua vida i que rebé de la seua mà una Bíblia anotada, que es conserva actualment a Pisa (García Martínez 2006: 205). Ben probablement en va fer de reportador i d'assessor en matèria lingüística.

34 És traducció de la versió francesa publicada, el 1894, per Henri Dominique Fages (Ferrando 1997: 85). És de notar que fra Vicent, a pesar de ser llavors Gènova domini del rei de França i que el seu governador, el famós cavaller francés Jean le Maingre (Boucicaut), solia assistir als seus sermons, no s’adreçà a la població en francés, sinó en italià. 
Segons aquesta carta, fra Vicent predicava a Gènova en un bon italià. Tinguem en compte que, entre 1402 i 1403, ja havia estat en contacte directe amb el nord d'Itàlia, concretament amb el Piemont i la Llombardia.

Hi ha un altre testimoni de la predicació genovesa de fra Vicent, el cronista aragonés fra Martín de Alpartil (o Alpartir) (1906: 152), cubiculari de Benet XIII, que en la seua Cbronica actitatorum temporibus domini Benedicti XIII pape, redactada entre 1430 i 1441, afirma:

\begin{abstract}
El 8 de juliol arribà mestre Vicent Ferrer, que havia estat confessor del papa. Cada dia celebrava missa solemne en el cadafal instal lat en el jardí del claustre del convent de Predicadors, on s'aplegava molta gent i, acabada la missa, predicava. I com que jo, que escric aquestes notes, un dia que estava oint-lo, rodejat de molta gent, vaig dir públicament que estava admirat de com i de quina manera l'entenien, en escoltar-lo moltíssimes persones de llengües diferents, quan a penes deformava la seua llengua valenciana, llavors un alemany, persona honorable que formava part de l'auditori, respongué: «Què dius?» I jo diguí les mateixes paraules. I em contestà: «Certament, jo soc alemany i fa poc temps que soc en aquestes terres, però entenc de tal manera el mestre com si parlés la meua llengua materna». En vaig quedar estupefacte, però vaig considerar que l'Esperit Sant l'infonia la gràcia del temps de la predicació dels apòstols. ${ }^{35}$
\end{abstract}

Alpartil, que havia estudiat a Lleida, sabia que els valencians designaven la seua llengua com a valenciana, tal com es va posar de manifest solemnement al Compromís de Casp (1412) (Ferrando 2013a). Segons la seua crònica, mestre Vicent Ferrer hauria deformat la seua llengua materna per tal de fer-se entendre a l'auditori genovés. Hi tindríem, per tant, una altra prova que el nostre dominic s'esforçava a adaptar-se a la llengua majoritària dels seus oients. Ben mirat, Alpartil fa seua la constatació de Nicolau de Clamanges, incoent-hi la conversa amb un alemany, encara que en reinterpreta el contingut per tal de presentar-ho tot, no com a prova de competència lingüística excel lent de mestre Vicent, sinó com un miracle. ${ }^{36}$

Hi ha encara un manuscrit en llatí de procedència italiana amb sermons de fra Vicent Ferrer, no estudiat encara, que podria donar pistes sobre la predicació de mestre Vicent per aquelles terres. És el Ms. 5-1-16, de la Biblioteca Colombina de la catedral de Sevilla, del segle XV, en paper, que

35 És traducció del text llatí, que fa així: «VIII iulii aplicuit dominus magister Vincencius Ferrer, olim confessor pape, qui cotidie celebrabat missam altam in monasterio Predicatorum in quodam catafali constituto in pratu claustri monasterii Predicatorum, et expleta missa predicabat, ubi erat infinitus populus. Et cum ego, qui hec scribo, quadam die ipsum audirem, me multitudine circumdato, dixi publice quod mirabar cum ipsum audirent infinite gentes diversarum linguarum, cum ipse vix fi[n]geret ling[u]am Valentinam, qualiter nec quomodo ipsum intelligebant; unus de circunstantibus satis persona honesta Alamanus respondit: ‘¿Quid dicitis?’ Et ego replicavi eadem verba. Qui dixit: 'Certe ego sum Alamanus, et est modicum tempus quod ego sum in istis partibus; sed ita bene intelligo magistrum quantum linguam maternam'. De quo stupefactus fui; sed consideravi quod Spiritus Sanctus infundebat illam intelligenciam sicut tempore predicacionis apostolorum».

36 La carta de Nicolau de Clamanges devia ser prou coneguda, perquè, com hem vist, l'adduí Joan Soler, un dels testimonis de l'enquesta napolitana del procés de canonització de fra Vicent Ferrer.

SCRIPTA, Revista internacional de literatura i cultura medieval i moderna, núm. 16 / desembre 2020 / pp. 71-130 ISSN: 2340-4841 · doi:10.7203/SCRIPTA.16.19213 
fou adquirit pel bibliòfil Fernando Colón a Ferrara, el 1521. Es titula Sermones varii, ad quorum calien estat (sic) quidam tractatus Angeli de Perusio «De societatibus in negotiationibus》 (García Martínez, 2006: 54 i 71). L'afegit final, amb el tractat d'Angelo degli Ubaldi o de Perusio, jurista italià del segle XIV, comentarista del dret romà, suggereix la factura italiana d'aquest sermonari vicentí. No sabem, però, si el manuscrit forneix notícies sobre l'itinerari italià de fra Vicent. ${ }^{37}$

He suposat, seguint un suggeriment d'Esponera, que els testimonis de les enquestes d'Avinyó devien provenir d'una ampla cruilla geogràfica franco-italo-suïssa. Això significa que fra Vicent s'hi va haver d'enfrontar amb situacions lingüístiques molt diverses. Les llengües que fra Vicent degué usar en els seus sermons a la Gàl lia oriental i a la Itàlia septentrional no podien ser sinó el francés, l'occità i l'italià, que coneixia bé, amerats, segons els diversos escenaris geogràfics, d'elements de les llengües més locals (arpità, genovés, llombard), que pogué assimilar progressivament. El resultat garantia una comprensió bàsica dels sermons, i el missatge que devien transmetre els seguidors i devots del famós predicador és que, independentment de la llengua de la predicació i de l'auditori, se l'entenia, com ja constatem en Clamanges.

\section{Sermons a l'Occitània occidental i central i enquestes a Tolosa}

Quan mestre Vicent predica a Tolosa entre el 10 i el 30 d'abril de 1416, els seus oients no devien tenir problemes de comprensió, ja que el nostre predicador coneixia el llenguadocià, la varietat occitana més semblant al català. És a Tolosa que fra Vicent Ferrer va predicar el famós sermó de Divendres Sant, de sis hores de durada, i que hui coneixem sobretot a través de la traducció occitana coetània, editada per Clovis Brunel (1954).

Com a testimoniatge de la presència de fra Vicent a Tolosa i a les regions del voltant, la Bibliothèque Municipale de la ciutat conserva dos manuscrits en llatí, el Ms. 345 i el Ms. 346, que contenen sermons de tot el cicle litúrgic (Perarnau 1999b: 480). A la Biblioteca Capitular de la catedral de Sevilla es guarden dos manuscrits en llatí amb sermons de mestre Vicent Ferrer, que semblen estar relacionats amb les reportacions tolosanes de 1416. Són el Ms. 56-5-31, Sermones de dominica Trinitatis usque ad Adventum, en paper, de 1432, de 343 folis, i el Ms. 56-5-32, Sermones quadragesimales, en paper, de 123 folis, que es tanca amb un Sermo habitus ad sanctam synodum Basilensis, anno 1437, de Juan de Montenegro, que ens permet datar el manuscrit aquest any o en un dels anys immediatament

37 Hi ha molta recerca d'arxiu a fer sobre la predicació italiana de fra Vicent Ferrer. A Ferrando (2013b: 78-80) done alguna mostra dels records de la presència de fra Vicent a la Itàlia septentrional, des del poema anònim en llatí dedicat a sant Vicent («Magne pater, o Vincentii»), que es conserva en la Biblioteca Communale Ariostea, de Ferrara, fins al retaule de Bartolomeo degli Erri amb la imatge de sant Vicent predicant damunt d'un cadafal davant l'església de Santa Eufèmia, de Verona (actualment a l'Ashmolean Museum, d’Oxford). Vicent Martines (2012) ha destacat la presència primerenca de la iconografia vicentina a Itàlia, sobretot a l'antiga república de Venècia i a l'antic regne de Nàpols. Recentment, Ana Maria Compagna (2019) i Chiara Concina (2019) s'han ocupat de la fama de la predicació i de la difusió del culte a sant Vicent a Itàlia. 
posteriors (García Martínez 2006: 70-71). L'un i l'altre manuscrit porten nombrosos anuncis de la divisio thematis en llengua catalana. A falta d'una edició i d'un estudi de tots aquests sermons, que poden aportar indicis sobre la llengua de la predicació tolosana de fra Vicent, ${ }^{38}$ ens hem de cenyir a les informacions sobre la divisio thematis que ens ha fornit Perarnau (1999b) i a les dades pertinents de les declaracions dels testimonis enquestats per la Comissió eclesiàstica de Tolosa sobre la vida i miracles de mestre Vicent. Aquesta Comissió va ser presidida per Joan Arnau, canonge i arxidiaca de l'església metropolitana de Tolosa, en representació del seu arquebisbe, Bernat de Roserge (1454).

L'anunci de la divisio thematis dels dos manuscrits llatins de Tolosa apareix predominantment en llatí. Ara bé, quan aquests anuncis apareixen en vulgar, els casos enunciats en occità dupliquen els casos enunciats en català, si bé les diferències lingüístiques entre català i occità són mínimes, i hi ha molts exemples d'hibridisme català/occità, llatí/occità i llatí/català. Aquesta mena d'hibridismes no té res a veure amb l'oralitat vicentina, independentment de l'ús puntual de citacions i de recursos expressius en una altra llengua diferent de la seua que fra Vicent en pogués fer. Té a veure amb la transmissió textual de la predicació vicentina i s'explica pel procés d'elaboració dels dos manuscrits, molt semblant al d'altres manuscrits vicentins de l'època. La compilació dels manuscrits tolosans, que ha estat considerada com la base de les edicions incunables dels sermons ferrerians, deu ser el resultat del maneig d'antígrafs en occità, català, castellà i llatí. Observant, per exemple, l'esquema del sermó núm. 209 de l’inventari de Perarnau (1999b: 555-556), podem constatar que el Ms. 345 reprodueix literalment la mateixa redacció híbrida de l'anunci de la divisio thematis del Ms. 46 de la biblioteca de la catedral de Pamplona, amb sermons de fra Vicent Ferrer:

Tres dies permaxime sunt venturi et diligenter precogitandi: 1. dies mortis corporalis, quem debemus cogitare tremolosament, 2. dies judicii generalis, quem debemus pensare dolorosament, 3 . dies vite eternalis, quem debemus sperare gaudiosament.

Aquest mateix esquema, però íntegrament en català, excepte les paraules introductòries en llatí, és el que trobem en el manuscrit d'Avinyó, anterior al tolosà. Tot fa pensar que el compilador del manuscrit de Pamplona ha tingut present el manuscrit de Tolosa o la seua font. De l'anunci d'una divisio thematis com aquesta difícilment es pot deduir la llengua de la predicació de mestre Vicent. Però quan en el manuscrit tolosà tenim una majoria d'exemples de la divisio thematis en occità, podem sospitar que aquesta devia ser la llengua de la predicació de fra Vicent en terres occitanes. Ho podria avalar la presència de mots o de frases en occità en el cos dels sermonaris llatins de Tolosa, però la desconeixem, perquè no s'ha fet cap estudi en aquest sentit.

38 García Martínez (2006: 70) fa notar que aquests dos manuscrits pertanyen probablement a l'«ámbito aragonés» i que foren regalats per cardenal Juan de Cervantes, a mitjan segle XV, a la Biblioteca Capitular de Sevilla. Ara bé, atés que el cardenal Cervantes solia residir a Itàlia des del 1426, caldria estudiar si la còpia d'aquests sermons té res a veure amb la difusió de la predicació de mestre Vicent Ferrer per terres centreeuropees. Concretament, la datació d'ambdós manuscrits (1432 i ca. 1437) se situa en plena celebració del concili ecumènic de Basilea (1432-1449), en què participà el cardenal Cervantes. 
Riquer (1964a; 1964b: II, 214-215) ja va fer veure que els cinquanta-un sermons primers dels cinquanta-cinc dels Mss. 278 i 279 (numeració moderna) de l'ACV que foren publicats per Josep Sanchis Sivera (1932-1934) contenen uns resums amplis dels sermons predicats per fra Vicent al Llenguadoc entre el 27 de maig i el 28 de juliol de 1416. En resumeixen, en català, el contingut, però no reflecteixen la llengua en què foren predicats, que hagué de ser en occità, ja que, com afirma Riquer (1964a: 167), «se hace imposible admitir que [mestre Vicent] no supiera lenguadociano», després d'una dotzena llarga d'anys residint en terres occitanes. Sanchis Sivera (1932: 12-13) considera que aquests Mss. 278 i 279, junt amb els altres dos del mateix arxiu catedralici, els Mss. 276 i 277 (numeració moderna), titulats Reportationes sermonum Reverendissimi Magistri Vincentii Ferrarii, predicatoris finis mundi, deriven d'un antígraf desconegut. ${ }^{39}$ Els sermons predicats a Tolosa contenen preferències lèxiques valencianes $i$ algunes incrustacions lèxiques castellanes $i$ aragoneses (Casanova, 2008: 37-44). ${ }^{40}$ La dèbil influència occitana que s'observa en uns quants mots com croy, drut, lausengeria, veray, xant -en realitat, són occitanismes trobadorescos plenament integrats en el català literari o mots compartits per una i altra llengua- no sembla tenir res a veure amb la predicació llenguadociana d'aquests sermons.

Tot fa pensar que el compilador o els compiladors d'aquests quatre manuscrits de la Seu de València, que perseguien oferir als predicadors locals unes eines pastoralment útils, van manejar antígrafs en català i en aragonés o castellà, però van respectar bàsicament les reportacions de l'antígraf català. Concretament al Llenguadoc, fra Vicent degué adaptar i actualitzar el contingut de les reportacions de sermons ja predicats a la Corona d'Aragó i a Castella (1409-1415), ${ }^{41}$ però predicant-ne el contigut en occità. La quantitat i diversitat de les petges en aragonés o castellà ultrapassen de llarg el que podrien ser uns mers recursos oratoris de fra Vicent. L'expressivitat i els recursos col loquials de les Reportationes de l'ACV exclouen la possibilitat d'una traducció de l'occità. Més encara, les preferències lèxiques valencianes que s'observen en molts d'aquests sermons posen de manifest que degueren ser predicats majoritàriament a València.

39 La correspondència entre els volums de les Reportationes i l'edicions de Sanchis Sivera i de Gret Schib són les següents (nmeració moderna dels manuscrits): Ms. 176 (vols. IV, V i VI de Schib), Ms. 277 (perdut, amb reconstrucció parcial per Perarnau 1984), Ms. 278, f. 1-125v (vol. III de Schib), Ms. 278, f. 126r-252v (vol. IV de Schib); Ms. 279, f. 1-253v (vols. I i II de Sanchis Sivera), i Ms. 279, f. 254-281v (vol. III de Schib).

40 Heus ací uns quants exemples de les preferències lèxiques valencianes que llegim en les Reportationes de la Seu de València, usades sovint al costat de geosinònims més generals: acaminar (caminar), acurtar (acurçar), ausades (certament), corder (anyell), febra (febre), gemecar (gemegar), malair (maleir), oroneta (oreneta), rata penada (rata pinyada), tos (bescoll). Aquestes preferències són majoritàriament compartides per una bona part del català nord-occidental. Entre els mots castellans i aragonesos, destaquen alcançar, bando, colmillos, esti, ganado, medir, mentira, mentirós, mosquitos, onso, pico, sombra, vellaco i xillar.

41 No ens han arribat les reportacions presumiblement en occità que van fer, entre d'altres, Joan Salvaire, Berenguer Albert, Joan Hug i Antoni Marronis, testimonis del procés de canonització tolosà de fra Vicent, que declararen que s'afegiren al seu seguici el 1416 i que copiaren els seus sermons. Cap d'ells declarà que fra Vicent hi predicà en català o valencià. 
Des del Llenguadoc, mestre Vicent es desplaça cap a l'Alvèrnia. En octubre de 1416 és al Puig de Santa Maria. Abans de deixar les terres d'oc per a passar a les d'oil, fra Vicent sojornà a la ciutat de Clarmont i a la llavors veïna Montferrand entre el 21 de novembre i finals de desembre de 1416 (Sève 1951: 665-671). Ací va predicar els sermons de l'Advent d'aquell any. Com a record de la nomenada de fra Vicent, la capital de l'Alvèrnia, actualment Clarmont-Ferrand en occità, conserva un manuscrit en llatí, acabat de copiar cap a 1420, amb sermons predicats per fra Vicent en la quaresma de $1417 \mathrm{i}$ d'altres de posteriors. Es tracta del Ms. 45 de la seua Bibliothèque Municipale et Interuniversitaire, que pertangué al convent dominicà de la ciutat. Aquests sermons foren predicats a l'Alvèrnia, però ja no a la seua capital. Perarnau (2003: 343-550) n'edità catorze. Només per la petita part publicada sabem que en un sermó es reprodueixen uns versos en occità sobre el sol i la lluna («O saynt Orient»), que la versió llatina preserva termes occitans llatinitzats, com mezinarias 'metzineries' o presione 'presó', fidel reflex de l'oralitat vicentina, i que el traductor de les reportacions al llatí, presumiblement occità, deixà sense traduir alguns termes occitans com li espaventa 'els espantaocells', pluma 'ploma', la brasa 'l'espurna'. També sembla occità, en aquest context, l'exclamació A la mort, a la mort. Els sermons publicats no presenten petges lèxiques exclusivament catalanes i no n'hi ha cap de castellana, aragonesa o francesa. La citació per mestre Vicent del refrany que «dicitur communiter: 'Qui non fay quant poyria, quant volria non se fayria'» (Peraranau 2003: 351) confirma que els sermons de la quaresma de 1417, presumiblement adreçats al poble en general, degueren ser predicats en occità.

Les actes tolosanes del procés de canonització (1454) recullen els testimonis de quaranta-quatre enquestats, la major part dels quals residents a Tolosa. Predominaven els eclesiàstics i els homes de lleis. En la presentació sintètica del qüestionari que s'havia de sotmetre als testimonis escollits no figura la qüestió de la llengua usada per mestre Vicent en els seus sermons. Tanmateix, hi devia ser, perquè hi hagué deu testimonis que s'hi pronunciaren. Dels altres trenta-quatre testimonis, només alguns es limitaren a destacar que el sentien tant els qui estaven prop d'ell com els qui n'estaven lluny. Dels deu testimonis que manifestaren que l'entenien persones de diverses llengües com si els hagués parlat en llur llengua pròpia, n’hi ha cinc que no es pronuncien sobre la llengua usada pel nostre predicador i cinc que en parlen, bé identificant-la (quatre casos) o bé caracteritzant-la (un cas). Cal destacar que cap dels quaranta-quatre testimonis addueix el record d'una estada de fra Vicent a Tolosa com a estudiant, i també que, a diferència de les enquestes de Bretanya, no n’hi ha cap testimoni que faça menció de l'ús de francés en la seua predicació tolosana.

Els cinc testimonis que es limiten a destacar la comprensió total dels sermons de fra Vicent, independentment de la competència lingüística dels oients en la llengua del predicador i sense identificar-ne la llengua, són: Egidi Morelh, dominicà de Tolosa, d'uns 45 anys, que havia sentit fra Vicent predicar a Nîmes; Pèire Gautièr, també dominicà de Tolosa, de més de 60 anys, que havia sentit fra Vicent predicar a Tolosa, Muret i altres poblacions occitanes; Joan Marcel, franciscà de Tolosa, de més de 58 anys, que havia sentit fra Vicent Ferrer, «Valentinus natione», predicar a Vilafranca de Roergue; Joan Salvaire, batxiller en decrets i rector de la parròquia d'Auriac, de prop de 58 anys, que

SCRIPTA, Revista internacional de literatura i cultura medieval i moderna, núm. 16 / desembre 2020 / pp. 71-130 ISSN: 2340-4841 · doi:10.7203/SCRIPTA.16.19213 
havia seguit fra Vicent durant any i mig i havia fet d'estenògraf dels seus sermons; i el prevere Joan Regis, capellà major de la catedral metropolitana de Tolosa, natural de Castres, d'uns 64 anys.

En concret, Egidi Morelh invocà el testimoni d'un dels membres del seguici de fra Vicent, segons el qual el predicador valencià era comprés per tothom (Esponera 2018: 428); Pèire Gautièr també es limità a reproduir l'opinió d'altri: «Digué, a més, qui parla haver sentit a molts que els qui l'escoltaven, de qualsevol llengua que fossen, entenien tan bé la seua predicació com si els hagués parlat en la llengua de cadascú d'ells, i que el sentien tant els qui es trobaven prop com els qui es trobaven lluny» (Esponera 2018: 465); Joan Marcel s'expressà impersonalment: els oients de «diferents llengües i nacions» sentien i entenien la predicació de fra Vicent «en llur llengua pròpia» (Esponera 2018: 476); Joan Salvaire declarà que «mestre Vicent tenia tanta gràcia de Déu que l'entenien en tota mena de llengües» (Esponera 2018: 489), ${ }^{43}$ i Joan Regis «digué saber que molts oients eren de diverses llengües; no obstant això, el mateix que parla sentí dir a molts d'ells que, a pesar de ser de diferents llengües i nacions, entenien fra Vicent com si fos natural de llur llengua i pàtria» (Esponera 2018: 534). ${ }^{44}$

Dels cinc que es refereixen a la llengua emprada per mestre Vicent, n'hi ha un, Galhard de Ruppe, carmelità, mestre en Teologia, de 50 anys d'edat, que havia sentit mestre Vicent predicar a Tolosa el 1416 i que constata que «encara que la seua llengua era estranya a la nostra, de fet era entés per tots els qui, assabentats de la seua fama, acudien a sentir-lo» (Esponera 2018: 513). ${ }^{45}$ Amb la qualificació de llengua «peregrina» 'estranya', el frare carmelità potser volia posar l'accent en la pronunciació estrangera del mestre. En canvi, els altres quatre testimonis afirmen que mestre Vicent predicava en el seu «vulgari idiomate Catalonie seu Valentino» (Bernat de Roserge), en «linguam Valentinam seu Cathalonicam» (Galhard d'Ahust), en «vulgari Catalanico seu Valentino» (Joan de Saxis) o en «suo vulgari ydiomate Catalano sive Valentino» (Berenguer Albert).

Mirem ara els contextos en què apareixen aquestes quatre declaracions. Bernat de Roserge, arquebisbe de Tolosa, de 53 anys, que sentí fra Vicent, «nationis Valentini», predicar a Tolosa el 1416, es fa ressò en la seua declaració del que es deia sobre el do de llengües del nostre dominicà,

42 Text llatí: «Dixit insuper loquens se audivisse a pluribus quod audientes, cuiuscumque lingue essent, eius predicationem ita perfecte ipsum intelligebant ac si loqueretur proprium ydioma cuiuslibet».

43 Text llatí: «dictus Magister Vincentius habebat a Deo tantam gratiam quod universa genera linguarum ipsum intelligebant». En la seua declaració, Joan Salvaire afirmà que, el 1416, s’afegí a la companyia itinerant de fra Vicent amb molts altres estudiants de Tolosa i que el seguí durant any i mig, transcrivint els seus sermons (Esponera 2018: 487).

44 Text llatí: «Et se scire dixit quod plures audientium erant diversarum linguarum, tamen audivit a pluribus eorumdem quod quamquam esset diversarum nationum et linguarum ipsi eundem fratrem Vicentium intelligebant ac si esset de eorum propria patria et lingua».

45 Text llatí: «Lingua cuius licet esset a nostra peregrina, ab omnibus qui de multis partibus mundi, audita eius fama, conveniebant, percipiebatur». 


\section{Antoni Ferrando Francés. La poliglòssia en la predicació de Vicent Ferrer}

licet idem Magister Vincentius predicando loqueretur in suo vulgari idiomate Catalonie sen Valentino, tamen omnes audientes tam Tholosani quam Baschones et Gallici, necnon et aliarum nationum seu linguarum presentes ibi convenientes confitebantur ac dicebant plenarie et perfecte dictum Magistrum Vincentium predicantem intellexisse, et sua verba percepisse: quod etiam reputatum fuit per omnes ad singulare miraculum et ad speciale donum. ${ }^{46}$

Galhard d'Ahust, tolosà, doctor en lleis, jutge i conseller reial, de més de 64 anys, que afirmà haver sentit a Narbona dos sermons de mestre Vicent, natural «de la ciutat de València, del regne d'Aragó», manifestà que era una opinió generalitzada que

in ipso Magistro divina videbatur tantum operari gratia, quod licet ipse linguam Valentinam seu Cathalonicam haberet et illa utebatur, cuiuscumque vero quantumcumque a lingua illa prorsus extranei et segregati intellectus percipiebat eumdem, et efficaciter ex eius doctrina proficiebat. ${ }^{47}$

Berenguer Albert, canonge de Tolosa i batxiller en Drets, de 60 anys, que havia sentit a Tolosa molts sermons de mestre Vicent Ferrer, «de nació catalana o valenciana» («nationis Catalanus sive Valentinus»), i que havia pres nota dels seus sermons, declarà, en relació al famós sermó de Divendres Sant de sis hores de durada predicat per fra Vicent a Tolosa el 1416, que

omnes cumque nationis sive lingue utriusque sexus et tam parvuli quam adulti eum cum omni silentio et attentione prefacte auscultabant, audiebant et perfecte intelligebant, quamquam idem vir gloriosus suo vulgari ydiomate Catalano sive Valentino loqueretur. ${ }^{48}$

Finalment, el tolosà Joan de Saxis, cavaller, senyor de Pauliac, doctor en lleis, de 50 anys, que confessà haver sentit a Tolosa diversos sermons de fra Vicent Ferrer, «oriundus ut pro tunc dicebatur regni Valentie» ('oriünd segons es deia del regne de València'), declarà sobre l'assistència al famós sermó de Divendres Sant de 1416 que

cum dicta die Veneris Sancta plures foranei et alienigene diversarum nationum, patriarum et linguarum variarum ibidem convenissent ad audiendum et videndum predictum famosum

\footnotetext{
46 Traducció: «encara que el mateix mestre Vicent parlés en les seues predicacions en el seu idioma vulgar de Catalunya $\mathrm{o}$ valencià, tots els que l'escoltaven, tant si eren tolosans com si eren gascons i francesos, i fins i tot els que, procedents d'altres nacions o llengües, s'hi congregaven per tal motiu, reconeixien i deien que entenien plenament i perfectament els sermons que predicava el susdit mestre Vicent i que entenien les seues paraules, la qual cosa fou considerada per tots com a singular miracle i com a do especial» (Esponera 2018: 420).

47 Traducció: «en el susdit mestre es veia obrar de tal manera la gràcia divina que, encara que tingués la llengua valenciana o catalana com a pròpia i que parlés en ella, qualsevol dels oients, fins i tot els més estranys $\mathrm{i}$ allunyats d'aquesta llengua, l'entenia i obtenia profit eficaç de la seua doctrina» (Esponera 2018: 484).

48 Traducció: 《tots, de la nació o llengua que fossen, d'ambdós sexes, i tant pàrvuls com adults, l'escoltaven amb gran silenci i atenció, i el sentien i l'entenien perfectament, encara que el mateix varó gloriós parlava en el seu idioma vulgar català o valencià» (Esponera 2018: 492).
} 


\begin{abstract}
Magistrum Vincentium, Regni Valentie oriundus, et loqueretur in vulgari Catalanico seu Valentiano, tamen foranei et alienigene eius verba capiebant, intelligebant, et illa referebant in eorum idiomate ac si fuissent compatriote et eiusdem lingue. ${ }^{49}$
\end{abstract}

Remarquem que tots quatre testimonis declaren que van sentir fra Vicent predicar en la plaça de la catedral de Tolosa el sermó del Divendres Sant i que, predicant en català o valencià, era entés per tothom. No diuen, però, que tot el sermó era en català o valencià. Contextualitzant aquestes paraules en el conjunt de les declaracions, hem d'entendre que afirmen que fra Vicent era comprés quan parlava en català o valencià, és a dir, en l'ocasió o en les ocasions en què recorria a la llengua materna. Efectivament, en aquell llarguíssim sermó pronunciat el 21 d'abril de 1416, fra Vicent en va fer ús en dues ocasions: «ipse frater Vincentius, alta voce, interrumpendo sermonen suum, dixit verba sequentia seu similia: 'Digau en [= an] aquell dolent qui dorm sus la muralla que s'esvel le, altrament tombarà e farà son dany [ $=\mathrm{dan}]\rangle^{50}$. I, veient que l'home s'havia adormit de nou, advertí al grup on es trobava aquest home: «Aquell mezquí, si ss romp lo coll, serà dupte de la sua ànima e valria més que stigués en la sua casa». Així ho declarà el cavaller Jaume Ysalgueri, de 70 anys (Esponera 2018: 430). Observem que el declarant es limità a dir que fra Vicent s'havia adreçat en català a un grup d'oients, no a tot l'auditori, i que l'ús del català es limità a aquestes frases. Els receptors dels advertiments de fra Vicent devien ser els membres catalanòfons de la companyia de penitents i devots que portava amb ell. Deixant a part alguna exclamació, aquestes dues frases foren probablement les úniques frases que fra Vicent digué en català en veu alta. Altrament, s'hi hauria fet constar en un procés en què es volien acumular miracles en favor de la canonització de fra Vicent, entre els quals el del do de llengües.

De fet, hi hagué altres dos testimonis que reiteraren la mateixa anècdota, circumstància que sembla avalar-ne l'autenticitat i l'excepcionalitat: el notari Esteve d'Ardenta, de més de 48 anys, manifestà que son pare li havia contat que fra Vicent s'adreçà a un home que s'adormia durant el sermó amb «talia seu similia verba: 'Revelate [= Esvel lat en] aquell que dorm así dessús, car perill és que, si tomba a [= e] mor, que sia damnat'» (Esponera 2018: 511), i el prevere Joan Regis, de 64 anys, amb les paraules següents: «Digau en aquell mesquí qui dorm que s'esvel le» (Esponera 2018: 538). És improbable que els testimonis recordessen en català les paraules del predicador i que els enquestadors les escrivissen espontàniament en grafia catalana, tot i que deturpada. Degueren estat

49 Traducció: «en aquell Divendres Sant hi van coincidir molts forasters i estrangers de diverses nacions, de diferents pàtries i llengües, per tal d'escoltar i veure el famós mestre Vicent, natural del regne de València. I encara que parlava en vulgar català o valencià, els forasters i estrangers copsaven el significat de les seues paraules, les comprenien i les contaven en les seues respectives llengües com si fossen compatriotes i parlessen la llengua d'ell» (Esponera 2018: 503). En lloc de Valentiano, Fages llegeix Valentino, lliçó més adequada.

50 En el català de València del temps de fra Vicent Ferrer (i en el d'ara) s'usava la preposició ad, davant del demostratiu aquell. En el català de Barcelona s'usava (i s'usa) oralment an en lloc d'ad davant demostratiu. La coincidència dels tres testimonis a posar en suggereix que la frase els degué ser mostrada pels enquestadors. En la llengua de l'època, dany encara s'escrivia pertot arreu dan. El canvi es produí al segle XVI. Possiblement, fou Antist qui n'actualitzà la grafia. Esponera llig digan per «digau».

SCRIPTA, Revista internacional de literatura i cultura medieval i moderna, núm. 16 / desembre 2020 / pp. 71-130 ISSN: 2340-4841 · doi:10.7203/SCRIPTA.16.19213 
suggerides pels enquestadors. Un dels enquestats, Esteve d'Ardenta, tenia el 1416 poc més de 8 anys. Ben mirat, els tres testimonis que conten l'anècdota es limiten a precisar que fra Vicent va utilitzar la seua llengua en un moment determinat, sens dubte per a cridar més l'atenció, ja que un dels qui l'escoltaven s'havia adormit i podia caure i espatlar-se, i que tanmateix tothom que el va sentir el va entendre.

Altrament, els quatre testimonis que declaren que mestre Vicent va parlar (puntualment) en «català o valencià», remeten a un estat d'opinió generalitzat. Ells no el van sentir predicar en català o valencià. Per la seua banda, Galhard de Ruppe, en qualificar de «peregrina» ('estranya') la llengua de fra Vicent, es limitava a expressar la percepció d'estrangeria que inevitablement té per a un autòcton la llengua pròpia en boca d'un no nadiu.

Amb la seua declaració, tots quatre testimonis perseguien avalar un dels miracles que s'atribuïen a fra Vicent, el del do de llengües, amb el propòsit d'homologar-lo amb els apòstols. Era sens dubte una declaració induïda per l'ambient d'exaltació d'un predicador que s'havia fet famós perquè curava malalts i ressuscitava morts. Tanmateix, un d'ells, Berenguer Albert puntualitza que, entre els qui l'escoltaven, hi havia «multi viri periti et literati eius sermones scribentes tam in latino quam in vulgari sive romantio» (Esponera 2018: 491). El vulgar o romanç de Tolosa era l'occità. No és difícil advertir que, atesos els objectius del procés de canonització, alguns dels enquestats van voler convertir en miracle una anècdota real, que consistia en la mera comprensió d'unes paraules en català, molt pròximes a l'occità, que podrien haver estat compreses amb la mera gesticulació del nostre predicador.

Que l'ús de la doble denominació de la llengua sembla una declaració induïda, prou que ho deixa entendre el fet, excepcional en les actes del procés de canonització, que, en dos d'aquests quatre casos, mestre Vicent siga presentat com de «nació valenciana» (Roserge) o de «nació catalana o valenciana» (Berenguer) i que en un tercer cas (Joan de Saxis) siga adscrit al «regne de València», quan la cosa més usual a l'estranger, per aquells anys, era que els naturals de València fossen adscrits a la «nació catalana» i a la «llengua catalana» i vinculats a Aragó, com a designació dels dominis dels reis de la Corona d'Aragó (Ferrando 1980). Probablement el reflex en les actes del procés de canonització de fra Vicent Ferrer de l'ús de la doble denominació de la llengua en una ciutat estrangera com Tolosa no es podria explicar sense els comentaris que devien fer els nombrosos valencians que formaven part del seguici del predicador valencià, entre els quals hi havia alguns estudiants valencians de teologia en aquella ciutat, com Joan de Gentilprat i Rafael Cardona, que s'incorporaren al seu seguici el 1416 (Diago 1600: 238).

Comptat i debatut, el silenci del 90\% dels enquestats tolosans sobre la llengua usada per mestre Vicent en els seus sermons -a part de les llatinades de rigor- és revelador de la inexistència d'un problema de comunicació entre fra Vicent i el seu auditori. La comunicació oral, adreçada al lä̈cat, només podia ser en occità i, contràriament a les declaracions d'un bon nombre de testimonis, difícilment podria ser efectiva entre els que es trobaven lluny dels cadafals des dels quals predicava mestre Vicent. 
Si analitzem críticament el conjunt de les actes de Tolosa en el tema de la llengua de la predicació usada per mestre Vicent, podrem observar que són molt majoritàries les declaracions dels qui es limiten a reconéixer que el miracle comunicatiu del nostre predicador residia més en les gestos i el to de la veu que no en la paraula.

\section{Sermons i enquestes a la Bretanya}

La darrera etapa missionera de mestre Vicent Ferrer, des d'abril de 1417 al 5 d'abril de 1419, en què mor a Gwened, es desplegà en terres d'oil, bé del rei de França o bé del rei d'Anglaterra, ${ }^{51}$ i en la bilingüe Bretanya, ducat que tenia la capital a Nantes. Entre el 5 i el 17 d'abril de 1417, fra Vicent és a Lió. En maig i juny és al Franc-Comtat. Després s'endinsa en la conca del Loira, passant per Nevers, Bourges, Tours i Angers, en direcció a la Bretanya, per una invitació insistent del seu duc, Joan V. Arriba a Nantes, el 8 de febrer de 1418. El 5 de març de 1418, és rebut a Gwened pels ducs Joan V i Joana de França, que volen assistir als seus sermons de quaresma (Le Dorze 2011: 52-67; Fàbregas 2019).

Tenim poques informacions sobre els sermons de mestre Vicent predicats després de la Quaresma de 1417, és a dir, des que ix de l'Alvèrnia fins que mor a Gwened. Probablement pertanyen a aquesta etapa alguns dels sermons del manuscrit llatí de la biblioteca de la Catedral de Pamplona amb sermons de mestre Vicent Ferrer, ja que s'hi observen fragments en francés en uns quants anuncis de la divisio thematis. Així, en la presentació de la divisio del sermó sobre el tema «Concluserunt piscium multitudinem copiosam», que és el número 110 de l’inventari de Perarnau (1999b: 522), llegim:

pono tres conclusiones: prima, quod purgatorium est sicut carcer de gens apresonnées, cum dicitur 'concluserunt'; secunda, quod in purgatorio vadunt solummodo personnes baptizées, cum dicitur 'piscium'; tertia, quod anime purgatorii sunt bien acompagnées, cum dicitur 'multitudinem copiosam?. 52

Un exemple semblant a l'anterior el podem llegir al núm. 823 del mateix inventari (Perarnau 1999b:773), pertanyent al mateix manuscrit de Pamplona: «Quatuor (...) sunt opera misericordie (...): donner liberelment, prester purement, torner plenement, servir doulcements ${ }^{53}$.

51 No es té confirmació documental del suposat desplaçament de fra Vicent a Caen (Normandia), a petició del rei Enric V d'Anglaterra.

52 Aquesta mateixa divisio sobre el mateix tema del sermó, però amb substitució de les frases franceses per les seues corresponents en català («de gents apresonades», «persones batejades», «que les ànimes del purgatori són bé acompanyades») es troba en el manuscrit vicentí 82-5-3 de la Biblioteca Colombina de la Catedral de Sevilla, i, en llatí, en l'edició de Colònia dels sermons de sant Vicent, de 1485. Ara bé, el manuscrit de Pamplona beu de fonts molt diverses, ja que conté exemples de la divisio thematis amb fragments en català i en castellà (Perarnau 1999b: 522, 524, 533).

53 El mateix esquema, però amb una formulació híbrida llatí/romanç, ja es trobava en el manuscrit de Perúgia: «(...): 
L'escassesa de notícies sobre els sermons vicentins d'aquesta darrera etapa missionera contrasta amb la riquesa informativa de les enquestes realitzades a Gwened en favor de la canonització de mestre Vicent Ferrer (1453-1454). Hi deposaren 313 testimonis. Crida l'atenció el net predomini de pescadors, menestrals i llauradors i l'alta presència femenina, que conforma més d'un terç dels enquestats. Les actes bretones del procés, tal com ens han arribat, no reprodueixen el qüestionari a què foren sotmesos els testimonis. Però la qüestió de la llengua usada pel nostre predicador hi té una notable rellevància, atés que el ducat de Bretanya es distribuïa llavors en tres àrees idiomàtiques, una bretonòfona, una altra francòfona i una altra bilingüe (Ferrando 1997). Gwened o Vannes era bilingüe, una situació sociolingüística ben reflectida en les actes bretones del procés de canonització. El fet que mestre Vicent evités predicar en les àrees exclusivament bretonòfones prou que posa de manifest que en les seues predicacions al laïcat en general usava una llengua romànica que pogués ser entesa.

Encara que la finalitat dels enquestadors sobre la llengua de la predicació de mestre Vicent anava dirigida a aconseguir que tots els enquestats reconeguessen que entenien els sermons del nostre predicador, l'anàlisi de les declaracions dels testimonis de Gwened referides a la llengua de la seua predicació permeten confirmar que aquesta era el francés, tal com expliciten directament o indirectament la majoria dels testimonis que s'hi pronuncien. Certament, hi ha uns quants testimonis que eludeixen identificar la llengua que emprava fra Vicent i n'hi ha alguns, molt pocs, que afirmen que també utilitzava el català o que l'alternava amb el francés. Encara que no es pot excloure que fra Vicent utilitzés ocasionalment alguna expressió de la seua llengua per donar vivesa a la prèdica cosa que podria justificar les afirmacions d'alguns testimonis-, aquest recurs en devia ser l'excepció, ja que, a diferència de Tolosa, el català no hi era comprensible. No hi trobem cap anècdota que n’avale l'ús, com és el cas de Tolosa. Ben al contrari, les paraules que pronuncià fra Vicent per curar un malalt, segons la declaració de Perrin Hervei, són en francés: «Mon fils, tu seras contostos brevi (sic)» (Esponera 2018: 62). Altrament, per molt bon francés que pogués usar fra Vicent, era evident que molts dels seus oients devien percebre que era un francés amb accent estranger. Alguns dels testimonis declararen que tenien dificultat per a entendre'l.

Els pocs testimonis bretons que afirmen que fra Vicent predicava en català són contradictoris i responen a un estat d'opinió prèviament construït. Difícilment podem esperar d'una gran part de la població de Gwened, repartida entre francòfons, britonizantes ('de llengua bretona') i bilingües franco-bretons, uns coneixements lingüístics suficients per a reconéixer quan el vulgar emprat per fra Vicent era una llengua catalana que desconeixien, o que n'alternava l'ús amb el francés.

Altrament, a les actes de Gwened, a diferència de les de Tolosa, ningú no parla de la doble denominació de la llengua i, quan s’informa sobre la pàtria de mestre Vicent, sempre es remet a València, una ciutat «de regno Aragonie» o «de partibus Aragonie». Només s'hi parla de «català» o de «vulgar d'Aragó», mai de «valencià». En altres mots, ha desaparegut la informació de primera

donare liberalment; prestare purament, reddere plenament; servire dolcamen丸» (Gimeno \& Mandingorra 2006: 336).

SCRIPTA, Revista internacional de literatura i cultura medieval i moderna, núm. 16 / desembre 2020 / pp. 71-130 ISSN: 2340-4841 · doi:10.7203/SCRIPTA.16.19213 
mà sobre la llengua i la pàtria del nostre predicador que hi havia a Tolosa: Bretanya era lluny de la Corona d'Aragó; la companyia de seguidors de fra Vicent s'hi havia reduït dràsticament; la llengua autòctona del país, el bretó, era totalment inintel ligible per als parlants de llengües romàniques, i a penes es tenia notícia del parlar matern del nostre predicador.

Heus ací una mostra representativa de la diversitat de respostes dels bretons enquestats. Una de les més adduïdes, precisament per la qüestió de la llengua, és la de Prigentius Ploeniguer (o Ploevinger), advocat de la Cúria eclesiàstica de Gwened, d'uns 65 anys d'edat, que confessà haver sentit fra Vicent predicar a la ciutat francesa d'Angers i, en la quaresma de 1419, a Gwened. En relació a aquestes últims predicacions, Ploeniguer fa notar que hi havia molta gent de les poblacions pròximes que acudien a escoltar-lo i que,

\begin{abstract}
licet ydioma cathalonicum quo uteb[atur] idem Magister Vincentius [intell]igibiliter sapere soliti non [fuissent], attamen, mediante [dulcedine] sue sermocinationis [eius ac signis] que faciebat [et nutu, ut] communiter ferebatur, [divino, omnes] fructum effectualem huiusmodi predicationum reportabant et retinebant. ${ }^{54}$
\end{abstract}

Òbviament, Prigentius repetia una opinió que s'anà construint sobretot en els anys posteriors a la mort del candidat a la santedat: que fra Vicent, malgrat utilitzar el català, era entés per tothom. Una construcció ideològica que, evidentment, pretenia avalar el miracle apostòlic del do de llengües. ${ }^{55} \mathrm{En}$ canvi, el testimoniatge de Pere Floch, ciutadà de Gwened, d'uns 50 anys d'edat, que acudí a les darreres predicacions de mestre Vicent a Gwened, desautoritza l'afirmació de Prigentius, ja que declarà que

\begin{abstract}
britones britonizantes, licet non intelligerent Galicum, intelligebant tamen, ut refferebat, eius predicationes. Et ipsemet testis vidit multos ignorantes linguam Gallicam qui effectualiter multas suas predicationes recitabant. ${ }^{56}$
\end{abstract}

És a dir, en la declaració de Pere Floch se sobretenén que predicava en francés. Res no es diu de l'ús del català. Alieta, esposa de Perrot Alleno, de Gwened, d'uns 60 anys d'edat, també declarà «quod etiam Britones Britonizantes et linguam Galicam ignorantes eum intelligebant», és a dir, 'que també els bretons de llengua bretona que ignoraven el francés l’entenien’ (Esponera 2018: 84). Si els bretons monolingües afirmaven que ignoraven el francés és perquè fra Vicent els predicava en francés, no en català.

54 Traducció: «encara que l’idioma català que usava mestre Vicent no fos conegut per molts, tanmateix, per la dolçor de la seua forma de parlar i els gestos que feia -que es consideraven divins en general-, tots treien fruit de la seua predicació, els agradava i la retenien» (Esponera 2018: 55). Fages llegeix Ploeviguer.

55 Sobre el procés de construcció d’aquest miracle i de les seues manifestacions posteriors, remet a Ferrando (2018).

56 Traducció: «que els bretons de llengua bretona, encara que no sabessen el francés, tanmateix entenien les seues predicacions. I el mateix testimoni conegué molts que ignoraven la llengua francesa i que així i tot repetien molt bé els seus sermons» (Esponera 2018: 75). En lloc de britonizantes, Esponera transcriu britonizatos.

SCRIPTA, Revista internacional de literatura i cultura medieval i moderna, núm. 16 / desembre 2020 / pp. 71-130 ISSN: 2340-4841 · doi:10.7203/SCRIPTA.16.19213 


\title{
Antoni Ferrando Francés. La poliglòssia en la predicació de Vicent Ferrer
}

En termes semblants s'expressà Alà Annoblan, d'Elven, de 50 anys i de llengua bretona, que havia sentit fra Vicent predicar només una vegada a Gwened, quan declarà que

\begin{abstract}
vidit dictum Magistrum Vincentium (...) in civitate Venetensi predicare; et quia testis ipse est Brito Britonizans nec bene intelligit Gallicum (...), perquisivit ab utramque ydioma Gallicum scilicet et Britonicum scientibus in dicta predicatione existentibus, quid ipse Magister Vincentius dixerat et predicaverat. ${ }^{57}$
\end{abstract}

La declaració del monolingüe bretó Alà és molt diàfana: li calia torcimany. En canvi, hi ha alguns testimonis que, intentant fer casar mite i realitat, converteixen en bilingües els sermons de mestre Vicent. Així, Simon Maydo, ciutadà de Gwened, de 50 anys, que assistí a sermons de fra Vicent predicats a Nantes i a Gwened,
deponit quod omnes astantes in suis missis et predicationibus tam Gallici quam Britones Britonizantes, etiam non intelligentes eius vulgare et Gallicum, multum proficiebant audiendo predicationes suas (...). Interrogatus quomodo scit quod Britonizantes sic intelligebant, respondit quod aliquando ipse testis a plurimus ignorans Gallicum, et etiam vulgare Aragoni[cum] (...), qui responderunt quod tam verbo quam signis suis ipsum bene intelligebant. (...) Scit etiam bene quod predicti Britonizantes ignorabant Gallicum et Catholonicum, quia eos cognoscebat. ${ }^{58}$

En aquest cas, la llengua de mestre Vicent esdevé indistintament «vulgare Aragonicum» i «Catholonicum», i les llengües en què predicava eren «eius vulgare et Gallicum». El mateix discurs de l'alternança de les dues llengües és assumit per Joan Hodierne, de llengua bretona, quan declara que «licet Gallicum et Catholonicum non intelligeret, intelligebat tamen effectualiter tam ex verbis quam modo proferendi et signis que faciebat idem Magister Vincentius predicaciones eius». ${ }^{59} \mathrm{En}$ canvi, el cavaller francòfon Enric Duval es limita a dir que «ipse et alii quamplurimi quasi omnes stantes intelligebant ydioma et vulgare suum», ${ }^{60}$ on el «vulgare suum» podria interpetrar-se com la llengua pròpia de fra Vicent, bé que no concreta si es referia al conjunt del sermó o a alguna expressió en català.

\footnotetext{
57 Traducció: «va veure Mestre Vicent (...) predicar a Gwened; però com que el testimoni és bretó de llengua bretona i no entenia bé el francés (...), s'assabentà, pels assistents a la predicació que coneixien la llengua francesa i el bretó, de allò que Mestre Vicent havia dit i predicat» (Esponera 2018: 245).

58 Traducció: «declarà que tots els assistents a les seues misses i sermons, tant els francesos com els bretons de llengua bretona, i fins i tot els que no entenien la seua llengua vulgar ni el francés, quedaven molt edificats escoltant les seues predicacions (...). Interrogat sobre com sap que els parlants de llengua bretona l'entenien, respongué que a vegades aquest testimoni preguntà a molts que ignoraven absolutament el francés i la llengua vulgar d'Aragó (...) i li respongueren que entenien perfectament tant les seues paraules com els seus signes (...). També sap bé que els esmentats bretons de llengua bretona ignoraven el francés i el català, perquè els coneixia» (Esponera 2018: 79).
}

59 Traducció: «encara que no sabia el francés ni el català, tanmateix l’entenia perfectament, tant per les paraules com per la manera de pronunciar-les i pels gestos que feia mestre Vicent en les seues predicacions» (Esponera 2018: 131).

60 Traducció: «ell i la majoria de quasi tots els presents entenien la seua llengua vulgar» (Esponera 2018: 58).

SCRIPTA, Revista internacional de literatura i cultura medieval i moderna, núm. 16 / desembre 2020 / pp. 71-130 ISSN: 2340-4841 · doi:10.7203/SCRIPTA.16.19213 
A pesar de les concessions que alguns testimonis feien al discurs interessat sobre l'ús del català o del «vulgar d'Aragó», que en tot cas havia de ser ocasional i com una estratègia comunicativa, el fet aclaparadorament evident és que fra Vicent usava normalment el francés per a fer-se entendre dels bretons francòfons i bilingües. I és només en francés que fra Vicent ensenyava les principals oracions del cristià, tal com va confirmar Joana, esposa de Rudolf Ruallant, de la diòcesi bilingüe de Saint-Briuec, en recitar en presència del seu enquestador el «Pater noster et Ave Maria in Gallico, quam sibi et pluribus aliis de partibus addiscit et docuit dictus Magister Vincentius». ${ }^{61}$

\section{Els sermons al regne de Castella}

Les recerques, ben conegudes, de Pedro Manuel Cátedra (1984; 1994) sobre la predicació castellana del dominic valencià ens estalvien ara d'insistir-hi. Només en recordaré les conclusions pel que a fa la llengua usada pel nostre predicador: l'anunci del pla de divisió dels sermons, la versió en romanç dels versicles bíblics citats i les expressions d'estil directe, és a dir, els trets temàticament i lingüísticament més significatius del sermó, apareixen generalment en «un discutible castellano lleno de aragonesismos» (Cátedra 1984: 284). Aquesta mena de llengua, que es desprén també de l'estudi de les petges castellanes i aragoneses dels manuscrits llatins del Patriarca i d'Aiora, és la llengua que usà el nostre predicador en terres del regne de Castella, incloent-hi òbviament el regne nominal de Múrcia. ${ }^{62}$

Ara que disposem de l'edició completa del manuscrit del Patriarca (Gimeno \& Mandingorra 2002), podem confirmar que el castellà amb nombrosos tocs d'aragonés subjau en la major part dels sermons, no sols en la traducció del tema i en l'anunci de la divisio thematis, sinó també en un bon nombre de mots i expressions de l'explanació del sermó. I també sabem que fra Vicent fou assistit durant la predicació castellana per fra Joan d'Alcoi i per fra Pere de Moya, dominicans potser procedents de la zona de llengua aragonesa del regne de València, que compartien amb ell la tasca pastoral de la predicació i, almenys en el cas de fra Joan d'Alcoi, la de reportador i traductor al llatí

61 Traducció: «és a dir, 'el Pater noster i l'Ave Maria en francés, que a ella i a molts altres d'aquelles parts havia ensenyat el citat mestre Vicent» (Esponera 2018: 149).

$62 \mathrm{El}$ manuscrit més útil en aquest sentit és el de del Patriarca de València. No hi ha consens acadèmic sobre l'autoria de la còpia: mentre Gimeno (1992: 82-83) defensa l'autografia de fra Vicent Ferrer, Perarnau (1999d: 402-406) sosté que és de diverses mans, entre les quals, la de fra Joan d'Alcoi, segons s'hi fa constar. En tot cas, aquest manuscrit es revela molt productiu per a discutir els difícils problemes de la transmissió textual dels sermons vicentins. Així, en la frase «Antichristus et finis mundi venient ajna et muyt aÿna» ('l'Anticrist i la fi del món vindran prest i molt prest') del sermó núm. 52, predicat a Chinchilla (Gimeno \& Mandingorra 2002: 222), observem que s'ha preservat en aragonés l'expressió aÿna et muyt aj̈na. En canvi, en la frase «Et sic, iudei, non decipiamini nam ista jornada tost et ben tost veniet» (' $\mathrm{I}$ aíxí, jueus, no us enganyeu perquè aquesta jornada arribarà prest i ben prest') del sermó núm. 16 del mateix manuscrit, predicat a Lorca (Gimeno \& Mandingorra 2002: 87), el mateix sintagma s'ha convertit en tost e ben tost. En aquest cas, és molt complex dilucidar si la tria d'una o d'altra expressió és fruit del reportador del sermó o de l'antígraf que hauria consultat el copista. 
dels seus sermons en castellà. Així, en el sermó núm. 3, predicat a Múrcia, Joan d’Alcoi no sols presenta el tema 'Reddet mihi Dominus in illa die, scilicet plenam retributionem' en aquests termes: «Illud verbum propositum loquitur de die iudici (...) dicens sic: Nostro Senyor, justo jutge, me dará plenaria retribución en aquell dia del iudicio universali, sinó que conserva en castellà l'anunci de la divisio thematis i la introducció a cada un dels subtemes (Gimeno \& Mandingorra 2002: 35). ${ }^{63}$

A costat del castellà, el copista del manuscrit del Patriarca també posa paraules o expressions en català. Cátedra les explica perquè el reportador, «presionado por la necesidad de no perder el hilo» de la narració, hauria preferit tirar al recte i recórrer al català. Hi ha exemples que ho suggereixen. Així es podria explicar, per exemple, la preservació del sintagma «rach de llum», que llegim en el sermó 10 del nostre manuscrit, predicat a Múrcia: «descendit un rach de llum et posuit se super caput Matie» (Gimeno \& Mandingorra, 2002: 56). Però també ho podria fer per fidelitat a una expressió realment usada per fra Vicent. Exclamacions com «bona gent» $\mathrm{O}$ «mes filles» es reiteren en sermons predicats en els més diversos indrets de les terres castellanes. Així en el sermó núm. 6, predicat a Múrcia, llegim: «vos, mes filles, nutriatis vestros pueros ut non jurent nomen Dei» ('vosaltres, filles meues, eduqueu els vostres fills perquè no juren en nom de Déu') (Gimeno \& Mandingorra 2002: 45). I en el sermó núm. 173, predicat a Simancas, també trobem la mateixa exclamació: «alia dieta est non occidere neque vindictam, neque pro furando, neque pro ocultando pecatum, mes filles) ('un altre comportament és no matar, ni venjar-se ni per a furtar ni per a ocultar el pecat, filles meues') (Gimeno \& Mandingorra 2002: 756). Certament, aquesta mena d'exclamacions podrien ser un recurs de fra Vicent per a cridar l'atenció, però és més probable que siguen collita dels reportadors ${ }^{64}$. En tot cas, no hi ha cap sermó, ni cap document arxivístic, cronístic o literari que avale l'ús, ni tan sols esporàdic, del català en els sermons de mestre Vicent predicats a Castella (Ferrando 2013b).

Convé advertir, però, que en el manuscrit del Patriarca no són iguals el nombre i el tipus de catalanismes presents en els sermons predicats a Múrcia que en els predicats a la Castella estricta. Als sermons castellans són molt esporàdiques les expressions del tipus «bona gent»o «mes filles» i a penes trobem cap frase en català. En canvi, aquestes expressions i frases en català abunden en la predicació murciana. Així, en el sermó núm. 5, pronunciat a Múrcia el gener de 1411, veiem integrada en l'oració «Non autem comeduntur in Paradiso res corporales corruptibilis ut lat, e mel e mantega sicut dicunt sarraceni» ('tanmateix, en el paradís no es menjaran coses corruptibles com la llet, la mel i la mantega, tal com diuen els sarraïns') (Gimeno \& Mandingorra 2002: 41), una expressió romànica, quasi catalana, «lat, e mel e mantega», que s'atribueix als moros. El pes del

63 Perarnau (1999d: 401) creu que el copista «potser era aragonès o de la zona castellana del País Valencià», perquè «escriu frases en castellà, sempre però amb grafia catalana» (com jutge o com el recurs sistemàtic al dígraf ny), però era també catalanoparlant, precisament per aquestes mateixes raons i perquè, en paraules de Perarnau, «la lletra del volum és gòtica catalana cursiva semibastarda».

64 Hi ha, però, algun cas de mot comú escrit en català que suggereix una distracció del copista. N’és un exemple repòs, que apareix per reposo en la frase «Nam sabbatum vult dicere repòs», del sermó núm. 124, predicat a Ocaña (Gimeno \& Mandingorra 2002: 458). 
català col loquial també s’observa en el sermó núm. 11, així mateix predicat a Múrcia, en frases com «non poterint habere nisi un troc de pa» ('no podrien tenir ni un tros de pa') o com «maledicta est persona que comedit carnem in Quadragesima!, nam magis sibi valeret quod comederet caliu e plom regualat. Et ideo, debet providere ut non fierent carnes nisi pro infirmis, scilicet, cabrit e corder, non multones et perdices» ('maleïda siga la persona que menja carn en Quaresma, ja que més li valdria menjar caliu i plom fos. Per això cal procurar que només es preparen carns per a malalts, com és cabrit i corder, però no moltons i perdius') (Gimeno \& Mandingorra 2002: 63 i 64), on observem preferències lèxiques valencianes (plom regalat i corder en lloc de plom fos/colat i anyell). Quan en el sermó núm. 12, predicat a la vila murciana de Libriella, llegim que Déu recomana «quod non pintent se mulieres las cellas, et quod frangant las boxetas vel capcetas del blanquet, et quod non portent faldas» ('que les dones no es pinten les celles, i que trenquen les boixetes o capsetes del blanquet $\mathrm{i}$ que no porten faldes') o, quan en el mateix sermó, llegim «hoc est per comunionem in qua datur quidam pullus delicatus e tendrellet, scilicet Ihesus Christus, natus de la lloca e guallina beate Marie» ('això és per la comunió, en què es dona un pollastre delicat i tendret, és a dir, Jesucrist, nascut de la lloca i la gallina de santa Maria') (Gimeno \& Mandingorra 2002: 68 i 69), sembla que el predicador està reproduint uns mots susceptibles de ser coneguts entre els seus oients. Són una mena de catalanismes, possiblement reals en boca de fra Vicent mentre predicava a Múrcia, que difícilment trobem en els sermons predicats a la Castella estricta. Però no es pot excloure que fossen el resultat de la consulta pel copista d'una versió catalana dels sermons abans de ser traduïts al llatí.

La raó de la diferent presència d'expressions i frases catalanes en els sermons murcians i en els sermons estrictament castellans podria raure en el fet que fra Vicent devia saber que el castellà de Múrcia conservava a principi del segle XV un altíssim nombre de catalanismes, com a conseqüència de la colonització catalana i valenciana de finals del segle XIII i començament del XIV, i on era probable que encara persistissen minories amb una competència passiva del català. Però hi havia sobretot un altre fet que no devia desconéixer el nostre predicador: l'alta incidència de la immigració de valencians a Múrcia en temps de mestre Vicent Ferrer. Hui sabem, gràcies als estudis de Denis Menjot (1975: 235), que més d'una tercera part dels immigrants valencians a Múrcia durant el període de 1370 a 1420 procedien d'Oriola i de les localitats catalanòfones pròximes. Conscient d'aquesta situació, és probable que mestre Vicent s'hi sentís més lliure per a usar alguns catalanismes. En tot cas, les peculiaritats del parlar murcià d'aquella època podrien ser suficients per a explicar la presència d'un bon nombre de catalanismes en la predicació murciana de fra Vicent, especialment si descendia a l'àmbit de l'exemplum. ${ }^{65}$

Mestre Vicent no coneixia el portugués. És probablement per aquesta raó que no va estendre la seua tasca missional a Portugal. Encara que Justinià Antist invocà en la seua biografia del nostre predicador una tradició relacionada amb la suposada presència de fra Vicent a Galícia, acceptada acríticament per Sanchis Sivera (1932: I, 13), aquesta tradició manca del més mínim fonament

65 En temps actuals, encara és possible sentir expressions en llengua catalana entre els murcians que conserven els trets característics del seu parlar, altrament molt influït pel valencià.

SCRIPTA, Revista internacional de literatura i cultura medieval i moderna, núm. 16 / desembre 2020 / pp. 71-130 ISSN: 2340-4841 · doi:10.7203/SCRIPTA.16.19213 
documental, la qual cosa confirma una vegada més que fra Vicent es limità a predicar en els terres romàniques la llengua de les quals dominava.

\section{Els sermons als territoris hispànics de la Corona d'Aragó}

Mestre Vicent dugué una impressionant tasca missional en els territoris hispànics de la Corona d'Aragó entre gener de 1409 i gener de 1416, a excepció dels catorze mesos llargs que passà en terres castellanes (1411-1412). Riera (2013: 419-427) n'ha reconstruït l'itinerari. Ara l'aprofitaré, sintetitzant-lo i omplint-ne alguns buits, per a donar compte de la producció homilètica coneguda que fra Vicent va generar en cada etapa del seu itinerari hispànic i per a destacar les seues coincidències amb els reis Martí l'Humà i Ferran I i amb el papa Benet XIII.

El predicador valencià arriba a Perpinyà, procedent de Montpeller, a la darreria de 1408. Predica per moltes poblacions de tot Catalunya (Elna, Girona, Vic, Manresa, Lleida, Tarragona, Tortosa, etc.) fins que l'abril de 1410 passa al regne de València. A Barcelona coincideix amb el rei Martí $i$ amb el papa Benet.

Des d'abril de 1410 fins a gener de 1411 recorre tot el regne de València, des de Morella fins a Oriola (Sant Mateu, Castelló, Vila-real, València, Xàtiva, Alacant, Elx, etc.). D’aquesta etapa és un sermó sobre la predestinació predicat, el 24 de juliol de 1410, a València, que va publicar Felip Mateu i Llopis.

A mitjan gener de 1411 comença a Múrcia el seu itinerari pels dominis del rei de Castella (Lorca, Chinchilla, Albacete, Ciudad Real, Toledo, Valladolid, Tordesillas, Medina del Campo, Salamanca, Zamora, Plasencia, Segòvia, etc.), que no acabarà fins a la darreria de març del 1412, en què passa a Terol per a dirigir-se a Casp. A Ayllón (Segòvia) coincideix amb el jove rei Joan II de Castella i amb sa mare, la reina Caterina de Làncaster. Cátedra (1994) edità els trenta-cinc sermons en castellà d'aquesta etapa que es conserven en el Ms. 294 de la Real Academia Española, copiat el 1448. Ja hem vist també que el manuscrit del Patriarca conté 185 sermons en llatí amb la predicació de mestre Vicent per terres castellanes (Perarnau 1999d; Gimeno \& Mandingorra 2002).

Cridat a formar part de la comissió designada per les Corts valencianes per a decidir amb els representants de Catalunya i d'Aragó sobre la successió de Martí l'Humà, mestre Vicent Ferrer arriba a Casp a mitjan mes d'abril de 1412. Resolta, en l'anomenat Compromís de Casp, la successió a la Corona d'Aragó a favor de Ferran el d'Antequera, fra Vicent continua la tasca missionera per l'Aragó meridional (Alcanyís, Daroca, Terol) fins més enllà de mitjan octubre, sota la mirada atenta de Benet XIII, llavors ja instal lat a Peníscola. D’aquesta etapa és el sermó que predicà a Alcanyís el 27 de juliol de 1412 davant Benet XIII. Ja hem avançat que alguns dels sermons llatins amb petges en castellà o aragonés posteriors al sermó d'Alcanyís del manuscrit de Perúgia deuen correspondre a la predicació aragonesa de fra Vicent d'aquesta etapa. Se sap que tot el temps que fra Vicent sojornà a Casp, entre el 12 d'abril i el 28 de juny, hi predicà cada dia. Si la predicació era destinada al laïcat, és de suposar que fou en llengua aragonesa. Tanmateix, el dia 28 de juny, en el sermó de la missa 
d'acció de gràcies per l'elecció de l'infant Ferran de Castella com a nou rei de la Corona d'Aragó, fra Vicent convidà els assistents a saludar la decisió amb un «Viva, viva nostre rey e senyor don Ferrando», en llengua catalana o valenciana, per dir-ho amb la mateixa fórmula que utilitzaren els tres compromissaris valencians per a relacionar-se simultàniament amb els parlaments de València i de Catalunya (Gimeno 2013; Ferrando 2013a).

En novembre de 1412, mestre Vicent passa al regne de València pel camí que baixa de Terol a Morvedre. Entre novembre de 1412 i mitjan abril de 1413, centrà la seua activitat missionera a la ciutat de València i a les poblacions pròximes. Els quatre volums de les Reportationes sermonum Reverendissimi Magistri Vincentii Ferrarii (actuals Mss. 276 a 279), ${ }^{66}$ de ca. 1428, i el manuscrit Sermons de Sant Vicent Ferrer. Quaresma de 1413 (Ms. 273), de ca.1458, conservats a l'ACV, reprodueixen un bon nombre de sermons predicats en aquest període (juny de $1412 \mathrm{a}$ abril de 1413). Concretament, els 53 sermons de la Quaresma de 1413 van ser predicats a València entre el 5 de març i el 26 d'abril.

A la darreria d'abril de 1413, mestre Vicent ix de la ciutat de València camí de Barcelona. És a Tortosa entre el 24 de juny i el 9 de juliol, on coincideix amb Benet XIII. És a Barcelona entre el 21 de juliol i el 25 d'agost, en què salpa cap a Mallorca, acompanyat per Antoni Anglada, Juan García i Joan Placentis (Rosselló 2018: 11-14). Els manuscrits 476 i 477 de la Biblioteca de Catalunya, del segon terç del segle XV, arrepleguen, en llatí o en català, una seixantena de sermons vicentins predicats majoritàriament en el transcurs del viatge de València a Barcelona (Morvedre, Borriana, Vila-Real, Onda, Sant Mateu, Benicarló, Tortosa, Tarragona, etc.) i en la capital catalana (Perarnau 1985; 1996). Els recollits en català són només onze.

L'1 de setembre de 1413, ja és a la Ciutat de Mallorca. A l'illa predica fins al 20 de gener de 1414. El manuscrit d'Avinyó arreplega la versió llatina d'aquesta predicació, amb una indicació precisa de la major part dels llocs de predicació (Ciutat de Mallorca, Sóller, Inca, Pollença, Muro, Manacor, etc.). Però reprodueix també versions llatines de sermons predicats a Castella i Aragó (1412-1415), ja que des del núm. 2 constatem la preservació de mots en castellà o aragonés.

Tot seguit, fra Vicent retorna a Catalunya, on s'està de gener a abril de 1414. La major part d'aquest temps predica a Lleida, on coincidí amb el rei Ferran I, i a les poblacions més importants de les comarques veïnes. Concretament, la predicació lleidatana de fra Vicent, corresponent a la quaresma i a la pasqua de 1414, amb vint-i-un sermons, està recollida, en llatí, en el manuscrit d'Aiora.

Durant els mesos de maig i juny de 1414, fra Vicent recorre Aragó (Tamarit, Aïnsa, Jaca, Alcanyís), i coincideix a Saragossa amb el rei Ferran I. Un dels testimonis enquestats a Tolosa amb motiu del procés de canonització de fra Vicent, Juan Ximén de Buerba, natural de Aïnsa (diòcesi d’Osca),

66 El Ms. 277 de l'ACV desaparegué en els anys de la guerra civil espanyola (1936-1939). Devem a Perarnau (1984) una proposta de reconstrucció del Ms. 277 a partir de les descripcions i transcripcions de Sanchis Sivera i dels fragments publicats. Constava de 54 sermons: de l'1 al 40, corresponents a les darreres setmanes després de Pentecostés i a l'Advent, van ser predicats a Saragossa (conserven alguns mots en aragonés, com domingo); del 41 al 54, corresponents a Nadal, van ser predicats a València. 
dona compte dels miracles que hauria obrat el dominic valencià els onze dies que va estar en aquella població (encara que en situa l'estada en juliol), acompanyat per «les dones i els homes valencians de la seua companyia» (Esponera 2018: 473). Entre els miracles adduits pel testimoni, no ni ha cap referit a la llengua de la predicació de mestre Vicent, que allí hauria estat en aragonés.

Des de principis de juliol a la primera meitat de setembre de 1414, mestre Vicent Ferrer i el rei Ferran coincideixen a Morella, i, des de finals de juliol a principis de setembre, s'hi afegeix el papa Benet XIII. També hi acudeixen els ambaixadors de l'emperador Segimon d'Hongria. L'objectiu d'aquelles vistes era trobar una deseixida al Cisma d'Occident. Durant dos mesos i mig, Morella es convertí en certa manera en la capital política i religiosa de la Corona d'Aragó i de la política europea. Des de Morella, fra Vicent degué fer diverses eixides missionals als pobles pròxims, en algun cas potser en coincidència amb el rei, que per aquelles dates visitava Alcanyís i Casp. Durant la guerra civil de 1936-1939, van desaparéixer de la biblioteca de l'església arxiprestal de Morella els quatre manuscrits que contenien sermons de mestre Vicent, entre els quals hi havia una desena en llengua catalana. Segons Perarnau (1984: 39), «l'aplegador de les peces vicentines dels mss de Morella tenia un interès apocalíptic innegable». D'aquests sermons, només en coneixem els dos que publicà mossén Manuel Betí. Sembla que ha reaparegut un dels quatre manuscrits.

De nou a l'Aragó, hi sojornà de mitjan setembre de 1414 a finals de juliol de 1415, sobretot a Saragossa, però amb algunes eixides a poblacions del migjorn aragonés, com Daroca i Terol. És de notar que, mentre fra Vicent desplega la seua tasca missional a Saragossa durant aquest període, on coincideix amb l’infant Alfons, el futur rei Magnànim, visiten València el rei Ferran i el papa Benet.

De Saragossa, fra Vicent es dirigeix a Perpinyà, passant per la Seu d'Urgell i Vilafranca de Conflent (agost de 1415), evitant així de travessar les principals poblacions del principat de Catalunya. El setembre ja és Perpinyà, on també han arribat el rei Ferran i Benet XIII. El gener de 1416, celebrada la conferència de Perpinyà, abandona definitivament les terres catalanes i es dirigeix a Narbona i Carcassona per a arribar a Tolosa el 10 d'abril.

En resum, fra Vicent distribuí les seues estades en terres hispàniques aproximadament així: 26 mesos a Catalunya, 20 a Aragó, 19 a València, 14 a Castella i quasi 5 a Mallorca. Ja hem vist que la major dels sermons conservats en català i castellà de fra Vicent pertanyen al període de 1411 a 1415.

Els manuscrits vicentins de l'ACV, amb 274 sermons en català, contenen el 94\% de la predicació vicentina en llengua catalana que ens ha pervingut. Crida l'atenció l'absència de sermonaris en aragonés de fra Vicent i l'escàs nombre de sermons en català conservats a Catalunya, 11 en total, que suposen menys del 3'5\% del nombre de sermons que ens han arribat en llengua catalana. ${ }^{67}$

67 Hi ha encara alguns sermons atribuïts a mestre Vicent de paternitat discutible. Daileader (2019: 297-306) fa un resum de l'estat de la qüestió. El Ms. 1095 de la Bibliothèque de Marseille conté sermons en català, alguns del quals podrien ser de mestre Vicent (Brunel 1934). Ho deu ser, en concret, el núm. 7, que duu un dibuix representant un frare, amb la subscripció «De ffrare Vicent Fferrer», segons M. Rodrigo (1985: 25), llegida erròniament per Brunel com «De ffrare Vicent Esteve». 
Ja hem vist que els quatre volums de les Reportationes sermonum Reverendissimi Magistri Vincentii Ferrarii copien sermons predicats majoritàriament entre 1412 i 1418. Els trets lèxics valencians de les Reportationes i la ubicació antiga d'aquests manuscrits a València suggereixen que molts d'aquests sermons hi haurien estat predicats. Concretament, aquests quatre volums i el Ms. 273 foren llegats testamentàriament a la Seu de València pel seu canonge Guillem Serra (ca. 1397-1489) (Rodrigo 2016: 168). Ara bé, tal com ja va advertir Chabàs (1903) i s'ha constatat, molts d'altres també es predicaren a França, a Castella i a l'Aragó. En efecte, la presència d'exclamacions i mots en castellà o aragonés en la predicació llenguadociana de mestre Vicent recollida en els esmenats manuscrits, com ara «por el cuerpo»; «La terça plaga fo mosquits... Veus ací los mosquitos, que no parlen sinó de la terra»; «les dents e ls colmillos»; «màxime lo domingo, car així com en la setmana, per los negocis temporals matinam, així lo dicmenge nos devem llevar tost», ja adduïts per Riquer (1964b: II, 263), posa de manifest que els copistes d'aquests manuscrits van consultar reportacions prèvies en castellà o aragonés. El mateix Riquer (1964a: 166) ja va advertir que, tot i que en algun d'aquests sermons predicats a Occitània es fa referència al «rey de França» (sermó VI), la major part de les vegades s'al ludeix al «rey d'Aragó» (sermons XVI i XXXIII), que no hi fa sentit, la qual cosa apunta que el nostre predicador s'hi basà en sermons previs en aragonés o castellà. Els calcs que en revelen la dependència són molt obvis quan es tracta de frases senceres, segons ha fet veure Jordi Colomina (2019), a propòsit del Sermó de les set arts (Sanchis Sivera 1934: II, 303-322), que és una traducció del Sermón de las siete artes, predicat en castellà a Salamanca, el 7 de març de 1412. Així doncs, a Occitània mestre Vicent es degué limitar a aprofitar i actualitzar resums de sermons ja predicats anteriorment en català, castellà i aragonés, però utilitzant l'occità.

Crec que puc provar que pràcticament tot el volum III i els set primers sermons del volum IV dels Sermons de fra Vicent, editats per Schib (1975 i 1977), corresponen a la predicació aragonesa de fra Vicent de 1412. En total són 35 sermons, que van del 10 d'agost de 1412, dimarts, dia de sant Llorenç, al dia 22 de setembre de 1412, dijous, amb molta probabilitat que també s'hagen predicat a Aragó els set primers del volum III (a partir del 3 d'agost) i potser algun més després del 22 de setembre (Ms. 278, de l'ACV). En el sermó del dia de sant Llorenç, fra Vicent recorre a unes referències locals molt concretes (castell d'Ollereta, bisbat d'Osca, Saragoça), sobretot quan introdueix aquesta «semblança»:

Dos hòmens són en aquesta vila, e han-se a mudar en altra vila. E anant de ací a Saragoça, haveu a passar per hun pas ple de ladres, que tots quant hi passen són robats. Donchs, com ó faran? Si ls porten ab si, seran robats. Ha-y remey: que, si en aquesta vila ha taula de cambi, fareu aquí lo cambi, e dar-los vos ha a Saragoça (Schib III, 1975: 69).

El dia 22 de setembre de 1412 és quan fra Vicent adreça als serrans amb aquella coneguda frase, que llegim al Ms. 278 de la Seu de València:

Semblantment en persones humanals; en vosaltres de la Serrania, qui estats enmig de Castella e de Catalunya, e per ço prenets algun vocable castellà e altre català. Axí és declarada la nostra regla: 'Omne medium', etc. (Schib, IV, 1977: 64).

SCRIPTA, Revista internacional de literatura i cultura medieval i moderna, núm. 16 / desembre 2020 / pp. 71-130 ISSN: 2340-4841 ·doi:10.7203/SCRIPTA.16.19213 
Fra Vicent s’interessava i coneixia quines eren les característiques del parlar de la Serrania ${ }^{68}$ que situa entre Castella i Catalunya.

Val la pena detenir-se en aquesta frase del sermó de la «feria V» de després de la «Dominica XVI post Trinitatem» de les Reportationes de la Seu de València, ja que una lectura precipitada de la frase ha dut a considerar que el sermó anava adreçat als habitants de la Serrania valenciana. ${ }^{69}$ Tanmateix, una lectura contextualitzada no permet altra interpretació que fra Vicent s'hi referia a la Serrania del sud del regne d'Aragó. ${ }^{70}$ En efecte, atesa la seqüenciació litúrgica d'aquesta secció del manuscrit, que examinaré més avant, el sermó adreçat als serrans en una fèria $\mathrm{V}$ (dijous) hagué de ser predicat, segons la cronologia litúrgica de Cappelli (1930: 60-61), el 22 de setembre de 1412, dijous, és a dir, després de la festa de sant Mateu (21 de setembre) i abans de la de sant Miquel (29 de setembre). En conseqüència, el sermó In octava nativitatis beate Marie, que és datat explícitament el 1412, segons ja observà Schib (1976: 335), hagué de ser predicat el 15 de setembre de 1412. I, com que sabem que fra Vicent era a l'Aragó el setembre de 1412, la Serrania a què es referia fra Vicent només pot ser la de l'Aragó meridional. ${ }^{71}$ Ho deduïm també per exclusió, ja que sabem que fra Vicent era a Mallorca el setembre de 1413, a Morella el setembre de 1414 i a Perpinyà el setembre de 1415 (Riera 2013: 421-426).

Entre el 10 d'agost i el 22 de setembre de 1412, la seqüència litúrgica de les Reportationes de la seu de València és cronològicament exacta. Són uns quants els sermons que remeten a d'altres, com ara

68 Una altra mostra eloqüent d'aquesta sensibilitat pastoral és la citació de la frase: 《lat, e mel e mantega sicut dicunt sarraceni» que havia pronunciat fra Vicent en un sermó predicat a la ciutat de Múrcia el gener de 1411, a la qual ja hem al ludit més amunt.

69 És una interpretació defensada per Joan Fuster i Sanchis Guarner, que Ferrando \& Nicolás (2011: 104) vam admetre acríticament i que ara rectifiquem.

70 La porta dels Serrans i el carrer dels Serrans de la ciutat de València reben aquests noms perquè és en aquest indret on s'establiren els serrans procedents del sud d'Aragó, sobretot de Terol. La colonització aragonesa d'aquestes terres meridionals del regne d'Aragó, conquistades per Alfons II d’Aragó i I de Barcelona, rebé contingents castellans, navarresos i catalans. Amb aquests elements i la influència de l'àrab dels mudèjars autòctons es conformà una varietat aragonesa singular, que explica que fra Vicent el considerés un parlar mig castellà i mig català. La colonització aragonesa d'algunes poblacions de l'interior del regne de València pròximes a Aragó, que reberen la influència afegida del català parlat al regne de València, també explica que els seus habitants rebessen el nom de serrans. Mateu Rodrigo m’ha comunicat que el seu Diplomatari de la Unió del Regne de València (Rodrigo 2013: 271) recull un interrogatori, de 19 de desembre de 1348, segons el qual es preguntà a un testimoni si sabia «qui eren los dits hòmens [tot just degollats] ne d'on eren, e dix que no ss sabia, mas dix que en serrà parllaven». Hi havia, doncs, consciència d'un parlar serrà. Òbviament, la Serrania valenciana és una prolongació de l'aragonesa, però no està entre Castella i Catalunya.

71 El sermó de la fèria $\mathrm{V}$ adreçat als serrans (22 de setembre, dijous) no té res a veure amb la vuitava de la Nativitat de santa Maria (15 de setembre, dijous). El copista del sermó als serrans es limità a reproduir al final aquests mots: «Prechvos... (recurre supra in fine sermonis octave nativitatis sancte Marie, ubi tale signum est: g-o)» (Schib IV, 1977: 65, que erròniament transcriu: sermonibus octabarum), on reenvia a l'oració final de la vuitava de la Nativitat de santa Maria (Schib III, 1975: 311). El problema és que el copista no ha reproduit l'oració final a la qual remeten, que començaria amb «Prech-vos». 
el del dia de l'Assumpció, dilluns, 15 d'agost, que fa: «dic ut supra in sermone Ascensionis Domini et in alio sequenti de similitudine» (Schib III, 1975: 121). I són uns quants els sermons que fan referència a l'Aragó, com ara el de divendres, dia 16 de setembre, que fa una al lusió a les ànimes sobre les quals ha de retre compte «lo arquebisbe de Saragoça» (Schib IV, 1977: 14) i, concretament, a l'Aragó meridional, com és el cas del sermó del dia 20 de setembre, on es diu: «Di, qui vol anar a Terol, la hun camí és pedregós e moltes costes, l'altre camí és pla, no y ha pedres. No serie gran follia de anar per lo camí pedregós?» (Schib IV, 1977: 46). ${ }^{72}$ També en aquests sermons hi ha un bon nombre d'aragonesismes, com ara asna, bando, barriga, clèrigo, galgo, moço, nòvio, onso, pico, quedo, rana, sanyós, tomar, trigo, vellaco (Casanova 2008: 41-42).

El reportador d'aquesta secció aragonesa deu ser una persona bilingüe de la zona del Baix Aragó o dels voltants, que anota directament en català, amb certs trets del seu parlar, la predicació en aragonés de fra Vicent. Ho suggereix no sols l'esmentat sermó als serrans aragonesos, sinó també els termes aragonesos que no tradueix. Entre les petges locals del català del reportador hi ha la no pronunciació de la - $r$ final («l'emperadó», III, 68), els subjuntius en -o («iquè fa lo evangeli de huy a la festa present, com parlo de santa Marta e de santa Maria Magdalena?, III, 74), i els subjuntius en -essa («Per ço que $t$ decebessa», II, 177). El reportador devia ser dominic, ja que, com advertí Perarnau (1984: 38), el compilador de les Reportationes de la Seu de València va substituir el calendari litúrgic dominicà de l'antígraf pel general. De fet, la conservació en els quatre volums de les Reportationes d'un cert nombre d'aragonesismes o castellanismes sembla indici d'altres sermons predicats a l'Aragó, dada que s'adiu bé amb l'observació del mateix Perarnau (1984: 39) que el reportador dels sermons de la Seu de València i, en general, els «seguidors apocalíptics de mestre Vicent tingueren una predilecció especial pels sermons de Saragossa». En tot cas, la preservació dels trets dialectals descrits i la naturalitat expressiva de la llengua emprada posen de manifest que el compilador d'aquests manuscrits es degué basar en un antígraf en llengua catalana.

Sabíem que fra Vicent era el 27 de juliol de 1412 a Alcanyís i el 15 d’octubre del mateix any a Terol, després d’haver estat a Daroca. Ara, gràcies a la identificació de la predicació aragonesa de fra Vicent, podem confirmar que el dominic valencià, després d'eixir de Casp, estigué a Aragó entre juny i octubre de 1412. ${ }^{73}$ També el Ms. 477 de la Biblioteca de Catalunya aporta informacions sobre la predicació aragonesa de fra Vicent. Perarnau explica «la presència de paraules o de frases castellano-aragoneses» en el sermó llatí sobre el tema 'Ego dispono vobis sicut disposuit michi Pater' d'aquest manuscrit precisament perquè hauria estat predicat en terres aragoneses el 23 de juliol de 1412 (citat per Cátedra, 1994: 125). Perarnau reconeix, per tant, que fra Vicent s'adaptava

72 Schib (1976:335) ja va advertir que al Ms. 278 hi ha unes «al lusions geogràfiques que es refereixen a Catalunya, Aragó i València» i esmenta l'aparició dels noms de Saragossa, València i Barcelona, però no relacionà els sermons d'aquest manuscrit amb la predicació aragonesa de l'estiu de 1412.

73 Es troba a faltar una recerca arxivística sobre l'itinerari i les petges de la predicació aragonesa de mestre Vicent Ferrer. Amb aquesta identificació s'ha omplit el buit cronològic més important de l'itinerari hispànic vicentí publicat per Riera (2013). 
lingüísticament a l'audiència. En efecte, el nostre predicador era a Alcanyís el 22 de juliol de 1412 (Riera 2013: 423) i també hi era el 27 del mateix mes (Gimeno \& Mandingorra 2006: 562). Per tant, sembla que el sermó del 23 de juliol el va predicar en aquesta població.

Ara bé, la millor informació sobre l'aragonés que coneixia fra Vicent ens la donen els manuscrits llatins i castellans de la seua predicació castellana (1411-1412). És ací que hem de buscar les petges, sobretot lèxiques (muyt, entaca, esti, sins, onso, gemecar, etc.) del seu aragonés. Només que caldrà no excloure-hi la mà dels copistes.

Perarnau (1984: 41) ja va deixar ben establit que els sermons del perdut Ms. 277 es van predicar a València entre el 19 de desembre de 1412 i l'1 de gener de 1413, i a Saragossa entre el 13 de novembre i el 23 de desembre de 1414. De fet, el 6 de novembre de 1414, mestre Vicent ja era a Saragossa, perquè, el dia 7, l'infant Alfons, des de Saragossa, adreçava una carta al seu pare, el rei Ferran I, dient-li que havia estat «ir dimars en la missa que maestre Vincent celebrave» (López 2004: 333). Entre els sermons del Ms. 277, n'hi havia un en què s'indicava que havia estat predicat a Saragossa (Schib 1976: 336). En un altre d'aquests sermons, salvat per una còpia a mà de Sanchis Sivera, es fa un referència molt concreta a l'estada aragonesa del nostre predicador: "per allò hagués tantost pluga en tot lo regne de València, e en Aragó se moren de set, que yo o sé» (Schib VI, 1988: 255), és a dir, que fra Vicent hi constata personalment aquest desastre humà. Schib (1976: 335) fa notar que al foli 125, que copiava el sermó del primer diumenge d'Advent, es llegia: «Aparellau-vos, ja ha XV anys e entram en el XVI que vayg per lo món a avisar-vos». Com que fra Vicent havia iniciat la seua tasca missional el 1399, Schib conclou que aquest sermó s'ha de datar el 1414. I com que ara sabem que, el primer diumenge d'Advent de 1414, fra Vicent era a Saragossa, podem deduir que és ací on el va predicar. En canvi, en el cas del sermó de sant Silvestre (Schib VI, 1988: 245), es fa constar: «Fet en València any MCCCCXIIII». La data i el lloc estan equivocats, ja que el 31 de desembre de 1414, dia de sant Silvestre, fra Vicent continuava a Saragossa.

La versió catalana, que no la traducció catalana, dels manuscrits de la Seu de València ha tingut la virtut de conservar molts trets de l'oralitat vicentina, que trobem a faltar en les versions llatines, concebudes més aïna amb el criteri de fixar, preservar i difondre el llegat vicentí més enllà de les fronteres locals. En alguns casos, conservem una versió catalana i una altra llatina del mateix sermó, que solen ser útils per a l'estudi de la transmissió dels sermons vicentins (contingut, llengua, etc.). Així, en el vol. II dels Sermons valencians editats per Sanchis Sivera (1934: 243-259) figura la «Col lació feta en la Seu de Mallorqua a preveres e religiosos», que trobem en llatí, amb fragments en català, en el manuscrit d'Aiora (Robles 1995: 397-416). En aquest manuscrit d'Aiora (Robles 1995: 333-394) es copien així mateix en llatí alguns sermons que apareixen en català en la Quaresma valenciana de fra Vicent (Sanchis Sivera 1927; Sanchis Guarner 1973). 


\section{1. «Lingua catalana sive valentina»: una qüestió entre la filologia i la història social de la llengua}

La llengua usada per fra Vicent en els sermons en llengua materna s'ajusta bàsicament al català general. Ja ho va posar de manifest Gret Schib (1977) a partir d'un buidat lèxic dels Mss. 276, 278 i 279 de l'ACV, i ho han confirmat Emili Casanova (2008), amb un estudi lingüístic dels mateixos manuscrits i de la Quaresma valenciana de 1413, i Jordi Colomina, amb el seu exhaustiu estudi gramatical i lèxic dels sermons vicentins (2021).

Ja hem vist que aquell català general, molt unitari, rebia entre els valencians, a principis del segle XV, el nom de valencià, denominació que els mateixos valencians en contextos internacionals alternaven amb el nom més general de llengua catalana, que era, al capdavall, la denominació única que usava la Cancelleria reial en adreçar-se simultàniament als territoris que la tenien com a llengua pròpia (Ferrando \& Nicolás 2011: 165-167). Mestre Vicent, com a representant més prestigiós de la delegació valenciana en l'anomenat Compromís de Casp, podria haver estat l'inductor de la fórmula «idiomate cathalano seu valentino» usada en la comunicació als parlaments de València i de Catalunya anunciant-los la pròrroga de les sessions de deliberació. ${ }^{74}$ En tot cas, és la mateixa fórmula que també veurem usada per alguns testimonis tolosans en el procés de canonització de fra Vicent Ferrer.

74 Els compromissaris reunits a Casp van enviar instruccions sobre la proclamació del veredicte als ambaixadors d'Aragó, Catalunya i València en llengua aragonesa, en llengua catalana i en «ydiomate valentino» respectivament (Ferrando 2013a: 396-397). En temps d'Alfons el Magnànim (1416-1458), la Cancelleria reial, en adreçar-se als diferents estats hispànics de la Corona d'Aragó, solia aclarir en les subcripcions de les missives en llatí que se'n trametia còpia en «llengua catalana» a Catalunya, València i Mallorca, i en «llengua aragonesa» al regne d'Aragó. Així, en la subscripció d'una carta en llatí, enviada des de Gaeta pel Alfons el Magnànim a la seua esposa, Maria de Castella, el 20 de juny de l'any 1443 (ACA, Cancelleria, reg. 2652, f. 53v), llegim: «Sub simili forma fuit scriptum officialibus infrascriptis [els governadors d'Aragó, Catalunya, Rosselló i Cerdanya, València, Oriola, Mallorca, Menorca i Eivissa i als virreis de Sardenya i Sicília] videlicet in Aragona in linga Aragonensi et aliis in linga Cathalana» (citat per Ferrando \& Nicolás 2011: 167). Tanmateix, se’n documenten algunes excepcions. Guillermo Tomás Faci ha tingut l'amabilitat de donarme notícia de dos documents cancellerescos en què es fa ús del nom de «llengua valenciana». El primer, de 22 de maig de 1438 (ACA, Cancelleria, reg. 2.584, ff. 79r-79v), és la lletra que Alfons el Magnànim envià, des de Càpua, a la seua esposa, la reina Maria, als seus germans, els infants Joan i Enric, i als governadors d'Aragó i de València, demanant-los que acceptessen el nomenament de Jaume Girard com a bisbe de Sogorb i Albarrassí. En la subscripció del document, redactat pel secretari reial català Arnau Fonolleda, es diu que «fuit scriptum sub dicta et proxime supra inserta forma gubernatoribus Aragonie et Valencie regnorum, scilicet, gubernatori Aragonie in linga aragonensi, et gubernatori Valencie in linga valentina». El segon document, de 21 de juny de 1443 (ACA, Cancelleria, reg. 2.652, ff. 54v-55r), és la missiva que Alfons el Magnànim trameté, des de Gaeta, als concejos de Saragossa, Terol, Calataiud, Tarassona i Osca i a les ciutats de València, Xàtiva, Oriola i Ciutat de Mallorques, donant-los compte de les negociacions de concòrdia amb el papa Eugeni IV. En la subscripció del document, redactat pel secretari reial valencià Joan Olzina, se'ns diu: «Sub simili forma fuit scriptum civitatibus regni Aragonum in linga aragonensi, et civitatibus regni Valencie in linga valentina». L'excepcionalitat de l'ús cancelleresc de «llengua valenciana» s'explica, en el primer cas, perquè afecta una diòcesi valenciano-aragonesa, $i$, en el segon cas, perquè no va adreçada alhora a les ciutats de Catalunya. Aquest ús de «llengua valenciana» en l'àmbit cancelleresc posa de manifest l'arrelament al regne de València del nom particular de la llengua i la sinonímia amb «llengua catalana», ja que la missiva en «llengua valenciana» també s'adreçà als «veguer, jurats e prohòmens de la Ciutat de Mallorques», on s’utilitzava el nom de «llengua catalana» (Mas 2020).

SCRIPTA, Revista internacional de literatura i cultura medieval i moderna, núm. 16 / desembre 2020 / pp. 71-130 ISSN: 2340-4841 · doi:10.7203/SCRIPTA.16.19213 
El nom de valencià no designava ni una llengua diferent de la catalana -els dos noms apareixen com a sinònims en diversos textos del segle XV, com ara les Regles d'esquivar vocables o mots grossers o pagesivols, atribuïble a Jeroni Pau- ni tampoc un dialecte geogràfic diferenciat dels dialectes de Catalunya -una visió que filològicament només seria acceptable a partir de l'edat moderna-, sinó simplement el nom popular -elevat a literari per Antoni Canals (1395) i a administratiu per Vicent Ferrer (1412) - amb què els valencians volien expressar els seus sentiments identitaris.

El català de principis del segle XV presentava bàsicament una petites diferències diatòpiques: el català de la zona oriental de Catalunya i de les illes Baleares tendia a confondre la $a$ i la $e$ àtones, a obrir la $e$ tònica tancada del llatí vulgar, a no articular la $i$ de la consonant palatal fricativa sorda generalment escrita $-x$ - en posició intervocàlica i -ix- en posició final de mot, a monoftongar els grups qua- / gua- en posició àtona i a preferir alguns mots, com mirall; en canvi, el català de la zona occidental de Catalunya i del regne de València distingia bé la a i la $e$ àtones, conservava la $e$ tònica tancada del llatí vulgar, articulava la $i$ de la consonant palatal fricativa sorda en totes les posicions, no solia monoftongar els grups qua- / gua- en posició àtona i preferia alguns mots, com espill. En el català occidental de València també s'adverteix la presència, generalment adaptada, d'alguns aragonesismes, com corder o mentira, usats per fra Vicent. Però aquestes diferències a penes transcendien a la llengua administrativa i literària. Només en els textos menys formals s'adverteixen les tendències fonètiques pròpies de qui els ha escrits. Així, al sermó predicat per mestre Vicent a Barcelona en honor de sant Domènec, copiat en el Ms. 477 de la Biblioteca de Catalunya (Perarnau 1985: 267-277), llegim grafies com bonas obras, axien, vexell, goria, coresma, i variants lèxiques com vertader, que reflecteixen trets preferits pel parlar de Barcelona, imputables al copista. Al sermó predicat per mestre Vicent a Tortosa el dia de la Pentecosta de 1413, copiat al mateix Ms. 477 (Perarnau 1985: 315-326), llegim grafies com reonable, gràcias, vexell, seguex, ayga i variats lèxiques com vertaders, alenda, gemegaren (mots o variants que, a excepció d'alenda, no són pròpies al segle XV del parlar de Tortosa), imputables al mateix copista. Un copista tortosí o valencià del mateix sermó hauria escrit raonable, gràcies, veixell, segueix, aygua, verdaders, alenda i gemecaren, respectivament, d'acord amb els trets del català occidental. Òbviament, és al copista catalano-oriental, probablement barceloní, i no a Vicent Ferrer, que cal atribuir la immensa majoria d'aquests trets, bàsicament fonètics.

Si jutgem pels sermons en llengua catalana, la llengua que fra Vicent emprava arreu de les terres catalanòfones era un català unitari amb algunes poques petges lèxiques valencianes. A València solia alternar les preferències lèxiques més generals i les més particulars: ausades / certes, anyell / corder, encepegar / entropessar, gemecar /gemegar, mentida / mentira, onso / ors (Schib 1977; Casanova 2008; Colomina 2021). Alguns d'aquests geosinònims predominantment, però no exclusivament, valencians, tenen a veure amb la influència aragonesa. El lèxic dels sermons predicats a Catalunya sol evitar la lleu coloració meridional que presenten els sermons predicats a València. La voluntat d'aproximació als seus auditoris explica la flexibilitat lingüística del nostre predicador. No hi ha cap document coetani que faça referència a la singularitat lingüística valenciana de fra Vicent, tot i que a finals de l'edat mitjana ja es podia reconéixer la procedència dels parlants de qualsevol regió de 
l’àmbit lingüístic català sobretot per la pronunciació (Ferrando \& Nicolás 2011: 103-105). Només s'hi documenta la doble denominació de la llengua.

Amb el propòsit d'homologar fra Vicent amb els apòstols, l'hagiografia vicentina més primerenca ja va transformar subtilment els seus usos ocasionals del català en la predicació a l'estranger a la categoria d'un ús universal. Ja hem vist que una lectura precipitada de les actes del procés de canonització ha convertit l'anècdota que reprodueix en català la frase «Digau en aquell dolent qui dorm sus la muralla que s'esvel le», adreçada per fra Vicent a un grup d'oients del seu sermó a Tolosa, en demostració que el català era la llengua general de la seua predicació i que tothom l'entenia. Ho fa fins i tot Gret Schib (1976: 334), quan remarca que, en les actes del procés, «quan citen literalment paraules del sant, [els testimonis] sempre les donen en català̀. En realitat, això se circumscriu pràcticament a les tres vegades en què, a les actes de canonització de Tolosa, és adduïda la mateixa anècdota, vinculada sens dubte amb la presència de catalanoparlants entre l'auditori.

Cal agrair la dedicació del medievalista Philip Daileader a l'estudi i comprensió de la vida i obra de mestre Vicent Ferrer. Les seues apreciacions, especialment en el tema de la llengua de la predicació del dominic valencià, exigeixen, però, algunes matisacions, ja que contradiuen algunes constatacions filològiques bàsiques i no tenen suficientment en compte la història social de la llengua catalana i la història de les mentalitats. Així, Daileader (2019 [2016]: 307), tot invocant el comentari de Schib sobre la tot just esmentada frase de mestre Vicent en català («Digau en aquell ...»), considera «probable que Vicent usara preferentment el dialecte valencià del català per tot arreu». ${ }^{75}$ Ara bé, la frase pretesament dita en «el dialecte valencià del català» es deia exactament igual a Catalunya $\mathrm{i}$ a Mallorca, i les paraules literals de Schib sobre la llengua de mestre Vicent remeten a les actes del procés, on es qualifica «la llengua del predicador de 'cathalonicum' o 'catholonicum'» (Schib 1976: 334). Schib no havia afirmat que fra Vicent s'expressés en un «dialecte valencià del català». De fet, no hi ha cap testimoni del procés de canonització ni cap document que puga suggerir que fra Vicent usava el «dialecte valencià del català».

75 No hi havia cap «dialecte valencià del català». Les quatre modalitats actuals de la llengua catalana (la catalanooccidental, la catalano-oriental, la valenciana i la balear) es reduien al segle XV pràcticament a dues, l'occidental i l'oriental. Així, des del punt de vista lingüístic, les diferències entre el parlar de Lleida i el de València, principals ciutats del català occidental, eren mínimes, però els habitants del regne de València i, de manera especial, els de la capital del regne, per raons identitàries, solien designar la seua llengua popularment amb el nom de valencià. Eren més cridaneres les poques diferències entre, posem per cas, el parlar de Barcelona i el de la Ciutat de Mallorca, principals ciutats del català oriental, però en aquest cas els habitants de la Ciutat i de l'illa de Mallorca continuaven designant la seua llengua amb el nom de català, tal com ha posat de manifest recentment Antoni Mas (2020). En temps moderns, les petites diferències diatòpiques del temps de mestre Vicent Ferrer s'han accentuat, però les estuctures bàsiques de la llengua compartida per valencians, catalans i baleàrics s'han mantingut, a pesar de segles de marginació i discriminació a partir del segle XVI. Tanmateix, des d'aquesta època, el do de llengües de fra Vicent Ferrer ha estat invocat al País Valencià, compensatòriament, com un signe d'exaltació d'una «llengua valenciana» privativa, que el sant hauria usat sempre (Ferrando 2019). 
En parlar de les enquestes bretones, Daileader (2019: 310) també sosté que «els testimonis bretons simplement van manifestar que els oients que no entenien francés, o francés o valencià o català -és a dir, gent que no entenia les llengües romàniques-, entenien Vicent, que no és el mateix que afirmar [com fa Ferrando] que Vicent predicara en francés». Doncs bé, llegides totes les actes de la part bretona del procés i adduïdes més amunt les declaracions dels testimonis que es pronuncien sobre la llengua de la predicació de fra Vicent, es constata que en aquestes no es parla mai de «valencià o català», com afirma Daileader, sinó de «català» o de «vulgar d'Aragó», i no es contraposa mai català a valencià.

Els testimonis bretons es reparteixen bàsicament entre els qui deien que, tot i ignorar el francés, entenien fra Vicent i els qui deien que aquest alternava el francés i el català. En canvi, Daileader deixa entendre que, no afirmant directament cap testimoni que el nostre predicador s'expressava en francés, ho hauria fet en el «dialecte valencià del català». La interpretació més racional i natural és que, si els bretons britonizantes (els monolingües) deien que no entenien fra Vicent perquè ignoraven el francés, és perquè aquest hi predicava en francés. Ho reconeixen fins i tot dos dels hagiògrafs vicentins més prestigiosos, els pares José María de Garganta i Vicente Forcada (1956: 41-43), quan constaten que, a la Bretanya, fra Vicent Ferrer recorria la francés «por lo menos en algunos sermones». D'altra banda, les respostes dels testimonis que afirmaven que fra Vicent alternava el francés i el català confirmen que aquest predicava, segons ells parcialment, en francés. Si, més enllà dels gestos de fra Vicent, aquests testimonis britoniz̨antes haguessen comprés el català, no haurien tingut necessitat de recórrer a persones bilingües per a conéixer el contingut concret de les predicacions de fra Vicent. De fet, aquests testimonis no fan sinó confirmar que el francés era el vehicle habitual de la seua predicació.

Mirant el conjunt de les declaracions bretones, sembla evident que els testimonis que afirmaven que fra Vicent alternava el francés i el català perseguien convertir en miracle la comprensió d'alguna possible expressió ocasional en català, tal com s'havia propalat des de Tolosa. Els bretons difícilment podrien saber que el dominic valencià els predicava en «català» o en el «vulgar d'Aragó», si no se'ls deia que usava aquesta llengua, altrament desconeguda. I si fra Vicent, predicant en el «dialecte valencià del català», era entés per tothom, no s'explica per què fra Vicent evità no sols la Bretanya monolingüe en bretó, sinó també endinsar-se en terres europees de llengua no romànica.

El mateix medievalista nord-americà (2019: 307) afirma que Martín d'Alpartil «va veure el dominic [valencià] predicar a Gènova i informà que allà predicà en valencià». En canvi, el que diu la crònica d'Alpartil és que fra Vicent «vix fi[n] geret ling[u]am Valentinam», és a dir, que, per a fer-se entendre, 'a penes deformava la llengua valenciana'. Per tant, havia de fer-hi algunes adaptacions lingüístiques. El testimoni d'Alpartil contradiu el de Clamanges (1405), més amunt adduï, que afirma que mestre Vicent va predicar a Gènova en un italià excel lent. En realitat, les deformacions del valencià enginyades per fra Vicent haurien consistit a aproximar-se a l'italià. No cal dir que la interpretació d'Alpartil, escrita en la quarta dècada del segle XV, és una versió contaminada per l’operació mitificadora de fra Vicent. Daileader obvia els subterfugis lingüístics d'Alpartil.

SCRIPTA, Revista internacional de literatura i cultura medieval i moderna, núm. 16 / desembre 2020 / pp. 71-130 ISSN: 2340-4841 ·doi:10.7203/SCRIPTA.16.19213 
Ja hem vist que Daileader (2019: 310) considera «probable que Vicent usara preferentment el dialecte valencià del català per tot arreu, i que hi afegira paraules o expressions de la llengua vernacla local, sobretot quan imitava diàlegs». No hi ha cap document que prove que fra Vicent prediqués habitualment en català fora de l'àmbit lingüístic català. El silenci sobre l'ús del català en la predicació castellana de fra Vicent és aclaparador. El testimoni de Clamanges sobre l'ús de l'italià a Gènova en vida de fra Vicent deixa pocs dubtes sobre la llengua en què predicà. Les declaracions testificals dels bretons, preses en conjunt, posen de manifest que la llengua instrumental de la predicació de fra Vicent a la Bretanya romànica i bilingüe, és a dir, allà on podia ser entés, era el francés.

El mateix professor (2019:309) també afirma que «el desig d'atribuir a Vicent qualitats miraculoses posa de manifest tant el seu multilingüisme com el seu Valencian] $^{76}$ monolingüisme». Admet, per tant, que fra Vicent coneixia les diverses llengües vernacles locals, però no aporta proves de la hipòtesi diglòssica que sosté: utilitzaria arreu el «dialecte valencià del català» com a llengua formal de l'exposició del sermó (doctrina, moral) i reservaria les diverses llengües locals dels països que recorria (el castellà, l'aragonés, el francés, l'occità i l'italià) com a registre informal per als diàlegs dels exempla. Crec que les expressions col loquials en català dels sermons predicats a Múrcia que llegim al manuscrit de Patriarca o l'observació de Clamanges que fra Vicent a Gènova predicava en un italià acurat no semblen avalar aqueixa visió dicotòmica, que en tot cas es donava entre el llatí i el romanç. El teòric monolingüisme valencià de fra Vicent, compatible amb una comprensió universal dels seus sermons, és contradit per la praxi lingüística del nostre predicador, que sempre procurà aproximar-se lingüísticament a l'auditori.

Daileader no aporta documentació per a recolzar la hipòtesi que mestre Vicentusaria «preferentment el dialecte valencià del català per tot arreu», ni justifica en què consistiria el «dialecte valencià del català». La consideració del «dialecte valencià del català» entra en contradicció amb la seua opinió que en els sermons castellans «apareixen paraules i expressions valencianes i catalanes». Daileader (2019: 308) no ens diu quines són les diferències entre les paraules i expressions valencianes $i$ les paraules i expressions catalanes, ni n'addueix cap exemple. En les enquestes del procés de canonització no apareix mai ailladament la denominació de «valencià» o de «llengua valenciana» i, les quatre vegades en què apareix, sempre ho fa dins del sintagma «llengua catalana o valenciana» $\mathrm{o}$ viceversa, i per tant sempre com a sinònims.

En conseqüència, trobe difícilment assumibles les interpretacions de Daileader, que, en aquests aspectes, s'ajusten poc a la crítica històrica i textual i no gens a la filologia romànica.

76 És el que posa la versió anglesa original (Daileader 2016: 198).

SCRIPTA, Revista internacional de literatura i cultura medieval i moderna, núm. 16 / desembre 2020 / pp. 71-130 ISSN: 2340-4841 · doi:10.7203/SCRIPTA.16.19213 


\section{A tall de conclusió}

L'examen crític dels sermonaris de mestre Vicent i de les enquestes del seu procés de canonització permeten concloure que el dominicà valencià predicà en una llengua catalana comuna arreu de València, Catalunya i Mallorca i que tendí a alternar els trets generals i les preferències locals de la llengua en l'àmbit territorial valencià. Fora dels territoris de llengua catalana, fra Vicent utilitzà els seus coneixements d'aragonés, castellà, occità, francés i italià per a adreçar-se als auditoris respectius, independentment que pogués esquitxar, deliberadament o no, els seus sermons amb alguna paraula o expressió catalana o fins i tot d'una altra llengua.

A pesar de la complexitat textual de la transmissió dels sermons vicentins, la profusió, la comparació i l'anàlisi crítica de les nombroses dades lingüístiques que aporten els sermonaris primitius ajuden a determinar que mestre Vicent, políglota com era, s'adaptava tan bé com sabia i podia a la llengua de la majoria de la seua audiència i que procurava conéixer-la. L'anàlisi lingüística de les reportacions i dels manuscrits quatrecentistes de la predicació de fra Vicent, tant hispànics com centreeuropeus, certifica que els al loglotismes que s'hi observen són generalment fruit del treball de consulta de dos o més antígrafs o mera collita dels copistes, però també, alhora, demostració fefaent del poliglotisme de mestre Vicent Ferrer.

La identificació de la predicació de fra Vicent en terres aragoneses entre juliol i setembre de 1412, amb un mínim de 35 sermons, i la ubicació aragonesa del famós sermó adreçat als habitants de la Serrania, que he aportat, compensa mínimament l'absència d'informació que teníem sobre la important predicació aragonesa de fra Vicent i ajuda a completar la cronologia i l'itinerari de la seua tasca missional en la Corona d'Aragó i a interpretar correctament la frase al lusiva al parlar serrà.

La «fama pública» que mestre Vicent, predicant en la seua llengua era entés per tothom, és un discurs interessat, induït per la institució eclesiàstica i assumit per unes religiositat medieval crèdula, que es construí progressivament en pro de l'elevació de fra Vicent als altars i de la seua homologació amb els apòstols. De fet, la predicació universal en la «sua valentina ac materna lingua», que li atribuí el seu biògraf Pietro Ranzano, no és avalada per la butla de canonització de fra Vicent, publicada pel papa Pius II, de 1458 (Esponera 2018: 574).

El veritable miracle de mestre Vicent no és que prediqués pertot arreu en la seua llengua materna, sinó que tothom avalava la creença que era entés com si els hagués parlat en la llengua de cadascú. Tal era el poder d'atracció de la gestualitat vicentina, com reconeixen molts testimonis de procés de canonització! I tal fou el plantejament canònic del suposat miracle del do de llengües. 


\section{Bibliografia}

Almela i Vives, Francesc (1927) Sant Vicent Ferrer, Barcelona, Barcino.

Alpartil, Martinus (1906) Chronica actitatorum temporibus domini Benedicti XIII, Franz Ehrle (ed.), Paderborn, Druck und Verlag von Ferdinand Schöningh.

Brunel, Claude (1924) «Un plan de sermon de Saint Vincent Ferrier», Bibliothèque de l'Ecole des Chartes, 85, pp. 110-117.

—. (1934) «Notice et extrait du manuscrit 1095 de la Bibliothèque de Marseille contenant des sermons catalans», Bibliothèque de l'École des Chartes, XCV, pp. 5-30.

_- (1953) «Le sermon en langue vulgaire prononcé à Toulouse par Saint Vincent Ferrier le Vendredi Saint 1416», Bibliothèque de l'École des Chartes, CXI, pp. 5-53.

Cappelli, Adriano (1930) Cronologia, cronografia e calendario perpetuo, Milà, Ulrico Hoepli.

Casanova, Emili (2008) «La diversitat lingüística dels sermons de Sant Vicent», dins Emili Casanova \& Jaume Buigues (eds.), En el món de sant Vicent Ferrer, Teulada/València, Ajuntament de Teulada, pp. 27-50.

Cátedra, Pedro Manuel (1984) «La predicación castellana de san Vicente Ferrer», Boletín de la Real Academia de Buenas Letras, XXXIX (1983-1984), pp. 235-309.

(1994) Sermón, sociedad y literatura en la Edad Media. San Vicente Ferrer en Castilla (1411-1412), Valladolid, Junta de Castilla y León.

Chabás, Roque (1902-1903) Estudio de los sermones valencianos de san Vicente Ferrer. Madrid, Tipografía de la Revista de Archivos, Bibliotecas y Museos.

Colomina, Jordi (2019) «La llengua dels sermons de sant Vicent Ferrer», Revista Valenciana de Filologia, 3, pp. 103-125.

- (2021) La llengua dels sermons de sant Vicent Ferrer. I. Estudi lingüistic, i II. Diccionari integral, València, Acadèmia Valenciana de la Llengua.

Compagna, Anna Maria (2019) «Sobre els passos de sant Vicent Ferrer al Regne de Nàpols i Sicília», Revista Valenciana de Filologia, 3, pp. 127-138.

Concina, Chiara (2019) «La presència de Vicent Ferrer a Itàlia del nord: la Vita transmesa pel ms. XXVII de l'Arxiu Històric Diocesà de Novara», Revista Valenciana de Filologia, 3, pp. 139-158.

Daileader, Philip (2019 [2016]) La vida i el món de sant Vicent Ferrer, València, Acadèmia Valenciana de la Llengua / Publicacions de la Universitat de València.

Diago, Francisco (1600) Historia de la vida, milagros, muerte y discipulos del bienaventurado predicador apostólico valencinao S. Vincente Ferrer, (...) compuesta por el presentado F. Fr. Francisco Diago, de la propia nación y orden, Barcelona, Emprenta de Gabriel Graells y Giraldo Dotil. 
Esponera, Alfonso (ed.) (2018) Proceso de canonizaación del maestro Vicente Ferrer O. P., València/Friburg, Facultad de Teología San Vicente Ferrer/Studia Friburgensia.

Eubel, Conradum (1913) Hierarchia catholica Medii Aevi, Münster, Libraria Regensbergiana.

Fàbregas, Immaculada (2019) «Sant Vicent Ferrer a la Bretanya: de l’infern al paradís a través de la missa de Kernascléden», Revista Valenciana de Filologia, 3, pp. 159-182.

Ferrando, Antoni (1980) Consciència idiomàtica i nacional dels valencians, València, Institut de Filologia Valenciana. - (1989) «La formació històrica del valencià», dins A. Ferrando (ed.), Segon Congrés Internacional de la Llengua Catalana, VIII, Àrea 7. Història de la Llengua, València, Institut de Filologia Valenciana, pp. 398-428

- (1997) «Vicent Ferrer (1350-1419), predicador políglota de l'Europa occidental», dins Paradigmes de la història. I. Actes del Congrés "Sant Vicent Ferrer i el seu temps" (València, 13-16 maig, 1996), València, Editorial Saó, pp. 71-95.

—_. (2012) «Sant Vicent Ferrer: do de llengües, do de gents», Saó, 369 (març), pp. 16-18.

—_. (2013a) «Llengua, nació i territori al regne de València em temps de sant Vicent Ferrer (ca. 1350-1419)»: l'escenificació lingüística al Compromís de Casp», dins Ricard Bellveser (coord.), Els valencians en el Compromís de Caspi i en el Cisma d'Occident, València, Institució Alfons el Magnànim, pp. 373-402.

- (2013b) Sant Vicent Ferrer en la historiografia, l'hagiografia i l'espiritualitat al segle XV, València, Institució Alfons el Magnànim.

- (2019) «La multisecular invocació de sant Vicent Ferrer com a defensor de la 'llengua valenciana'», Revista Valenciana de Filologia, 3, pp. 183-239.

Ferrando, Antoni \& Nicolàs, Miquel (2011) Història de la llengua catalana. Barcelona, Editorial UOC.

Fuster, Joan (1968 [1955]) «L'oratòria de sant Vicent Ferren», dins Obres completes, I, Barcelona, Edicions 62, pp. 23-151.

García Martínez, Antonio Claret (2006) La escritura transformada. Oralidady cultura escrita en la predicación de los siglos XV al XVII, Huelva, Publicaciones de la Universidad de Huelva.

Garganta, José María \& Forcada, Vicente (1956) Biografía y escritos de san Vicente Ferrer, Madrid, Biblioteca de Autores Cristianos.

Giralt, Javier \& Nagore, Francho (eds.) (2020) Aragonés y catalán en la bistoria lingüística de Aragón, Saragossa, Prensas de la Universidad de Zaragoza.

Gimeno Blay, Francisco (1992) La Biblia de san Vicente Ferrer (Códice manuscrito del siglo XIII), València, Scriptorium, Ediciones Limitadas.

- (2002) «Sermonario de San Vicente Ferrer del Real Colegio-Seminario de Corpus Christi de Valencia», Dominican History Newsletter (Roma), XI (2002), pp. 255-264. 
Gimeno Blay, Francisco (2013) Una corona, set aspirants. Casp 1412, València, Institució Alfons el Magnànim.

- (2019) «Modelos de transmisión textual de los sermones de san Vicente Ferrer: la tradición manuscrita», Anuario de Estudios Medievales, 49/1 (enero-junio), pp. 137-169.

Gimeno, Francisco \& Mandingorra, María Luz (eds.) (2002): Sermonario de san Vicente Ferrer del Real Colegio-Seminario del Corpus Christi de Valencia, València, Ajuntament de València.

(eds.) (2006) Sermonario de Perugia (Convento dei Domenicani, ms. 477). Edición crítica e introducción,València, Ajuntament de València.

—- (eds.) (2009) San Vicente Ferrer. Sermones de Cuaresma en Suiza, 1404 (Couvent des Cordeliers, ms. 62). Edición crítica e introducción, València, Ajuntament de València.

. (eds.) (2019) Sermonario de Aviñón (Avignon. Bibliothèque Municipale ms 610). Introducción, edición y notas a cargo de F. Gimeno y M. L. Mandingorra, València, Universitat de València.

Gorce, Mathieu-Maxime (1924) Saint Vincent Ferrier (1350-1419), París, Librairie Plon.

Le Dorze, Jean (2011) Tras los pasos de san Vicente Ferrer, València, RomEditors.

López, Carlos (ed.) Epistolari de Ferran I d'Antequera amb els infants d'Aragó i la reina Elionor, València, Universitat de València.

Martínez Ferrando, Jesús Ernest (1952) El nostre sant Vicent Ferrer, València, Editorial Torre.

Martines Peres, Vicent (2012) «Aspectos de la poliédrica influencia de los clásicos. Nuevas imágenes clave de la influencia de san Vicente Ferrer en Italia», eHumanista, 22, pp. 582-595.

Martínez Romero, Tomàs (2002) Aproximació als sermons de sant Vicent Ferrer, Paiporta, Denes.

—_. (2019) «Sobre la reportació de la Quaresma de 1413 i altres qüestions complementàries», Anuario de Estudios Medievales, $49 / 1$ (enero-junio), pp. 215-241.

Mas, Antoni (2020) Llengua, terra, pàtria i nació. L'evolució de la consciència lingüistica i etnocultural entre els cristians de l'illa de Mallorca (segles XIV-XVII), Palma de Mallorca, Documenta Balear.

Menjot, Denis (1975) «L'immigration à Murcie et dans son territoire sous les premiers Trastamares (1370-1420)», Revue d'bistoire économique et sociale, 53, pp. 216-265.

Miralles, Melcior (2011) Crònica i dietari del capellà d'Alfons el Magnànim, Mateu Rodrigo (ed.), València, Universitat de València.

Morenzoni, Franco (2004) «La prédication de Vincent Ferrier à Montpellier en décembre 1408», Archivum Fratrum Praedicatorum, 74, pp. 225-272.

Morenzoni, Franco (2008) «Les prédicateurs et leurs langues à la fin du Moyen Âge», Peter von Moos (ed.), Zwischen Babel und Pfingsten / Entre Babel et Pentecôte. Sprachdifferenžen und Gesprächsverständigung in der Vormoderne (8.-16 Jో.), Münster/Zürich, Lit, pp. 501-518. 
Perarnau, Josep (1984) «L'antic ms. 279 de la Catedral de València, amb sermons de sant Vicent Ferrer, perdut durant la guerra 1936-1939. Intent de reconstrucció», Butlletí de la Biblioteca de Catalunya, 10 (1982-84), pp. 29-44.

- (1985) «La compilació de sermons de sant Vicent Ferrer de Barcelona, Biblioteca de Catalunya, Ms. 477», Arxin de Textos Catalans Antics, 4, pp. 213-402.

Perarnau, Josep (1996) «Els quatre sermons catalans de sant Vicent Ferrer en el manuscrit 476 de la Biblioteca de Catalunya», Arxiu de Textos Catalans Antics, 15, pp. 109-340.

—_. (1999a) «Les primeres 'reportationes' de sermons de St. Vicent Ferrer: les de Friedrich vom Amberg, Fribourg, Cordeliers, ms 62, Arxiu de Textos Catalans Antics, 18, pp. 63-155.

—. (1999b) «Aportació a un inventari de sermons de sant Vicent Ferrer: temes bíblics, títols i divisions esquemàtiques», Arxiu de Textos Catalans Antics, 18, pp. 479-811.

—. (1999c) «Els manuscrits d'esquemes i de notes de sermons de sant Vicent Ferrer», Arxiu de Textos Catalans Antics, 18, pp. 157-398.

—_. (1999d) «Sobre el manuscrit de València, Col legi del Patriarca, amb sermons de sant Vicent Ferrer», Arxiu de Textos Catalans Antics, 18, pp. 399-453.

Ferrer», Arxiu de Textos Catalans Antics, 18, pp. 455-477.

—. (1999f) «Cent anys d'estudis dedicats als sermons de sant Vicent Ferren», Arxiu de Textos Catalans Antics, 18, pp. 9-62.

—_. (1999g) recensió a A. Ferrando, «Vicent Ferrer, predicador políglota de l'Europa occidental», dins Actes del Congrés "Sant Vicent Ferrer i el seu temps" (València, 13-16 maig, 1996) (València, 1997), Arxiu de Textos Catalans Antics, 18, p. 1030.

- (2003) «La (darrera) quaresma transmesa de sant Vicent Ferrer. Clermont-Ferrand, BMI, Ms. 45», Arxiu de Textos Catalans Antics, 22, pp. 343-350.

Riera, Manuel (2007) «Mestres d'art i medicina, els pretors dels remeis i doctors en medicina», Gimbernat, 47, pp. 39-71.

Riera, Jaume (2013) «Itinerari peninsular de mestre Vicent Ferren», dins R. Bellveser (coord.), Els valencians en el Compromís de Casp i en el Cisma d'Occident, València, Institució Alfons el Magnànim, pp. 403-457.

Riquer, Martí de (1964a) «Fecha y localización de algunos sermones de san Vicente Ferrer», Boletín de la Real Academia de Buenas Letras de Barcelona, XXX (1963-1964), pp. 151-168.

—. (1964b) Història de la literatura catalana, vol. II, Barcelona, Ariel.

Robles Sierra, Adolfo (ed.) (1995) San Vicente Ferrer. Colección de Sermones de Cuaresma y otros según el Manuscrito de Ayora, València, Ajuntament de València. 
Rodrigo, Mateu (ed.) (1985) Les Corts generals de Jerusalem. Sermó al legòric del segle XIV, Barcelona, Edicions del Mall.

—. (2013) Diplomatari de la Unió del Regne de València (1347-1349), València, Universitat de València.

_- (2016) «La llibreria del canonge Guillem Serra i el seu llegat a la Catedral de València (1489)», Butlletí de la Reial Acadèmia de Bones Lletres de Barcelona, LIV (2013-2014), pp. 137-204.

Rosselló Verger, Vicent M. (2018) «L'itinerari missioner de sant Vicent Ferrer a Mallorca (1431414)», Quadernos de Geografía, 100, pp. 5-22.

Sanchis Guarner, Manuel (1973) «Estudi preliminar» a Sant Vicent Ferrer, Sermons de Quaresma, volum I, València, Albatros, pp. 7-38.

Sanchis Guarner, Manuel (1974) «Sobre el do de llengües atribuït a sant Vicent Ferrer», Las Provincias, 21-IV-1974.

Sanchis Sivera, Josep (1927) Quaresma de sant Vicent Ferrer predicada a València l'any 1413, Barcelona, Institució Patxot.

—_. (1932-1934) Sant Vicent Ferrer, Sermons, volums I-II, Barcelona, Editorial Barcino.

Schib, Gret (ed.) (1975-1984) Sant Vicent Ferrer, Sermons, volums III (1975), IV (1977), V (1984) i VI (1988), Barcelona, Editorial Barcino.

—_. (1976) «Els sermons de sant Vicent Ferren», dins Actes del III Col loqui Internacional de Llengua i Literatura Catalanes, Oxford, The Dolphin Book, pp. 325-336.

—. (1977) Vocabulari de sant Vicent Ferrer, Barcelona, Fundació Salvador Vives Casajuana.

Stich, Dominique (2005) «El francoprovençal: tercer domini gal loromànic entre la llengua d'oc i la llengua d'oïl», Anuari de l'Agrupació Borrianenca de Cultura, XVI, pp. 173-191.

Tomás, Guillermo (2020) El aragonés medieval. Lengua y Estado en el reino de Aragón, Saragossa, Prensas de la Universidad de Zaragoza. 